Portland State University

PDXScholar

Spring 6-2-2016

\title{
Gritos en el Desierto: Denuncia y Resistencia en las Obras de las Escritoras Wayuu Estercilia Simanca Pushaina y Vicenta María Siosi Pino
}

Lindsay H. Perwak

Portland State University

Follow this and additional works at: https://pdxscholar.library.pdx.edu/open_access_etds

Part of the Latin American Languages and Societies Commons, and the Latin American Literature Commons

Let us know how access to this document benefits you.

\section{Recommended Citation}

Perwak, Lindsay H., "Gritos en el Desierto: Denuncia y Resistencia en las Obras de las Escritoras Wayuu Estercilia Simanca Pushaina y Vicenta María Siosi Pino" (2016). Dissertations and Theses. Paper 3001. https://doi.org/10.15760/etd.3002

This Thesis is brought to you for free and open access. It has been accepted for inclusion in Dissertations and Theses by an authorized administrator of PDXScholar. Please contact us if we can make this document more accessible: pdxscholar@pdx.edu. 
Gritos en el desierto: Denuncia y resistencia en las obras de las escritoras Wayuu

Estercilia Simanca Pushaina y Vicenta María Siosi Pino

by

Lindsay H. Perwak

A thesis submitted in partial fulfillment of the requirements for the degree of

\author{
Master of Arts \\ in \\ Spanish
}

Thesis Committee:

Enrique E. Cortez, Chair

Cynthia A. Sloan

Elena Avilés

Portland State University

June 2016 
(C) 2016 Lindsay H. Perwak 


\begin{abstract}
The way we read and interpret literature is frequently influenced by factors that operate beyond the scope of the average reader's awareness. In this thesis, selected works by two Wayuu writers, Estercilia Simanca Pushaina and Vicenta María Siosi Pino, are analyzed and interpreted in an attempt to unveil some of these behind-the-scenes agents and issues, as well as explore how the stories' classification in the children's literature genre reveals a deep-rooted colonial tendency to infantilize indigenous individuals in contemporary Colombia.
\end{abstract}

Despite the fact that the two authors, both mestizo women who self-identify with the Wayuu indigenous group of northern Colombia, prefer to write short stories that highlight the child and adolescent experience, the implicit themes and the complexity of their texts reject the "children's story" label that has been imposed on their literature. Furthermore, this thesis discusses how the two authors utilize the colonial trope of the Indian-as-child to their advantage by capsizing the imagery, thus rejecting the original power of the symbol and claiming it as their own.

The first section of this investigation provides certain contextual specifics related to the cultural and social environment of the Wayuu indigenous group, particularly regarding that experienced by women. The second chapter includes an explanation of the impact a book's genre and its "paratext" may have on the reception and interpretation of these texts, and additionally proposes that the colonial practice of infantilizing indigenous people appears in both the assignment of genre as well as in several extratextual elements surrounding the stories. Chapter three offers an in-depth analysis of five selected pieces of the Wayuu authors' writing and explores how the texts may be read on multiple levels. 
This close reading reveals several examples of overt criticism towards the hegemonic society as well as displays instances of a more subtle rebellion; both explicit and implicit messages effectively expose and protest the current conditions of abuse, oppression and injustice that continue to anguish the Wayuu people. 


\section{Agradecimientos}

Ante todo, quiero agradecerle a mi familia, cuyo apoyo ha sido esencial durante tantos años de desarrollo personal, emocional y académico. A mi madre, hermosa mujer, que siempre me ha hecho confiar en que todo va bien inclusive cuando voy por el mal camino. Gracias por dejarme descubrir el mundo por mis propios impulsos y locuras. A mi papá, mi héroe desde siempre. A mi esposo Carl, querido amor de mi vida, gracias por aguantarme durante estos años de trabajo, tareas, clases, tesis... en fin. Merecemos unas vacaciones definitivamente. Vamos a explorar todas esas montañas y valles hasta que lloremos de su majestuosidad.

Al director de esta tesis, mi estimado consejero y profesor Enrique Cortez: tú siempre has sido la persona que me ha hecho creer que todo esto es posible. Desde la primera reunión en la cual me dijiste que una tesis no era más que esto más el otro más unos detallitos más... y ya está. Claro, ha sido algo más complicado pero vaya sorpresa; tenías razón y yo seguramente necesitaba que me dijeras eso para poder emprender este proyecto. Te agradezco profundamente por apoyarme incansablemente en este proceso y por brindarme siempre tus palabras de crítica, elogio y ánimo. A Cynthia Sloan y Elena Avilés, mil gracias por sus comentarios, sugerencias y dirección a lo largo de este proyecto. Ustedes dos me han inspirado a pensar, repensar y aclarar todo hasta los detallitos. No hubiera podido imaginar ni inventar un comité mejor que ustedes tres.

A Estercilia Simanca Pushaina y Miguel Rocha Vivas, quienes desde lejos me ayudaron generosamente a desarrollar y profundizar este trabajo. Nunca había pensado que iba a 
ser posible hablar con la autora misma mientras analizara su obra, ni que usted, Miguel, iba a ser tan amable de querer comunicarse conmigo desde Colombia. Gracias por sus aportes y valiosas sugerencias: ambos me han honrado con su participación directa en este proyecto.

A la familia Chipiaje: Abel, mi maestro. Magdalena, mi madre. Ama, Keila, María Camila, mis hermanas. Todo esto ha sido posible gracias a ustedes; porque un día los conocí en Masinga, y nunca me han soltado, inclusive cuando nos separaron miles de kilómetros. No saben cuánto les estimo, aprecio y quiero a todos ustedes. Pronto regresaré a esa tierra sagrada, fuente que inspiró todo este trabajo.

A los Wayuu: gracias por iluminar este trabajo. Me han ofrecido tantas ideas y nuevas perspectivas, junto a múltiples ejemplos de su arte a través de sus escritores. Espero que esta tesis haya podido revelar algunos aspectos de su cultura, tan profunda y dinámica.

Finalmente, quiero agradecerles a mis compañeros del programa de Masters de PSU sobre todo a Christopher McCauley y Gloria Trujillo, tan chiflados como yo. Gracias por acompañarme en este viaje. 


\section{Tabla de contenido}

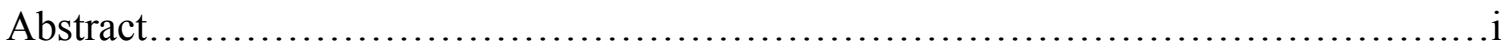

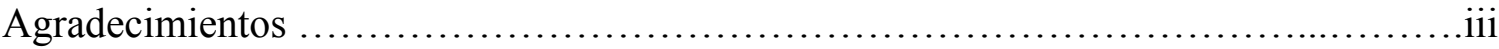

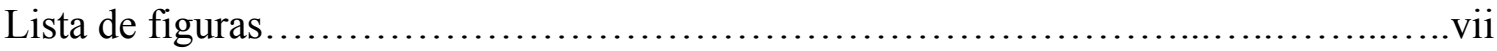

\section{Capítulo 1}

Introducción

1

1.1 Breve contexto histórico...................................................

1.2 Contexto cultural: Los Wayuu............................................ 10

1.3 Contexto literario: La expresión Wayuu y su alcance..........................21

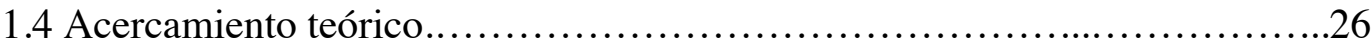

\section{Capítulo 2}

Literatura infantil y escritura Wayuu..................................................

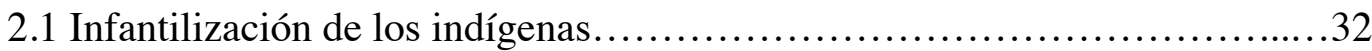

2.2 El género literario y el rol de los "mediadores artísticos"......................36

2.3 Interpretación de paratextos...........................................40

2.4 Realidades de un mercado restringido..................................48

\section{Capítulo 3}

Análisis textual: Denuncia e intentos de reconciliación................................52

3.1 Críticas abiertas ..........................................................

3.2 Cuestionamiento de los valores de la cultura dominante....................69

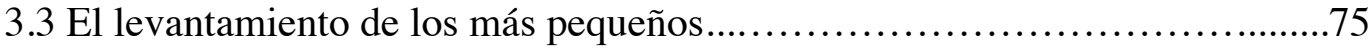

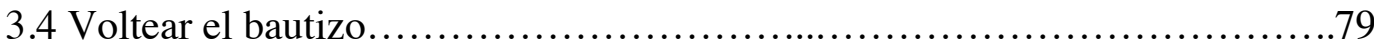




\section{Capítulo 4}

A modo de conclusión.

Obras citadas

\section{Apéndices}

A. Entrevistas personales con Estercilia Simanca Pushaina.....................100

B. Carta de Vicenta Siosi Pino al presidente Santos............................105 


\section{Lista de figuras}

Figura 1:

Mapa de resguardos indígenas en Colombia....................................10

Figura 2:

Nombres de unos clanes Wayuu con su animal totémico y símbolo asociado..............19

Figura 3:

Contraportada de la antología Pütchi Biyá Uai II, un "libro al viento"....

Figura 4:

Portada infantil del libro El encierro de una pequeña doncella...........................41

Figura 5:

Portada del cuento "Manifiesta no saber firmar. Nacido: 31 de diciembre" .............42

Figura 6:

Ilustración que acompaña al cuento "No he vuelto a escuchar los pájaros"....

Figura 7:

Ilustración que acompaña al cuento "La señora iguana".

Figura 8:

Portada del libro El dulce corazón de los piel cobriza .................................51 


\section{Capítulo 1 \\ Introducción}

El presente trabajo se enfoca en el estudio y análisis crítico de una selección de obras escritas por dos autoras contemporáneas colombianas de origen indígena Wayuu, Estercilia Simanca Pushaina y Vicenta María Siosi Pino. Las dos escritoras son mejor conocidas por sus cuentos cortos, la mayoría de los cuales han sido encasillados como cuentos infantiles a pesar de contener una temática compleja y relevante para la población adulta. Una de las preguntas fundamentales que exploraré a lo largo de esta tesis es evaluar si el sistema literario colombiano y el público, por extensión, están preparados para aceptar los escritos de estas escritoras como literatura de alta estimación o si estos textos circulan, como la clasificación de género parece señalar, como meros cuentos didácticos, agradables y aptos para niños. La hipótesis de este trabajo afirma que la clasificación infantil de los cuentos de Simanca Pushaina y Siosi Pino es tendenciosamente aplicada en su mayor parte a los escritos de las dos escritoras indígenas. Tanto la temática como la complejidad de los mensajes implícitos en los cuentos de ambas escritoras rechazan la etiqueta infantil que se ha adherido a sus obras literarias en su totalidad. Sin embargo, la categorización específica en el género infantil/juvenil paralelamente ofrece a estas escritoras una oportunidad única de protestar sobre la condición actual de los indígenas en Colombia, en particular de las mujeres Wayuu.

A través de personajes infantiles, Simanca Pushaina y Siosi Pino aprovechan de la visión de la niñez para proporcionar a sus cuentos una perspectiva de inocencia; esta perspectiva no quiere decir que retrata una visión idealizada sino una más despejada, sin 
los prejuicios ni las expectativas que suelen manchar la perspectiva adulta. Dicha estrategia permite a los lectores, sean niños o adultos, desarrollar preguntas de carácter sencillo pero igualmente esencial. Estas preguntas básicas de los personajes infantiles, en las cuales casi siempre plantean el por qué o el por qué no de alguna situación, práctica o comportamiento, figuran entre las más relevantes en el intento de establecer una realidad intercultural y multiétnica en la cual los indígenas puedan incorporarse activamente y dignamente en la sociedad hegemónica. Tales consideraciones y meditaciones de los personajes infantiles representan el inicio de un proceso hacia una posible resolución de conflictos entre los indígenas y el Estado colombiano/cultura dominante y un abordaje de cierta problemática que padecen muchos grupos indígenas (pobreza, desplazamiento, escaso acceso a servicios médicos, falta de recursos esenciales, malnutrición, oportunidades limitadas para la educación, pérdida de identidad cultural y/o idioma nativo, etc.). Para Simanca Pushaina, las preguntas y los comentarios de sus personajes infantiles son inocentes y asimismo los más obvios; opina que los mayores típicamente ya no son capaces de formular estas reflexiones que se desarrollan tan fácilmente en el intelecto de los niños (entrevista personal). ${ }^{1}$ En ciertas formas, Simanca Pushaina y Siosi Pino absorben la infantilización de los indígenas-la imagen del indígena como niño ha sido impuesta a las poblaciones nativas desde la época colonial-, la inviertan y la reubican en un nuevo contexto. Con esta inversión de un tropo colonial, las dos escritoras logran convertirlo en su propia herramienta de denuncia y crítica social.

El tema de la infantilización del indígena y sus consecuencias se explorará en la primera sección de este trabajo. Primero habrá que examinar las maneras en que aparece

\footnotetext{
${ }^{1}$ Vea el Apéndice A para el contenido completo de las entrevistas personales con Simanca Pushaina.
} 
esta práctica de infantilizar; en el caso de Siosi Pino y Simanca Pushaina, se la percibe no únicamente en las temáticas desarrolladas en sus textos, sino también en las posibilidades coartadas para el reconocimiento literario de los escritores indígenas y su potencial en el entorno de una literatura nacional. Se verá que estos cuentos, además de entretener y permitir entrar en el universo Wayuu, cuestionan ciertas representaciones o prácticas coloniales tales como la imagen del indígena como niño inocente, lo que logran realizar, en parte, al invertir las posiciones tradicionales de poder (entre el mundo-niño y el mundo-adulto, por ejemplo), rompiendo la jerarquía tradicional con la frecuente integración del "niño sabio". Simultáneamente, las obras de ambas escritoras cumplen una función didáctica que imparte conocimiento sobre la realidad indígena moderna tanto a las nuevas generaciones de los Wayuu como a la sociedad colombiana en general. Para resumir, uno de los propósitos principales del presente trabajo es demostrar y analizar la gran variedad de funciones (de criticar, denunciar, enseñar, apreciar, rememorar, entretener, proveer acceso a una cultura) y valor (literario, cultural, reconciliatorio) que los cuentos ofrecen a sus lectores. Además, este trabajo pretende revelar que su alto nivel de complejidad no concuerda con una clasificación en el género infantil ni juvenil.

A pesar de su relativa fama y conocimiento regional como figuras influyentes en el ámbito literario indígena, las dos autoras Wayuu han podido publicar muy poco. Aparte de su inclusión en unas antologías, las obras literarias de Siosi Pino y Simanca Pushaina sufren de una circulación muy restringida. ${ }^{2}$ Los cuentos de Siosi Pino que analizaremos en este trabajo, "No he vuelto a escuchar los pájaros del mundo", "Esa

\footnotetext{
${ }^{2}$ Se incluyen los cuentos de Estercilia Simanca Pushaina y Vicenta Siosi Pino en las antologías Pütchi Biyá Jai (2 volúmenes) y El sol babea jugo de piña, ambas editadas por Miguel Rocha Vivas y publicadas con el apoyo del Ministerio de Cultura de Colombia en 2010, y en la antología Wayuu Hermosos invisibles que nos protegen, compilada por Juan Duchesne Winter y publicada en 2015.
} 
horrible costumbre de alejarme de ti”, y "El dulce corazón de los piel cobriza”, forman parte de una colección de cuentos, la única de esta autora que se ha publicado hasta el momento. Esta colección, que salió en 2002 en formato de libro impreso, también titulada El dulce corazón de los piel cobriza, fue editada y apoyada por el Fondo Mixto para la Promoción de la Cultura y las Artes de la Guajira.

Simanca Pushaina ofrece su obra literaria casi completa a los lectores de su blog, pero aparte de esta fuente virtual son pocos los cuentos que se han publicado en casas editoriales oficiales. ${ }^{3}$ Los cuentos de Simanca Pushaina que más interesan en este trabajo son "El encierro de una pequeña doncella", cuento publicado por la casa cultural Comfamiliar del Atlántico en 2003 y "Manifiesta no saber firmar. Nacido: 31 de diciembre”, texto que apareció por primera vez en 2006 en una publicación auspiciada por la casa editorial Antillas de Barranquilla. Luego, en 2008, la autora lanzó una segunda edición diseñada y publicada por ella misma. ${ }^{4}$ Una de las limitaciones en el proceso de investigación para este trabajo ha sido conseguir los textos primarios en sí. Por supuesto, el hecho de que los ejemplares físicos (y no virtuales) de sus cuentos son tan escasos y difíciles de obtener (sobre todo, para los lectores fuera de Colombia) contribuye a restringir una circulación más internacional. Además, la falta de acceso impide el progreso de algunos de los principales objetivos de ambas autoras Wayuu tales como la valoración literaria de su obra escrita y la reivindicación de los derechos indígenas.

\footnotetext{
${ }^{3}$ Simanca Pushaina, abogada además de escritora, ha publicado muchos cuentos suyos, junto con noticias de interés indígena y Wayuu, en su blog personal (http://manifiestanosaberfirmar.blogspot.com). El énfasis en el blog de la autora, quien ha comentado la gran utilidad de este formato para alcanzar a sus seguidores más jóvenes, revela una estrategia de Simanca Pushaina para circunvalar los límites definidos por el restrictivo sistema literario y los normas sociales.

${ }^{4}$ Refiérase a la figura 5 (página 42) de esta tesis para ver la portada de la edición de la autora.
} 


\subsection{Breve contexto histórico}

La investigación y el reconocimiento de la literatura indígena colombiana es un fenómeno relativamente reciente. En Colombia, a diferencia de algunos otros países latinoamericanos con poblaciones indígenas más significativas como el Perú y México, las voces literarias de los grupos indígenas no fueron ampliamente reconocidas hasta las últimas décadas del siglo XX. ${ }^{5}$ Durante los años 90 se estrenó en Colombia una nueva literatura nacional, esta vez escrita por los propios indígenas y, en muchos casos, publicada en ediciones bilingües en reconocimiento de las más de 66 lenguas nativas que se habla actualmente en el país (Landaburu s.p.). Estos avances literarios de la última década del siglo XX coinciden con dos importantes momentos históricos en América Latina y para la nación colombiana: la nueva constitución de 1991, en la cual Colombia se define como un país multiétnico y pluricultural, así como el quinto centenario, en 1992, del año que marcó el inicio de la colonización de las Américas (Rocha, Textualidades 1). Ambos sucesos señalaron una encrucijada para los indígenas y conllevaron altas esperanzas de cambio social. Las conmemoraciones de 1992, inseparables de las tragedias de la Conquista y sus irreversibles consecuencias en la población indígena (injusticia, destrucción, exterminio, esclavitud), provocaron mucha

\footnotetext{
${ }^{5}$ Por ejemplo, en el Perú se apreciaron las literaturas indígenas mucho antes que en el caso colombiano. Se destaca la importancia del año 1938, fecha en la cual José María Arguedas publicó su colección de canciones quechuas (Canto kechwa), como un momento fundamental en el movimiento artístico de los indígenas andinos. También en 1938, el historiador Jorge Basadre editó un conjunto de textos de origen quechua titulado Literatura Inca. Estas dos contribuciones revelan "una naciente disposición a incorporar al corpus literario en castellano textos de origen quechua" (Cortez 103). En México, el indigenismo tiene un desarrollo temprano en México y continúa a través del siglo XX (Los más interesados pueden consultar las obras de Antonio M. Bolio, Eduardo Luquin, José Revueltas y Rosario Castellanos). Además, se considera la publicación de 1959 de Visión de los Vencidos de Miguel León-Portilla como un punto de inflexión para los indígenas de México. Este texto demuestra, por primera vez, la perspectiva del otro al centrarse en la percepción del indígena frente a una nueva realidad (a raíz de la Conquista) que "rompió con el orden propio de su universo" (Máynez 395).
} 
polémica por todo el continente americano.

El reconocimiento oficial del año 1492 inspiró reacciones de orgullo a la vez que produjo numerosas demonstraciones y reclamaciones críticas en contra de lo que algunos consideraban una glorificación de la Conquista. En general, los grupos indígenas de países latinoamericanos no vieron el quinto centenario de la llegada de los colonizadores a las Américas como motivo de celebración. Miguel Rocha Vivas describe la época histórica que rodea el quinto centenario como un "revolcón espacio-temporal... que a la vez podría ser entendido como el momento de retornar arriba lo que había quedado abajo tras la larga noche de los quinientos años" (Textualidades 6). El año 1992 se ha considerado un "nuevo amanecer” para los pueblos indígenas de toda América Latina, momento en el cual muchos indígenas por fin encontraron el espacio para poder vociferar sus denuncias del maltrato y protestar una larga historia de injusticias, tanto las que tuvieron que sufrir sus antepasados como las que ellos mismos siguen aguantando hasta el día actual. ${ }^{6}$

En Colombia, la nueva carta constitucional de 1991 promete reconocer y proteger la multiculturalidad del país y declara este objetivo una verdadera prioridad; a lo largo del documento constitucional se encuentran más de 30 referencias a los grupos indígenas o a la diversidad étnica y cultural. ${ }^{7}$ Es más, para revalidar la importancia de la pluralidad lingüística, también se ha traducido la Constitución de Colombia en siete lenguas indígenas, incluyendo el Wayuunaiki, lengua nativa de los Wayuu. Según Rocha Vivas,

\footnotetext{
${ }^{6}$ También en 1992, Juan Pablo II pidió perdón a los indígenas por los abusos de la Iglesia y Rigoberta Menchú, activista indígena guatemalteca, recibió el premio Nobel de la Paz por sus esfuerzos en la lucha por la justicia social y los derechos de los indígenas.

${ }^{7}$ Vea la página web de la Procuraduría General de la Nación para la carta constitucional completa: http://www.procuraduria.gov.co/guiamp/media/file/Macroproceso\%20Disciplinario/Constitucion_Politica_ de_Colombia.htm.
} 
la Constitución de 1991 ofreció a los indígenas unas nuevas esperanzas de una alternativa social y abrió el debate sobre la posibilidad de una nueva nación colombiana (Textualidades 6). Mientras que el periodo de los 90s hasta el día actual ha presentado una mayor visibilización de la producción literaria de los indígenas colombianos, hay que mencionar también las dos décadas de esfuerzo indígena que precedieron el surgimiento literario en las cuales se organizaron varios movimientos, emprendidos por una colaboración de diversos grupos nativos, para luchar hacia mejores condiciones y con el fin de reafirmar su identidad indígena. ${ }^{8}$

En cuanto a las dos escritoras Wayuu cuyas obras constituyen el enfoque principal de este trabajo, ambas iniciaron su carrera literaria dentro de este contexto de transición para las poblaciones indígenas, tanto en Colombia como en numerosos otros países latinoamericanos. ${ }^{9}$ La primera publicación de Siosi Pino salió en 1992 con la inclusión de su cuento "Esa horrible costumbre de alejarme de ti" en la célebre Woummainpa, un serie de cuadernillos Wayuu financiados por la Gobernación de la Guajira, así convirtiéndose en la primera escritora en ser publicada en esta revista (Rocha Vivas, Pütchi Biyá Uai I 101). La obra de Simanca Pushaina se hizo conocer por primera vez en 2002 con la publicación de un libro de poesía: Caminemos juntos por las sombras de la sabana (Rocha Vivas, Pütchi Biyá Uai II 87). A pesar de recibir bastantes elogios y reconocimiento con esta primera publicación, poco después la escritora demostró su preferencia por el formato del cuento corto, y en 2003 publica uno de sus más

\footnotetext{
${ }^{8}$ Las primeras organizaciones indígenas salieron en los años 70 y 80; en el departamento del Cauca, se estableció el Consejo Regional Indígena del Cauca (CRIC) en 1971 y la Organización Nacional Indígena de Colombia (ONIC) se formó en 1982.

${ }^{9}$ Vicenta María Siosi Pino nació en 1965 en San Antonio de Pancho, una ranchería en la media Guajira. Estercilia Simanca Pushaina nació en la ranchería El Paraíso, parte del resguardo indígena Caicemapa, ubicado en la baja Guajira (Rocha, Pütchi Biyá Jai I 101 y II 87).
} 
renombrados, "El encierro de una pequeña doncella". ${ }^{10}$

No obstante, también en los años 90 los conflictos armados oscurecieron la recién emergencia de nuevas voces indígenas en Colombia. Durante estos años de violencia muchos indígenas se encontraron en medio de una guerra que no reconocían como suya. De todos modos, muchos terminaron afectados directamente por la presión de las fuerzas guerrilleras o los paramilitares, victimizados cruelmente o desplazados de sus tierras nativas por una ocupación forzada. En La masacre de Bahía Portete: Mujeres Wayuu en la mira (2010), libro de memoria histórica que detalla la tragedia de 2004 perpetrada por el grupo paramilitar de las AUC, los autores explican que los actos de violencia contra los indígenas en general tienen un efecto multiplicador y catastrófico en sus comunidades; dichas violaciones de los derechos humanos básicos amenazan la propia supervivencia de estos grupos étnicos además de perjudicar su patrimonio cultural, histórico y mítico (1920). ${ }^{11}$ Rocha Vivas explica que el conflicto armado y el fortalecimiento de los grupos paramilitares “ensombrecieron las esperanzas y vientos de cambio de los principios de los noventa en Colombia" (Textualidades 9). Mientras los grupos indígenas en Colombia se convirtieron en víctimas de una violencia perpetrada tanto por el Estado como por los grupos armados de guerrillas y paramilitares, los escritores Wayuu y su llamada a una recuperación y revaloración cultural fueron relegados y subestimados con la aparición de nuevos problemas sociales más apremiantes en la nación colombiana.

\footnotetext{
${ }^{10}$ El primer y único poemario de Simanca Pushaina obtuvo el segundo puesto en el Tercer Concurso Nacional de Poesía convocado desde Barranquilla (Rocha, Pütchi Biyá Jai II 87).

${ }^{11}$ La masacre de Bahía Portete resultó en la muerte de 12 individuos Wayuu y causó que más de 400 indígenas fueran desplazados. Según el Grupo de Memoria Histórica, organización responsable para la publicación del libro arriba mencionado, "la masacre es un recurso criminal para doblegar la resistencia de la comunidad wayuu, en el marco del proyecto de consolidación del dominio militar y territorial del Bloque norte de las Autodefensas unidas de Colombia (AUC) en esta región del norte colombiano" (Masacre 19).
} 
Asimismo hay que aclarar que mientras que los 90s proveyeron el terreno fértil para el florecimiento de estas nuevas voces indígenas, esto no señala una falta de riqueza artística y cultural de las generaciones anteriores. Esta década no marca un surgimiento sino más bien una mejor visibilización de las culturas y literaturas indígenas que antes habían sido eclipsadas por la cultura dominante. Con referencia a las artes verbales Wayuu, Juan Duchesne Winter, compilador de la antología Wayuu más reciente, Hermosos que nos protegen (2015), explica que sólo se puede aplicar el término "literatura emergente" a estas obras indígenas si se reconoce que estas literaturas "surgen desde un acervo milenario de artes verbales y expresivas nativas parcialmente asordinado por la colonialidad anterior y posterior a las independencias nacionales" (9). Sin embargo, Duchesne Winter declara que, aunque esta tradición literaria siempre ha estado activo, ahora entra en una nueva fase expansiva que permite un reconocimiento más global (9).

Rocha Vivas corrobora la misma afirmación con sus investigaciones de las tradiciones oral-literarias de diversos grupos indígenas de Colombia. Describe en su libro Palabras mayores, palabras vivas que la gran mayoría de los primeros autores Wayuu que lograron ser publicados cumplieron en parte con el rol de hacer visibles, a través de la palabra escrita y el formato impreso del libro, las tradiciones míticas que son predominantemente orales (27). Se verá que muchos de estos rasgos de la oralidad tradicional Wayuu se presentan en la literatura escrita de Simanca Pushaina y Siosi Pino. Es más, el formato del cuento corto y la inclusión de ciertas técnicas narrativas hacen que los textos de ambas autoras contemporáneas adquieran una entonación y un carácter didáctico similares a las historias orales que se transmiten de generación en generación. 


\subsection{Contexto cultural: Los Wayuu}

En general, los grupos indígenas en Colombia viven primariamente en zonas dispersas en las regiones más remotas del país, resultando en un aislamiento general además de una separación geográfica y cultural. ${ }^{12}$ Los grupos indígenas en Colombia no constituyen un gran porcentaje de la población como es el caso de otros países

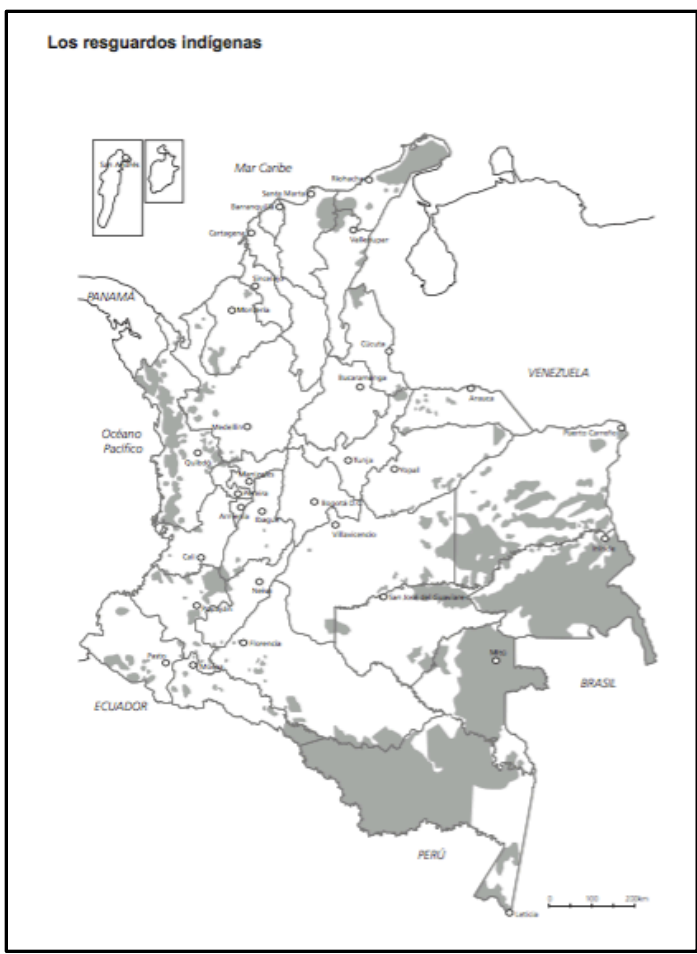

Figura 1: Mapa de resguardos indígenas en Colombia (Sánchez Gutiérrez y Molina Echeverri 28) latinoamericanos: Según las estadísticas del censo general de la organización DANE de 2005, solo 3,43\% de los colombianos, o 1.392.623 habitantes, se identifican como indígenas. Sin embargo, los resguardos indígenas (figura 1), los cuales en muchos casos corresponden a su territorio ancestral, ocupan un gran porcentaje de la tierra nacional. ${ }^{13}$ Es más, según lo que expone Joanne Rappaport en su libro Intercultural Utopias: Public Intellectuals, Cultural Experimentation, and Ethnic Pluralism in

Colombia, dentro de estos territorios se encuentra un $80 \%$ de los recursos minerales del país (1). Se verá más adelante en este trabajo que este hecho resulta en un constante

\footnotetext{
${ }^{12}$ A pesar de este aislamiento, los indígenas habitan todos los departamentos colombianos. Los de mayor porcentaje de población indígena son Vaupés (66,65\%), Guainía (64,90\%), La Guajira (44,94\%), Vichada $(44,35 \%)$ y Amazonas $(43,43 \%)$. A excepción de La Guajira estos departamentos hacen parte de la Orinoquia y la Amazonia (Romero 29). Cabe notar que los Wayuu de La Guajira suelen tener más contacto con otros grupos (colombianos e internacionales) por su posición geográfica.

${ }^{13}$ Según el censo de 2005 había 710 resguardos titulados, los cuales ocupaban una extensión de aproximadamente 34 millones de hectáreas, el 29,8\% del territorio nacional (Romero 31).
} 
conflicto entre los Wayuu, en particular, y las compañías transnacionales que buscan explotar sus recursos como el gas natural, el carbón y la sal.

Los Wayuu constituyen el segundo grupo indígena más grande de Colombia; su territorio incluye el departamento de la Guajira en el norte de Colombia, donde la población indígena comprende el 44,94\% de la población total (Romero 29) y el estado de Zulia al noroccidente de Venezuela. Los Wayuu típicamente se mueven libremente entre los dos países, reconociendo la frontera como una invención de los alijuna, o los no Wayuu, pero a la vez son sometidos a su imposición bifurcando el espacio Wayuu (Giraldo 53).${ }^{14}$ Dado esta división de territorio entre dos naciones modernas, valdría la pena considerar en futuros investigaciones cómo los Wayuu forman parte o contribuyen a la idea de la nación o a las percepciones de la colombianidad. ${ }^{15}$ Frecuentemente el proceso de incorporarlos a los Wayuu en los sistemas oficiales colombianos lleva a conflictos y abusos. Utilizando el término de Mary Louise Pratt, este espacio físico y social de la Guajira puede considerarse una "zona de contacto". Según lo define en su artículo, "Arts of the Contact Zone", esta expresión refiere a los espacios sociales en donde las culturas se encuentran, se colisionan y se lidian, a menudo en contextos de relaciones altamente asimétricas de poder, tales como el colonialismo, la esclavitud, o en

\footnotetext{
${ }^{14}$ Alijuna, el término que se aplica a todos los individuos no Wayuu, a veces aparece escrito como arjiuna, ya que la ele en Wayuunaiki se pronuncia como la ere en castellano. Francisco Justo Pérez van-Leenden, en "Wayuunaiki: Lengua, sociedad, y contacto", distingue entre diversos usos de este término: "[...] debida a la intensidad del contacto, actualmente existen los alijuna kachako, alijuna krinko, alijuna turko; son referentes de la población del interior de Colombia, de Estados Unidos y Europa y del Oriente, respectivamente, que de manera ocasional o permanente ocupan el territorio peninsular" (195).

15 "La colombianidad" es un concepto difícil de definir ya que las interpretaciones de lo que significa ser colombiano son tan diversas. En su artículo "Qué es la colombianidad" de la revista La Semana, Oscar Collazos determina que "equívocamente se trata de definir qué es ser colombiano, destacando defectos y virtudes. Pero ni siquiera las estadísticas pueden dar una respuesta. Por eso la esencia del colombiano es su complejidad". Se puede agregar a esta declaración que desde la perspectiva indígena se multiplica de manera exponencial esta complejidad.
} 
contextos de sus secuelas, como se experimentan en muchas partes del mundo hoy en día (34). Dicho enfrentamiento se observará explícitamente en el cuento de Simanca Pushaina, "Manifiesta no saber firmar. Nacido: 31 de diciembre", que revela las injurias en contra los Wayuu durante los esfuerzos afanosos a cedularlos; todo con el fin de que puedan votar en cualquier elección sea la más inminente.

La región de la península de la Guajira, que hoy en día se considera una "zona de contacto" cultural entre el grupo indígena Wayuu y otras colectividades, sean el Estado colombiano subyugante o las empresas multinacionales gigantescas que la minan, también es territorio ancestral Wayuu. Mucho antes de ser conocida por el legendario Cabo de la Vela, uno de los primeros puntos de referencia en la tierra de las "Indias" en las expediciones de Alonso de Ojeda, los Wayuu lo llamaron Jepira, o "senda por donde las almas de los Wayuu muertos recorren el camino hacia su última morada, en el fondo del mar" (Cardozo y Correa 1.1 s.p.). Es una región árida que sufre de grandes deficiencias de agua durante los largos periodos de sequía, típicamente duran 9 o hasta 10 meses del año; la disputa sobre los derechos al agua y el acceso a este recurso esencial siguen siendo debates de importancia primordial hoy en día. ${ }^{16}$

Cuando llegaron los españoles en 1499, los Wayuu (previamente conocidos como los guajiros) eran una tribu de cazadores y pescadores que además subsistían de la horticultura. Sin embargo, poco después empezaron a adquirir ganado de los españoles recién llegados y para finales del siglo XIX, la mayoría de los Wayuu ya se habían convertido en pastores mientras que la subsistencia basada en la caza había disminuido

\footnotetext{
${ }^{16}$ Refiérase al Apéndice B donde se reproduce la carta escrita por Vicenta Siosi Pino al presidente Juan Manuel Santos, solicitando su ayuda en detener los proyectos de la compañía Cerrejón de desviar el río Ranchería (fuente esencial de agua para la zona de la Guajira) para beneficiar la industria minera. También se puede consultar la nota 16 de la página 13 para más detalles sobre el asunto.
} 
significativamente en importancia (Perrin, Folk Literature 2). Hoy en día el Wayuu sigue siendo un pueblo de pastores y pescadores-las mujeres en muchos casos se dedican a trabajos domésticos o al tejido de las apreciadas mochilas Wayuu-pero la atracción hacia los grandes centros urbanos es todavía fuerte, tanto por el lucro como por la necesidad. En muchos casos los hombres o jóvenes viajan a las ciudades o viven lejos de su ranchería para poder trabajar en la minería de sal o carbón.

Según Cardozo y Correa, los grupos de Wayuu que habitan la península actualmente son "cada vez más deculturados y subordinados al orden agropecuario y a las industrias de extracción del área"(1.2 s.p.). ${ }^{17}$ Michel Perrin, etnólogo y antropólogo francés que vivía entre los Wayuu para estudiar sobre todo su mitología y literatura folklórica, ofrece una crítica más aguda. En la introducción de su libro The Way of the Dead Indians: Guajiro Myths and Symbols (1976), Perrin explica que los Wayuu de aquel momento viven cada vez más en contacto cercano con lo que típicamente se denomina la "civilización” (xi). Esta supuesta civilización se presenta en su máxima supremacía en Maracaibo (Venezuela), centro de la industria petrolera del país que “atrajo a un gran número de hombres guajiros, los agotó en trabajos temporales e ingratas, luego los rechazó o los destruyó, y que ahora continúa inexorablemente a mermar la sangre vital de todo un pueblo" (Perrin, Dead Indians xi).$^{18}$ Conforme con lo que describe Perrin, uno de los primeros académicos en publicar acerca de la cultura

\footnotetext{
${ }^{17}$ Entre las industrias con más influencia en la zona hay que mencionar la mina de tajo abierto El Cerrejón, cuarta en su género en el mundo, con capacidad de producción anual de 15.000.000 de toneladas (Cardozo y Correa 1.2 s.p.). La propuesta de El Cerrejón de desviar el río Ranchería inspiró la denuncia pública de Vicenta Siosi Pino, cuya carta al presidente Juan Manuel Santos veremos más adelante en este trabajo (Para el texto completo de esta carta, vea el apéndice B). En 2012, la compañía decidió posponer el proyecto ("Cerrejón pospone estudios sobre la posible desviación del río Ranchería").

${ }^{18}$ Traducción mía.
} 
Wayuu, la intersección de la comunidad indígena con la supuesta "civilización" de la cultura dominante ha resultado en un círculo vicioso de engaño, esclavitud, y pobreza.

En la traducción citada arriba, Perrin refiere a la "sangre vital" de los Wayuu: el alma, la fuerza, o la energía vital de toda una población. Según el contexto, se supone que para este antropólogo, la energía vital Wayuu viene de los hombres. No obstante, como se intentará exponer en este trabajo a través de un análisis literario, el alma de los Wayuu siempre ha sido femenina. A pesar de las limitaciones impuestas en ellas, no solamente por la sociedad tradicional Wayuu, sino también por las prácticas patriarcales que cada mujer se enfrenta, las mujeres Wayuu siguen siendo la energía vital de la comunidad. De acuerdo con lo que expresa Duchesne Winter en su antología, "el destino de los pueblos indígenas está íntimamente ligado al destino de la mujer indígena” (35); las mujeres Wayuu no son únicamente las principales encargadas con la supervivencia de la comunidad por medio de sus capacidades reproductivas, sino también representan una fuente importante de sus historias, tradiciones y mitos. Es más, la nueva fuerza femenina, puesta en evidencia por la escritura innovadora y denunciatoria de Simanca Pushaina y Siosi Pino, revela las oportunidades actuales para un cambio literario y social tanto para los Wayuu como para otras diversas poblaciones indígenas.

En las comunidades Wayuu, los hijos mantienen el apellido y herencia de la madre, ya que los hombres tienen el derecho a tantas mujeres como se lo permite la condición económica y la posición social. En una entrevista, Vicenta Siosi Pino describe a su propio padre de tal manera: "Era un hombre honesto, muy correcto. Mujeriego, como buen wayuu. Él es primo de mi mamá, pero tuvo muchas mujeres. Imagínese, yo tengo 21 hermanos" (De la Hoz Simanca s.p.). Como es todavía común la práctica de la 
poligamia, el sistema matrilineal es el que determina la descendencia, herencia, propiedad y residencia de los Wayuu. Los papeles de los géneros son bastante tradicionales en muchos casos y las mujeres típicamente se ocupan de las tareas domésticas mientras que los hombres, en muchos casos, son menos estables y suelen moverse por donde aparezcan las oportunidades laborales.

Explican Cardoza y Correa que la mujer Wayuu, gracias a esta condición central en la filiación, se ha establecido firmemente en la estructura cultural wayuu: "Su prestigio, y con él su manejo de la memoria del grupo y de la tradición, aún se mantiene a partir de su función social básica: aumentar su propio grupo" (2.6.1 s.p.). Como describe José Ramón Lanao Loaiza en su memoria guajira de 1936, Las pampas escandalosas, la mujer indígena sabe bien que el matrimonio y la maternidad no son más que formas de trabajar sin salario: "La india, acostumbrada a trabajar y resignada a la esclavitud de un hogar que ha formado más de las veces sin su voluntad amorosa, porque ha sido cedida al mejor postor, lleva en su sonrisa la claridad crepuscular de una melancolía despechada" (27-28). Ochenta años después, esta situación sigue siendo el destino inevitable de muchas mujeres Wayuu. Reflexionando sobre los distintos papeles de género entre los hombres y las mujeres en la sociedad, Simanca Pushaina, abogada y empresaria de moda étnica además de escritora renombrada, ofreció la siguiente comentario: "[Mi experiencia] es privilegiada por mi entorno, mi realidad con respecto a la de muchas mujeres Wayuu de mi edad que no pudieron estudiar o simplemente no quisieron. Hay mujeres Wayuu de 40 años que ya tienen nietos y han parido 10 veces. Derivan su sustento de la artesanía u otras actividades" (entrevista personal). A través de los cuentos de Simanca Pushaina y su coterránea Siosi Pino, se puede percibir directamente esta 
desigualdad. En las diversas representaciones de mujeres Wayuu en sus obras, aparecen imágenes de la mujer fuerte, emprendedora y exitosa ("El encierro de una pequeña doncella", de Simanca Pushaina, por ejemplo). Al mismo tiempo, se presenta otra realidad, una de pobreza extrema y desespero, lo que representa una existencia realista para muchas Wayuu actualmente ("No he vuelto a escuchar los pájaros del mundo" o "Esa horrible costumbre de alejarme de ti", ambos ejemplos de Siosi Pino).

Por otro lado, se lee en el documento de política etno-educativa Anaa Akua'ipa, publicación llevada a cabo por unos educadores Wayuu y auspiciada por el Ministerio de Educación Nacional, que "la cultura Wayuu tiene predeterminados los roles por género y por actividades socioeconómicas y socioculturales; sin embargo, la libertad de elegir lo que se quiere hacer se ejerce ante las posibilidades de elección frente a diversas situaciones” (29). Según se expone en el documento, cada mujer Wayuu tiene la opción de elegir entre las varias posibilidades que se les presenten (en cuanto a la educación o al trabajo, por ejemplo). En otras palabras, es la opinión de los educadores indígenas que las mujeres Wayuu modernas, a pesar de tener los roles de género "predeterminados", sí pueden disfrutar del libre albedrío. No obstante, es igualmente posible interpretar esta afirmación más bien como un deseo para el futuro, y no tanto como un reflejo de la realidad actual. El proyecto Anaa Akua'ipa tiene como objetivo institucionalizar la educación a la manera Wayuu y, como discierne Simanca Pushaina, es una gran esperanza para la etno-educación bilingüe (Duchesne Winter 463). En los cuentos de Siosi Pino y Simanca Pushaina, por ejemplo, se revelan otras realidades femeninas que ponen en cuestión esta declaración de los educadores/el Ministerio de Educación sobre la verdadera autonomía de la mujer Wayuu. Sin duda, habrá que investigar más al fondo 
para entender cuál de estas dos realidades-posiblemente ambas o alguna combinación-es la que realmente representa la mayoría de las mujeres Wayuu en la actualidad.

Las mujeres Wayuu tradicionalmente pasan por un encierro, tema central del cuento "El encierro de una pequeña doncella" por Simanca Pushaina, en lo cual quedan encerradas al iniciar su primera menstruación. El encierro puede durar unos días (en la modernidad, si se sigue observando el rito) hasta unos años (tradicionalmente), y no se les permite ningún contacto con el mundo exterior. El rito marca la transición de la niñez a la madurez y, como explica Watson-Franke en su artículo "Seclusion Huts and Social Balance in Guajiro Society”, es un proceso arduo pero honorable para las jóvenes:

[The young female] has to undergo a period of fasting and must take medicines, one of them being a contraceptive. She receives cold baths believed to give her beautiful skin and to strengthen her personality. Her hair is cut short and this hair is hidden in a secret spot to insure her future success as a woman [...]. Any contact with the outside world is considered to be harmful to her. The secluded girl is described as special, vulnerable and as sacred. At the end of the seclusion she is considered to be a responsible adult woman prepared to take on responsibilities as a member of the matrilineage and as a wife. (452-3)

En el tercer capítulo del presente trabajo se explorará esta práctica ancestral del encierro a través del cuento de Simanca Pushaina. Con su historia, la autora nos invita al espacio prohibido-al interior del rancho de una joven encerrada-y hasta más adentro al permitirnos compartir con el personaje principal todos las sensaciones, sean alegrías o agonías, mientras ella experimenta los tres años de su encierro. El relato incluye numerosas referencias a los mismos elementos comentados arriba por Watson-Franke, tales como el rapar de su cabello, la purificación mediante los brebajes y los baños en agua fría, y, sobre todo, la reverencia sagrada hacia la joven encerrada. Como el título del 
cuento sugiere, es común en el rito tradicional referirse a la joven encerrada como una doncella o una princesa.

Una de las expectativas al salir del encierro es que la niña ya se haya convertido oficialmente en mujer y que esté preparada para la próxima etapa en el ciclo de vida Wayuu. Cardoza y Correa explican que la salida de la joven generalmente es ocasión de una fiesta familiar, "especie de presentación en sociedad entre los suyos de una nueva mujer apta para el matrimonio" (2.6.1 s.p.). Típicamente la madre y/o el tío materno son los responsables en manejar el proceso de emparejarla con un esposo adecuado y controlan la negociación de su valor. Al contratar un matrimonio, todavía es costumbre pagar una dote, lo que típicamente se define por cierta cantidad de ganado o propiedad. Comentando sobre esta práctica tradicional Wayuu, todavía corriente hoy en día, Simanca Pushaina declara que "en el pasado quizás estuvo bien porque la dote tiene su razón de ser. Pero lo que yo veo en algunas familias Wayuu es la venta pura y simple de la niña, no una dote como tal" (entrevista personal). Los niños en las comunidades Wayuu no pasan por ningún rito de iniciación pero, como han señalado Correa y Cardoza, el acceso a ciertos instrumentos de trabajo o a las armas denotan unas transiciones en el ciclo de vida de los hombres: "el tránsito de la cauchera y aún en ciertas zonas del arco y las flechas a las armas de fuego, por ejemplo, dentro de las cuales también hay su gradación, según su modernidad” (2.6.1 s.p.). Los niños Wayuu también trabajan, sean en el pastoreo o la pesca, y estas necesidades laborales suelen dificultar la realización de una educación básica.

En las familias Wayuu todos los miembros tienen su papel claramente definido y, debido a las condiciones extremas de pobreza, todos hasta los niños participan en el 
sustento de la comunidad. La

sociedad Wayuu es organizada en

clanes matrilineales, los cuales

tradicionalmente son asociados

con un animal totémico. Perrin

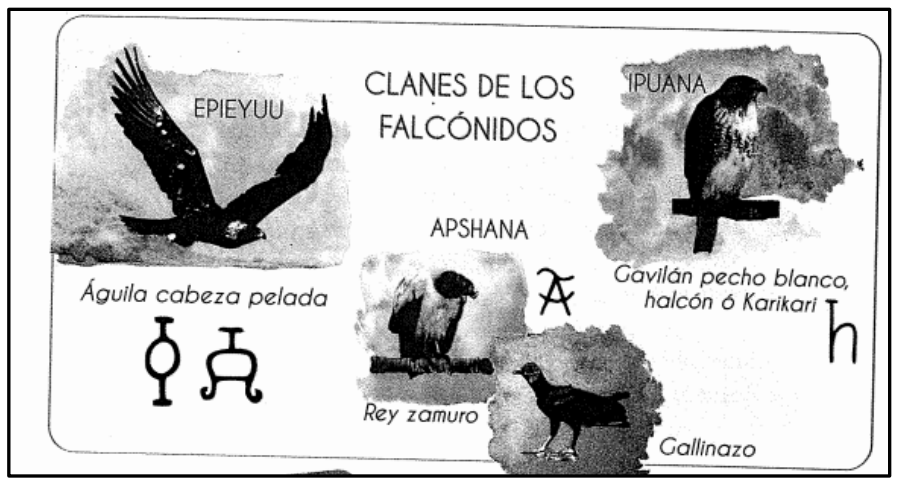

señala que, en teoría, la identidad

social de un individuo y su estatus

Figura 2: Nombres de unos clanes Wayuu con su animal totémico y el símbolo asociado (Vizcaíno Escobar 32)

se definen por su asociación con cierto clan. Describe en la introducción de su libro que

algunos clanes cargan la reputación de ser los más pobres-por ejemplo, el clan Wouliyu, asociado con el perdiz-mientras que otros tienen el fama de ser más ricos y

potencialmente poderosos como los Uliana, el clan asociado con el jaguar (Dead Indians xiv). En el caso de las dos autoras, se asocia el clan Pushaina con el zaíno-cerdo y el clan Apshana (herencia de Vicenta Siosi Pino) con el rey zamuro (Vizcaíno Escobar 32-34).

No obstante, Perrin aclara que la jerarquía social de los clanes ha perdido su importancia sociológica y política, pero el apellido del clan e inclusive su símbolo distintivo (figura 2) siguen siendo marcas identificadoras entre los Wayuu.

Los Wayuu residen en vecindarios, o sistemas de rancherías, poblados por familias extensas que típicamente comparten el derecho de acceso a una fuente de agua local. ${ }^{19}$ Actualmente los clanes no están localizados; como explica Vergara, "Los miembros de un clan... comparten el mismo apellido, pero la mayoría de las veces estas personas que comparten un mismo apellido no son parientes entre sí y están asociados a

\footnotetext{
19 "El territorio de un clan se determina por la existencia del cementerio familiar por línea materna; por eso muchos Wayuu expresan que el cementerio es la escritura de propiedad, testimoniada en la tumba de los antepasados, de quienes no debemos alejarnos y mantenemos contacto con ellos a través de los sueños" (Anaa Akua'ipa 21).
} 
territorios diferentes" (citado en Cardozo y Correa 2.0 s.p.). Cardoza y Correa describen que "estos sistemas de parentesco y patrones de residencia vertebran el sistema de conformación de las relaciones sociales Wayuu, que carecen de centralismo político y estructuran sus formas de representación de manera local, a partir de la serie de parientes uterinos" (2.0 s.p.). Esta falta de centralismo como comunidad indígena puede conducir a conflictos entre o dentro de los clanes lo que en muchos casos requieren la intervención de un intermediario para arreglar la disputa.

Para estas querellas, conflictos y crímenes entre los clanes, los Wayuu no suelen recurrir al sistema judicial colombiano, aunque el Estado sí intercede en algunos casos. En las comunidades Wayuu se mantiene un sistema normativo basado en el poder de la palabra. ${ }^{20}$ Inspirado en principios de reparación y compensación, las autoridades morales de la comunidad, los pütchipü' ’üi, o palabreros, aplican su don de la palabra para solucionar conflictos y ofensas de todo tipo. En La disputa y la palabra: La ley en la sociedad Wayuu, el antropólogo Weildler Guerra Curvelo explica que el sistema normativo de los Wayuu logra "dirimir sus querellas mediante variados mecanismos de control social que, en muchos casos, contemplan el uso de discursos persuasivos concretados en una retórica eficaz para el mantenimiento de la armonía social sin recurrir al uso de la fuerza y a cuerpos coercitivos como tribunales o policías" (29). Cuando surge un pleito, el pütchipü’üi interviene para examinar la situación y buscar una solución a través de medios pacíficos. En muchos casos el pütchipü'üi dialoga primero con los ofensores y los ofendidos de una forma separada para luego entablar una conversación reconciliatoria entre ambos grupos.

\footnotetext{
${ }^{20}$ Este sistema normativo, aplicado por el pütchipü'üi, fue inscrito en 2010 sobre la lista representativa del patrimonio cultural inmaterial de la humanidad de la UNESCO. (www.unesco.org)
} 
En una cultura que tanto valora el poder de la palabra, sin embargo, existe una limitación para las mujeres indígenas que ven sus posibilidades con la palabra truncadas: según la tradición Wayuu, ellas no pueden ser pütchipü’ üi. No obstante, la palabra tiene su poder pernicioso en el imaginario de los Wayuu; Perrin explica en su libro que algunos Wayuu, reconociendo con mayor facilidad que otros el poder de la palabra hablada, incluso evitan relatar ciertos cuentos por el temor de que éstos les traigan malos sueños o que les caiga la desgracia sobre ellos mismos (Dead Indians 75). Considerando esta máxima reverencia hacia la palabra en la cultura Wayuu, se puede entender los esfuerzos literarios de las escritoras Wayuu, Simanca Pushaina y Siosi Pino, como una forma de honrar esta creencia ancestral. Además, el acto de escribir puede ser su forma de participar en la tradición de los palabreros, a pesar de no ejercer la profesión pütchipü’üi en sí. La literatura, por lo tanto, se establece como un vehículo para transmitir y valorar el poder de la palabra, tanto para sus hermanos Wayuu como para los lectores alijuna.

\subsection{Contexto literario: La expresión Wayuu y su alcance}

Existen muy pocos estudios sobre la tradición literaria en la sociedad Wayuu debido a una producción limitada de literatura y una distribución restringida de las obras que logran publicarse. Para desarrollar este trabajo, una de las limitaciones más impactantes ha sido adquirir los textos primarios, un hecho significativo en la consideración de las posibilidades de influencia regional, nacional e internacional de las obras contemporáneas de Estercilia Simanca Pushaina y Vicenta Siosi Pino. La publicación de algunas antologías ha facilitado el acceso a la literatura Wayuu ya que muchos cuentos o poemas no se han podido publicar de una forma independiente o, si se publican, no benefician de una distribución muy extensa. En 1986, Michel Perrin, junto 
con Johannes Wilbert y Karin Simoneau, editó y publicó una colección de 233 textos en dos volúmenes, titulado Folk Literature of the Guajiro Indians, en que compila toda la literatura oral de los Wayuu que se había podido descubrir hasta aquel momento. En la introducción a estos volúmenes, Perrin traza una evolución o adaptación de los mitos orales del grupo indígena a lo largo de la historia conocida. Por ejemplo, nota que mediante la adopción de los animales de ganado, la sociedad Wayuu se ha transformado radicalmente; estos cambios fundamentales han afectado sus mitos, resultando en la adaptación, mutación o destrucción de su mitología tradicional (Folk Literature 2). Perrin desarrolla aquí una teoría que pone en evidencia tanto la originalidad mitológica de la sociedad Wayuu como su adaptabilidad a las necesidades sociales, culturales y económicas de cada generación.

Más recientemente, Víctor Bravo Mendoza ha contribuido a una mayor visibilización de los escritores Wayuu con varias colecciones de literatura Wayuu, incluyendo Cuentos de autores guajiros 2 (1995), La Guajira en su literatura (1997), y Cuentos (2007). En el prólogo de su primera colección, titulado "Palabras para un (des)cuento", Mendoza comenta sobre la falta de interés literario en la región: "Quienes ejercemos el oficio de la palabra escrita en el Departamento de la Guajira, debemos escatimar el vacío literario que nuestro medio se agiganta como desierto de letras" (5). Aquí Mendoza pide a sus compañeros literatos que le acompañen en sus esfuerzos de reunificar, a través de la literatura, los dispersas pueblos Wayuu. A la vez, parece que Mendoza también refiere al analfabetismo que padece la comunidad Wayuu en la 
Guajira, el "desierto de letras". ${ }^{21}$ En el cuento "Manifiesta no saber firmar. Nacido: 31 de diciembre", Simanca Pushaina comenta este nivel de alfabetismo entre las distintas generaciones Wayuu. Al mismo tiempo, hay que considerar las múltiples interpretaciones posibles de lo que significa ser "educado" o hasta "alfabetizado", tema que se investigará más en el capítulo 3.2 de este trabajo. ${ }^{22}$

La autora-abogada Simanca Pushaina confirma esta falta de producción literaria entre la comunidad Wayuu: "pese a que por medio de nuestros texto[s] saben de nosotros, [la literatura] no reviste mayor importancia en la población [Wayuu]. Hay asuntos por resolver antes de sentarse a escribir o leer" (entrevista personal). Sin embargo, parece que para esta autora y abogada la literatura sí tiene una función social importante que va más allá del arte como expresión personal o para el entretenimiento de los lectores. Como se explorará más adelante en esta investigación, los cuentos de Simanca Pushaina y de su coetánea Siosi Pino ofrecen muchos más niveles de interpretación de lo que se esperan típicamente dentro del género de literatura infantil. Las dos escriben para mejorar la situación de los Wayuu, bien conscientes de que la mayoría de los Wayuu están luchando por sobrevivir; por ahora, la escritura y la lectura no se encuentran entre sus necesidades más urgentes.

\footnotetext{
${ }^{21}$ Según el informe publicado por DANE en 2005, el nivel de alfabetismo (entre los individuos de 15 años y más) en las comunidades indígenas en Colombia es $71,4 \%$, una cifra más baja en comparación con el promedio nacional de 91,6\%). Sin embargo, el informe también identifica un descuido fundamental: $s$ necesario aclarar que la pregunta del censo para determinar el alfabetismo no especificó si se trataba del alfabetismo en castellano o en la lengua de su grupo, por lo que debe ser un factor a tenerse en cuenta en la formulación de las preguntas del próximo censo" (Romero 40-41).

${ }^{22}$ Refiérase al capítulo 6 de la tesis doctoral de Miguel Rocha Vivas para una investigación más detallada de los distintos conceptos del (an)alfabetismo y su aplicación a los grupos indígenas en Colombia (Textualidades 214-283).
} 
Gracias a las considerables contribuciones en la última década por Rocha Vivas, muchos más lectores han podido disfrutar de las obras literarias de estos escritores indígenas. En 2010, publicó la primera edición de su libro Palabras mayores, palabras vivas: Tradiciones mítico-literarias y escritores indígenas en Colombia, un texto que propone dialogar con el mundo indígena en Colombia y ofrecerles a sus escritores una mayor visibilidad. También en 2010, Rocha compiló varias antologías de literatura indígena colombiana: Antes el amanecer: Antología de las literaturas indígenas de los Andes y la Sierra Nevada de Santa Marta; El sol babea jugo de piña: Antología de las literaturas indígenas del Atlántico, el Pacífico y la Serranía del Perijá; y dos volúmenes de una antología

Este es un «Libro al viento». Es para que usted lo lea y para que lo lean muchos como usted. Por eso, cuando termine, devuélvalo y tome otro.

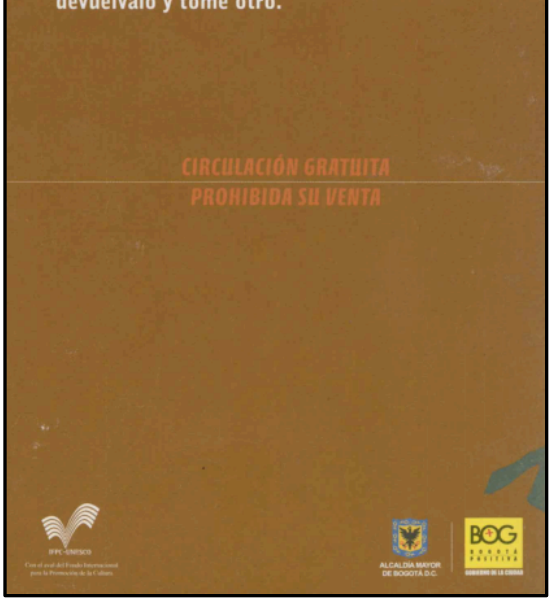

Figura 3: Contraportada de la antología Pütchi Biyá Uai II, un "libro al viento" patrocinada en parte por la alcaldía mayor de Bogotá, Pütchi Biyá Uai (2010). Esta última antología forma parte de una campaña de fomento de la lectura llamado "Libro al viento”. En la contraportada (figura 3) de ambos volúmenes de esta antología se lee el siguiente mensaje a los lectores: "Este es un 'libro al viento'. Es para que usted lo lea y para que lo lean muchos como usted. Por eso, cuando termine, devuélvalo y tome otro" (Pütchi Biyá Uai I, II s.p). Esfuerzos de este tipo ayudan, por lo menos en zonas urbanas como Bogotá, a promover las obras de escritores indígenas y facilitan su distribución al hacerlas disponibles de una forma gratuita. 
De igual forma, las bibliotecas virtuales como la Biblioteca Luis Ángel Arango proporcionan posibilidades para una mayor expansión de conocimiento a través de sus publicaciones de textos completos en línea; ambas antologías antes mencionadas, Antes del amanecer y El sol babea jugo de piña, son disponibles en formato descargable de PDF en la página web del Banco de la República bajo la sección de “Actividad cultural”. De todas formas, la distribución o reconocimiento de estas obras suele ser limitada a las grandes ciudades; por ende, hay que suponer que los indígenas, aunque producen su propia literatura, no cuentan con su propia comunidad entre sus lectores más ávidos. La antología más recientemente publicada, Hermosos invisibles que nos protegen (2015), compilado por Duchesne Winter, contiene no solamente textos de muchos escritores Wayuu anteriormente no publicados, sino también ofrece entrevistas con varios autores, entre ellos Simanca Pushaina y Siosi Pino. ${ }^{23}$

En su gran mayoría, la escasa tradición literaria de los Wayuu ha sido dominada por voces masculinas; entre los más notables cabe destacar a Ramón Paz Ipuana, Miguel Ángel Jusayú (del lado venezolano de la nación Wayuu), y Miguelángel López (también conocido como Vito Apüshana-Malohe). El surgimiento reciente de nuevas obras escritas por mujeres indígenas Wayuu como Simanca Pushaina y Siosi Pino ofrece al mundo de los lectores una alternativa al canon literario y abre el camino hacia nuevos tipos de conocimiento. Aunque el enfoque de este trabajo no es analizar la literatura Wayuu a través de una lente de crítica literaria feminista, es imprescindible explorar al menos unos aspectos básicos de las circunstancias específicas que influyen en la producción cultural

\footnotetext{
${ }^{23}$ Además, esta antología incluye unos escritos de Simanca Pushaina que antes no habían sido publicados aparte de la inclusión en el blog de la autora. Estos textos nuevos incluyen un ensayo de 2013 "Pulowi de Uuchimüin" (319-321) y un fragmento de una novela inédita Soy venado (323-329).
} 
de las escritoras en América Latina, sobre todo con respecto a las mujeres indígenas. Como determina Stacey Schlau en su introducción al libro Spanish American Women’s Use of the Word, "Without a clear recognition of the role that gender plays in women writers' lives and works, any literary analysis must remain not only fruitless, but dangerously partial" (xxiii). Sin lugar a dudas, la perspectiva femenina ofrece nuevas posibilidades de entender el mundo; poder apreciar la voz (escrita) de una mujer subalterna o marginada es doblemente valiosa. Schlau reconoce esta situación única de las autoras latinoamericanas, quienes han tenido que luchar no solamente contra la heteronomía política sino también contra el patriarcado (xv). Como se ha establecido previamente, los roles de género en la sociedad Wayuu son bastante rígidos y basados en una tradición claramente patriarcal. La palabra, cuando un hombre Wayuu la posee y sabe aplicarla, viene cargada de un poder impresionante-tanto que se la utiliza como la base de su sistema de justicia. Sin embargo, la mujer Wayuu no nace en condiciones que fomentan el empleo de la palabra de la misma manera. Por esta razón, el uso singular de la palabra por la parte de Simanca Pushaina y Siosi Pino representa no solamente una innovación sino también es un mecanismo de resistencia.

\subsection{Acercamiento teórico}

La base teórica que se implementará en este análisis tiene como propósito mejor orientarse acerca de ciertos conceptos. Además, se utilizará las ideas teóricas para apoyar la hipótesis sobre las obras de dos escritoras Wayuu y su inclusión - tanto la literatura como los propios indígenas - en una sociedad y cultura distintas a la suya. Para una teoría sobre la literatura indígena en general, se indagará una selección de textos del crítico peruano Antonio Cornejo Polar, sobre todo Escribir en el aire (1994), su ensayo sobre la 
heterogeneidad socio-cultural en la literatura andina. Estos conceptos son útiles al examinar el caso de las obras literarias de Vicenta Siosi Pino y Estercilia Simanca Pushaina en que los textos del crítico andino exploran "la índole excepcionalmente compleja de una literatura [indígena] (entendida en su sentido más amplio) que funciona en los bordes de sistemas culturales disonantes, a veces incompatibles entre sî́" (Cornejo Polar 17). Esta teoría ayuda a conceptualizar la inclusión de la literatura Wayuu en el sistema literario dominado por voces de la cultura hegemónica en Colombia.

Para las investigaciones acerca del género de literatura infantil, en particular en cuanto a las consecuencias implicadas en los cuentos estudiados por una categorización como tal, es apropiado el concepto de "paratexto", un término desarrollado por Gérard Genette en sus escritos teóricos en Paratexts: Thresholds of Interpretation (1997). Genette define el paratexto de una obra literaria como las producciones acompañantes, tales como el nombre de un autor, un título, un prefacio, ilustraciones, que no se sabe si hay que considerarlas como pertenecientes al texto o no: "In any case [these productions] surround it and extend it, precisely in order to present it, in the usual sense of this verb but also in the strongest sense: to make present, to ensure the text's presence in the world, its 'reception' and consumption” (1). Con esta declaración, Genette propone que el paratexto de un libro no solamente lo envuelve literalmente, sino también participa en la creación de dicha obra y hace posible su propia existencia como obra literaria. El paratexto influye en y complementa el significado "final" de cualquier obra, manipulando con diversas estrategias su recepción. La teoría de Genette ayuda a conceptualizar la influencia que ejercen ciertas producciones fuera del texto sobre la recepción e interpretación del mismo. En el caso de los cuentos de Siosi Pino y Simanca Pushaina, es 
especialmente impactante el paratexto en cuanto a las ilustraciones, el diseño de la portada, y los prólogos que, en la mayoría de los casos, no son escritos por ellas sino por otras entidades, sean los editoriales u otros compañeros académicos.

De otra parte, el trabajo de Gilles Deleuze y Félix Guattari sobre la literatura menor permitirá ampliar y repensar la interpretación de los cuentos de Simanca Pushaina y Siosi Pino notando que son, en muchos casos, obras politizadas con elementos de fuerte denuncia y crítica que han sido relegadas a una posición "inferior" de la literatura infantil. Según definen Deleuze y Guattari, “A minor literature doesn’t come from a minor language; it is rather that which a minority constructs within a major language [in which] everything is political ... [and] in it everything takes on a collective value" (166167). La definición de la literatura menor que desarrollan en su ensayo revela que tiene tres componentes o características: la literatura menor (a) debería desterritorializar el lenguaje mayor; (b) es una narrativa en la cual todo se vuelve político; (c) siempre es colectivo. En cuanto al lenguaje, se puede descubrir en los cuentos de las dos escritoras Wayuu una reducción del estatus privilegiado del idioma castellano; a pesar de ser el vehículo lingüístico a través del cual se narra los relatos, la constante incorporación de términos en Wayuunaiki demuestra la capacidad de este lenguaje nativo de mejor representar la realidad Wayuu. Como explican Deleuze y Guattari en la segunda parte de su definición, todo se vuelve político en la literatura menor. Se observa este fenómeno directamente en las denuncias abiertas y explícitas que enuncian los personajes infantiles de los cuentos de Siosi Pino y Simanca Pushaina. Muchas de estas quejas se manifiestan directamente hacia el Estado o a los funcionarios del Estado. Finalmente, una literatura menor es una que tenga un valor colectivo. En los cuentos Wayuu, la voz de los 
personajes (casi siempre niños) representa la colectividad de toda una población que también ha sido infantilizada, históricamente por los colonizadores y actualmente por la actitud paternalista de la sociedad hegemónica. ${ }^{24}$ Encontramos en los textos de las dos autoras Wayuu una inversión de significado mayor-menor. Lo menor se vuelve revolucionario y, por consecuencia, se convierte en lo mayor.

La teoría de Deleuze y Guattari reconoce una tensión entre las fuerzas mayores y menores, y señala que una literatura menor funciona y emerge desde el interior de un campo productivo establecido por la cultura dominante. De semejante forma, la teoría de Pierre Bourdieu sobre el campo de producción cultural será útil para entender el contexto en el cual estas dos autoras indígenas producen sus obras. Bourdieu, en su ensayo "The Field of Cultural Production, or: The Economic World Reversed" (1993), precisa que el campo literario o artístico es una zona de lucha constante en el cual varios agentes sociales participan en la transformación o conservación de dicho campo (30). Como toda literatura se produce dentro de un marco nacional, pretendo explorar cómo se ha incluido el imaginario Wayuu en el contexto nacional. Este intento de inclusión supone la existencia de un conflicto y una negociación subsiguiente entre los valores Wayuu y los criterios dominantes de lo nacional. Tal conflicto, como se verá con los intentos de categorización o encasillamiento de los cuentos de las dos escritoras Wayuu en el género de literatura infantil, demuestra las limitaciones impuestas por el campo de producción en que operan las autoras.

Para este mismo concepto, es útil considerar la teoría desarrollada por Benedict Anderson en su libro Imagined Communities: Reflections on the Origin and Spread of

\footnotetext{
${ }^{24}$ La infantilización del indígena se investigará más adelante en el capítulo 2.1 de este trabajo.
} 
Nationalism (1983). Según Anderson, una nación es una comunidad política imaginada y que, con la rara excepción de unos pueblos primordiales, toda comunidad humana existe como una entidad imaginada ya que los individuos nunca podrán conocerse entre todos (6). Explica que las comunidades se distinguen entre sí por el estilo en que uno las imagina. Esta teoría de Anderson es útil en una consideración de lo que significa la nación desde una perspectiva Wayuu, ya que muchos de los temas que se abordarán en este trabajo tienen que ver con una inclusión de las culturas indígenas. En Imagined Communities asimismo se reconoce el rol homogeneizador del lenguaje, refiriéndose a una propagación, lenta y geográficamente desigual, de unas lenguas específicas como instrumentos de una centralización administrativa por parte de algunos monarcas bien posicionadas (40). Con esta teoría se puede mejor acercarse a una visión sobre la intersección de idiomas que se percibe en todos los textos de Simanca Pushaina.

Por último, merece incluir algunos conceptos claves de la teoría del género literario ya que la hipótesis de este presente trabajo deriva de una valorización del género de literatura infantil. Hay que investigar las fuerzas que operan en el posicionamiento de una obra en una categoría y no en otra, y las posibles consecuencias sobre la recepción e interpretación de dicha obra. En el siguiente capítulo se desarrollarán estos conceptos e ideas sobre el género y lo que significa la asociación de los cuentos indígenas con una literatura menos canónica como la literatura infantil. Veremos que, en el caso de los cuentos de las dos autoras Wayuu, este acto de categorización circunscribe a la vez que les ofrece mayor libertad expresiva. 


\section{Capítulo 2 \\ Literatura infantil y escritura Wayuu}

A primera vista, los libros de Estercilia Simanca Pushaina y Vicenta Siosi Pino parecen fácilmente corresponder al género de literatura infantil, gracias a su sencillez estilística, el uso de un lenguaje libre de adornos excesivos, un formato breve como el del cuento corto, y su clara preferencia por narrar a través de personajes jóvenes. La hipótesis desarrollada a lo largo de este trabajo sugiere que las obras de las escritoras Wayuu no corresponden al género infantil, a pesar de todos los elementos que señalan el contrario. Para entender esta disconformidad, hay que analizar tanto las causas de la categorización infantil como las maneras en que se logra esta determinación. Hay que destacar, no obstante, que aunque el género literario y el texto no concuerden, la clasificación en dicho género y las diversas manifestaciones del concepto de paratexto siguen siendo influyentes y los cuentos de Siosi Pino y Simanca Pushaina terminan marcados e infantilizados. En este capítulo se examinarán primero las posibles causas de esta clasificación tendenciosa de las obras literarias de ambas autoras Wayuu y el injusto encasillamiento resultante. Asimismo, se presentarán varias de las considerables influencias que contribuyen a tal clasificación, enfocándose en el rol de los mediadores artísticos y analizando dichas influencias mediante una interpretación de los paratextos que acompañan cada obra. Finalmente se detallarán unos factores adicionales que pueden resultar en un auto-clasificación infantil, tales como las realidades de un mercado restringido de libros en Colombia y las posibilidades limitadas de reconocimiento para los escritores y escritoras de este país. 


\subsection{Infantilización de los indígenas}

En Colombia, la publicación de literatura infantil/juvenil de tema indígena se ha convertido en un verdadero fenómeno en las últimas dos décadas, según declara Juan Carlos Orrego Arismendi, antropólogo y profesor de la Universidad de Antioquia. De modo de explicación, ofrece lo siguiente: "Su formato ágil y la oportunidad que sirven de acceder a temas de la particularidad cultural americana han favorecido la difusión de esas obras en los planes de lectura escolar" (122). Es verdad que este género en particular se presta a una diversidad de temática contemporánea y relevante, y que su formato "ágil” facilita su producción y distribución, sobre todo cuando se conecta directamente con el mercado de libros escolares. Es más, como se expondrá al final de este capítulo, la literatura infantil también proporciona a los escritores cierta flexibilidad creativa y una libertad única de expresión. Sin embargo, hay que cuestionar la popularidad de estas "novelas de tema indígena dirigidas a jóvenes" y tratar de descubrir los factores subyacentes que contribuyen a esta fuerte asociación entre el indígena y el niño. Se propondrá en esta sección que estas concepciones pueden originarse en un antiguo tropo colonial - el del indígena como niño-que ha sido tan profundamente arraigado en la mentalidad y actitud de los latinoamericanos contemporáneos que quizás hasta los propios indígenas lo han internalizado.

A lo largo de la historia colonial en América Latina, la escritura ha sido el vehículo a través del cual se transmitía información sobre aquellas lejanas tierras y sus habitantes. En el discurso colonial, una de las imágenes que prevalece es la representación del indio infantilizado. Los europeos encontraron lo "infantil” en los indígenas del Nuevo Mundo en un intento de reconstruir un estado puro e inocente 
(Metz-Cherné 140). Según la perspectiva de los europeos, los nativos fueron unos salvajes que requerían protección, tutelaje y civilización. Como escribió Manuel Trino Morales en el primer editorial del periódico Unidad Indígena en 1975, “ya no nos dejaremos engañar por los explotadores de hoy en día que aunque digan que nos quieren como a hijos, no hacen sino quitarnos las tierras, nuestro idioma, nuestra religión y nuestras costumbres" (127). Los indígenas, hartos de escuchar el repetitivo discurso colonial de los "explotadores" que los tratan como si fueran niños, empiezan a organizarse. ${ }^{25} \mathrm{~A}$ través de sus esfuerzos unificadores, y gracias a las denuncias que surgen vía la literatura, estos "niños" exigen justicia y una reivindicación de su cultura y valores.

Según lo que explica Liz Conor en su artículo sobre la figura del "piccaninny", una imagen infantilizada y racializada proveniente del grupo aborigen de Australia, "childhood is deployed in colonial discourse to outline the lineage of inheritance, particularly in land tenure" (46). Conor describe que la infantilización del indígena ha sido una estrategia intencional por la parte de los colonizadores británicos con fines latentes de desheredarles a los nativos, así racionalizando la desposesión de sus "hijos" de su tierra (52) y los recursos que alberga. La presencia del tropo del nativo-como-niño es innegable en los escritos coloniales del siglo XIX:

These 'untutored children of nature' were said to undergo an 'arrest of development' wherein the Aboriginal mind developed until 12-14 years, but thereafter atrophied: 'They consequently remain, and will remain always, not animals, but little children, never advancing, and never

\footnotetext{
${ }^{25}$ Recientemente se ha observado un aumento en el interés en unificar los diversos pueblos indígenas de América Latina. Abya Yala, por ejemplo, es un movimiento contemporáneo pan-indígena; Según La Fundación Abya Yala (FAY), que fue creada por y para los pueblos indígenas de Centro, Sur América y México, "Abya Yala es el nombre con el que el pueblo Kuna de Panamá nombró al continente que ahora llaman América. Hoy día esta palabra se ha convertido en un concepto universal para los Pueblos Indígenas del subcontinente llamado Latinoamérica y otorga sentido de unidad y de pertenencia" (http://ayf.nativeweb.org).
} 
capable of cumulative advance, but living on unchanged till the conditions around them become too much for their limited powers, and then dying sadly out'. (Conor 51)

Este fragmento de Conor destaca varias representaciones de los indígenas que se han extendido a lo largo de la historia colonial y a través de los continentes afectados: el indio-niño, indio-salvaje, e indio-animal. Esta afirmación citada arriba demuestra también una actitud común compartida por los colonizadores, muchos de los cuales consideraban que los indígenas no poseían las mismas capacidades mentales que ellos, los "civilizados", revelando la creencia eugénica que el intelecto del nativo se "atrofiaba" después de la adolescencia. El caso australiano presenta muchas de las mismas características coloniales que se ha observado en América Latina. Esta actitud paternalista permitió que los colonizadores ampararan a los indígenas en una estrecha dependencia que sigue manifestando sus consecuencias hoy en día. En cuanto a la literatura, como nota Orrego Arismendi, resulta que en ella se ven reflejadas, y así perpetuadas, las idolologías y creencias de su época o su ambiente: "la plasmación idealizada del indio [ha sido] mimetizado por los escritores de ficción” (134). Es posible ver esta manifestación del tropo colonial en la categorización de las obras indígenas dentro del género infantil, una literatura menos apreciada y típicamente no incluida en el canon literario.

A pesar de su etiqueta infantil, las obras de Simanca Pushaina y Siosi Pino demuestran varios niveles de lecturas posibles y una diversidad de interpretaciones que rompen con las expectativas del género literario infantil. Es verdad que los personajes principales en los cuentos son niños y que el lenguaje tiende hacia la sencillez y, pero un análisis crítico de los textos revela un nivel de madurez que no corresponde con el 
género, tanto en los temas como en su técnica mañosa de denuncia. ${ }^{26}$ Una de las múltiples manifestaciones de resistencia en los cuentos de las autoras Wayuu es su inversión del tropo colonial del indígena infantilizado. No rechazan la categorización de sus obras como libros infantiles, sino asienten la plataforma que se les ha ofrecido y lo convierten en su propio campo de lucha, manipulando el espacio hasta que les convenga mejor. Esta apropiación y reconfiguración del discurso colonial por su propio beneficio es como poner "los pies en la cabeza", tomando prestada una imagen de Berichá, escritora del pueblo indígena u'wa de Colombia. ${ }^{27}$

Se puede proponer que estos cuentos funcionan como textos autoetnográficos, término que utiliza Mary Louise Pratt para señalar un texto en el que los individuos se comprometen a describirse a sí mismos de una manera que se interactúan con las representaciones que otros han hecho de ellos (35). ${ }^{28}$ En su ensayo, "Arts of the Contact Zone", Pratt también refiere al fenómeno de la transculturación, un término utilizado por etnógrafos para describir los procesos por los que se selecciona e inventa a partir de los materiales transmitidos por una cultura dominante o metropolitano (36). Basándose en esta definición, se puede sugerir que Simanca Pushaina y Siosi Pino participan en la transculturación al invertir las representaciones del indígena infantilizada,

\footnotetext{
${ }^{26}$ En algunos casos los personajes son animales, otra característica común en la literatura infantil, como se evidencia en el cuento "La señora iguana" de Siosi Pino. Aunque no se lo investiga profundamente en este trabajo, es interesante notar las representaciones de los animales en las obras escritas por o sobre la gente indígena. Refiérase al capítulo 3.3 de este trabajo y al artículo de Orrego Arismendi "El indio animal en dos novelas de Francisco Leal Quevedo" para ver unos ejemplos.

${ }^{27}$ Vea Los pies en la cabeza (1992), libro autobiográfico y autoetnográfico de Berichá, escritora u'wa originaria de la Sierra Nevada del Cocuy en los Andes orientales (Rocha Vivas, Textualidades 15).

${ }^{28}$ Pratt propone que la carta de Guamán Poma (datada en la ciudad de Cuzco, Perú, en el año 1913) es un ejemplo de un texto autoetnográfico. La primera parte de esta carta, más de 1200 páginas en total, se titula la Nueva Crónica. Según Pratt, este manuscrito es un ejemplo de invertir la representación "oficial" de la historia: "In writing a 'new chronicle,' Guamán Poma took over the official Spanish genre for his own ends. Those ends were, roughly, to construct a new picture of the world" (34).
} 
aprovechándose del lenguaje y el formato (el libro) que la cultura dominante les ha proporcionado. De igual modo, Efrén Tarapués Cuaical, escritor del pueblo de los pastos, quienes habitan el territorio pan-amazónico y andino, comenta la utilidad de la lengua castellana en cuanto a poder convertirla en arma contra los propios opresores (Rocha Vivas, Pütchi Biyá Jai II 135): “[...] dice saber leer porque quizá leyendo se conoce qué es que piensa el otro, cómo piensa, para qué piensa, y cómo este pensamiento o argumento sirve para nosotros" (142). Aquí el escritor indígena pastuso, igual que Calibán ${ }^{29}$ y asimismo Rigoberta Menchú, ${ }^{30}$ demuestra cómo tomar la lengua de los mismos opresores para convertirla en su propia arma. Siosi Pino y Simanca Pushaina, de manera similar, demuestran su propia insubordinación al adueñarse del género literario que se les ha establecido.

\subsection{El género literario y el rol de los "mediadores artísticos"}

Como se notó anteriormente, es esencialmente imposible que los lectores no sean conscientes del género literario de cualquier obra; por lo tanto, es igualmente inevitable que esta clasificación ejerza ciertas expectativas que influyen en su lectura de tal obra. Según las nociones sobre el paratexto expuestas por Gérard Genette, la declaración del género también representa una designación oficial: "This status [of genre] is official in

\footnotetext{
${ }^{29}$ En su ensayo "Calibán: Apuntes sobre la cultura en nuestra América", Retamar rechaza la visión de Ariel como símbolo de América Latina que había propuesto el escritor uruguayo José Enrique Rodó. En su lugar, propone que los latinoamericanos deben asumir su condición de Calibán, anagrama de Shakespeare a partir de la palabra "caníbal". Tomando los símbolos de La tempestad de Shakespeare (1612) y aplicándolos la revolución cubana, Retamar determina que es más adecuado el símbolo de Calibán, verdadero dueño de la isla y su único habitante que realmente se conecta con ella. El ensayo explica el papel del lenguaje y demuestra cómo Calibán lo convierte en su propia ventaja: "el deforme Calibán, a quien Próspero robara su isla, esclavizara y enseñara el lenguaje, lo increpa: 'Me enseñaron su lengua, y de ello obtuve / El saber maldecir. ¡La roja plaga / Caiga en ustedes, por esa enseñanza!'” (9)

${ }^{30}$ Vea el prólogo de Elisabeth Burgos-Debray del libro testimonial Me llamo Rigoberta Menchú y así me nació la conciencia: "Rigoberta aprendió' la lengua del opresor para utilizarla contra él. Para ella, apoderarse del idioma español tiene el sentido de un acto, en la medida en que un acto hace cambiar el curso de la historia, al ser fruto de una decisión: el español, la lengua que antaño le imponían por la fuerza, se ha convertido para ella en un instrumento de lucha" (9).
} 
the sense that it is the one the author and the publisher want to attribute to the text and in the sense that no reader can justifiably be unaware of or disregard this attribution, even if he does not feel bound to agree with it" (94). Genette explica que la forma en que uno presenta una obra literaria a sus lectores es tan importante e impactante como el texto en sí. Es más, su teoría acerca del género revela que la clasificación de una obra es definitiva e indeleble; es imposible que los lectores no se enteren de dicha atribución o que ignoren su existencia, aún si no están de acuerdo. Se da por entendido aquí que un autor no mantiene ningún control absoluto sobre sus obras literarias, ni tiene derechos exclusivos sobre las transformaciones que puedan afectar a su creación escrita. Se verá que también los mediadores artísticos, que pueden incluir la editorial, ilustradores u otros escritores, participan asimismo en la recepción de cada obra.

Antes de explorar el caso específico de los cuentos de Simanca Pushaina y Siosi Pino, es importante definir el género literario y mencionar alguna teoría relevante en cuanto al género específico de la literatura infantil. Para algunos teóricos contemporáneos como Jonathan Frow, el género literario es "a set of conventional and highly organized constraints on the production and interpretation of meaning [...] Generic structure both enables and restricts meaning" (10). Todos los elementos extra-textuales, tales como el género (o sencillamente la colocación en una u otra sección en la biblioteca o librería), la portada del libro y las ilustraciones, intervienen inevitablemente en las expectativas del lector, aún antes de leer la primera página. Amy Devitt advierte que las percepciones simplificadas de género fomentan las "mismas dicotomías en el estudio de la escritura que los investigadores contemporáneos de composición y retórica han sido socavando: las divisiones entre la forma y el contenido [...], productos y procesos, y el individuo y la 
sociedad" (5). ${ }^{31}$ En este sentido, se puede proponer que la forma en que el lector recibe los cuentos de las escritoras Wayuu, bajo el manto de la literatura infantil, resulta en una separación de o disociación con la literatura "alta" que suele componer el canon literario. ${ }^{32}$ Una de las consecuencias de la asociación con la literatura infantil es que no se suele definir las obras de esta categoría como una literatura "seria". Además, existe una fuerte asociación entre la literatura infantil y la fantasía o el escapismo, lo que puede llevar a un rechazo de su contenido y, por extensión, de su mensaje implícito. Aunque sirvan una función didáctica para los menores, desde la perspectiva de los adultos, puede ser difícil lograr que la tomen en serio. Frecuentemente se menosprecia a la literatura infantil a pesar de su contenido universal, lo que obstaculiza tanto a los lectores como a las escritoras en sus posibilidades de un amplio reconocimiento. Es más, como se verá en detalle más adelante, para escritoras como Simanca Pushaina y Siosi Pino, quienes imbuyen en sus textos una crítica social importante y en muchos casos urgente, un confinamiento de este tipo puede mermar la potencia de su mensaje.

Sin embargo, a la vez que el género limita, asimismo ofrece una plataforma única para desarrollar una expresión auténtica y libre. Peter Hunt mantiene que una de las delicias de la literatura infantil es que no se ajuste a ninguna categoría cultural ni académica; se encuentra, en consecuencia, por todas partes y en ninguna parte (citado en Westman 465). Además, como señala Karin Westman, o se elogia o se desdeña la

\footnotetext{
${ }^{31}$ Traducción mía.

${ }^{32}$ Aquí uso el término "literatura alta" en referencia a los conceptos de "high culture" y "popular culture" definidos de tal forma: "'Authentic' works of art and individual creativity and the aesthetic pleasures associated with their appreciation which require the demonstration of taste, discrimination, and sophistication derived from and contributing to the cultural capital of an elite as distinct from the 'mere entertainment' values associated with popular (mass) culture, commercial commodification and uncritical consumption. A polarizing term, originating in the mid-19th century, explicitly linked to class distinctions. However, Adorno and Horkheimer from the Frankfurt school offer a Marxist perspective in which high culture is a context within which dominant ideologies can be challenged" (Oxford Reference 2011).
} 
literatura infantil por tanta flexibilidad, generosidad y "omnipotencia” (465). Es precisamente esta flexibilidad que permite a que Simanca Pushaina y Siosi Pino adapten sus cuentos según les convenga y, como explicó Simanca Pushaina en una entrevista personal, "en los cuentos [uno puede] narrar algún elemento de la cultura, por ejemplo del encierro, de la identidad, del arraigo o del desarraigo". De igual forma, en el prólogo del libro El dulce corazón de los piel cobriza (2002), Pérez van-Leenden explica que es el "género que le brinde la comodidad para decir de la mejor manera" en el cual pueden aparecer diversos temas como el desarraigo, la mimesis y la vergüenza étnica (10). El cuento es conciso y enfocado, lo que facilita una exploración profunda con amplias posibilidades para expresar unos conceptos culturales específicos y para cumplir con sus funciones didácticas y críticas.

Por lo tanto, el campo de literatura infantil puede representar un buen ambiente que permite que las autoras Wayuu se expresen plenamente. Rocha Vivas, por ejemplo, considera que este espacio particular es quizá el más adecuado para la expresión escrita de los indígenas debido a su conexión con la oralidad; en su libro Palabras mayores, palabras vivas, el autor propone una ampliación de nuestras prácticas y concepciones de la literatura. (28) Además, en este mismo libro, Rocha Vivas razona que la llamada literatura infantil es mucho más flexible y creativa para estos fines (de ampliar o reorientar las conceptos de nuestra literatura), mientras que "la literatura 'adulta' [...] parece más apegada a sus sistemas de referencias escritas y leídas" (Palabras mayores 28-29). No obstante, la clave de la rebelión de Simanca Pushaina y Siosi Pino yace en la manera en que transforman el género literario; juegan con los espacios y estereotipos que otros les han asignado para convertirlos en herramientas de resistencia. 
Al analizar el género de una obra escrita, hay que reflexionar también sobre la influencia de los agentes que determinan la clasificación. Es conveniente aplicar el término de Pierre Bourdieu, "mediadores artísticos", para referir a todos los que influyen en el significado y valor de cada obra (11). Según lo que expone Bourdieu en su ensayo crítico, es imprescindible reconocer el potente impacto que estos individuos o grupos (los editores, críticos, academias, etc.) ejercen en la valorización de una obra (sea literaria o artística). Aparte del artista o escritor que produce el texto escrito, también intervienen estos mediadores en la producción del significado y la valoración de la obra; todos estos agentes se esfuerzan en una tarea colectiva para promover la recepción del libro como “arte” (37). Por esta razón, en el análisis de los cuentos de las escritoras Wayuu, se debe considerar que, aparte de lo que ellas escriben y cómo escriben, existen dentro del campo de su producción artística muchos agentes exteriores que influyen en la recepción de sus obras. En muchos casos, estos agentes se hacen visibles a través de los paratextos que típicamente acompañan a los textos escritos, sobre todo cuando estos textos se convierten en libros por vía del proceso editorial.

\subsection{Interpretación de paratextos}

Todo el empaque exterior y el conjunto de elementos paratextuales, lo que Philippe Lejuene describe como el "fleco" de un texto, ayuda a apoyar esta apreciación como libro infantil..$^{33}$ La portada, por ejemplo, del libro El encierro de una pequeña doncella (2003) de Simanca Pushaina, demuestra una imagen indudablemente dirigida hacia un público de niños (figura 4). Este cuento detalla la experiencia de una joven

\footnotetext{
${ }^{33}$ Este término-el "fleco"- (la frange en francés) y la teoría de Lejeune son desarrollados en su libro Le Pacte autobiographique de 1975 y referenciados en Paratexts por Genette. En la cita extendida, comenta sobre el poder de este supuesto adorno que suele ser subestimado: "[the paratext is] a fringe of the printed text which in reality controls one's whole reading of the text" (citado en Genette 2).
} 
Wayuu que se encuentra repentinamente (y hasta violentamente, según las revelaciones de la narradora) enclaustrada al empezar su primera menstruación. El cuento se narra desde la perspectiva de una niña que, al principio, parece no entender que ella participa en un rito de paso tradicional durante el cual se transformará en mujer. Es verdad que la temática puede ser relevante y reveladora para los lectores adolescentes; por ejemplo, el cuento brindaría una perspectiva original o alternativa a las jóvenes en la misma etapa de desarrollo entre niña y mujer. La lectura de este cuento les podría ofrecer una oportunidad de reflexionar sobre su propia experiencia en la fase de pubertad y el significado de este momento crucial. Sin embargo, se pone en peligro la posibilidad de que esta joven lea el cuento, debido en parte al diseño de la portada que da la impresión de un contenido más infantil.

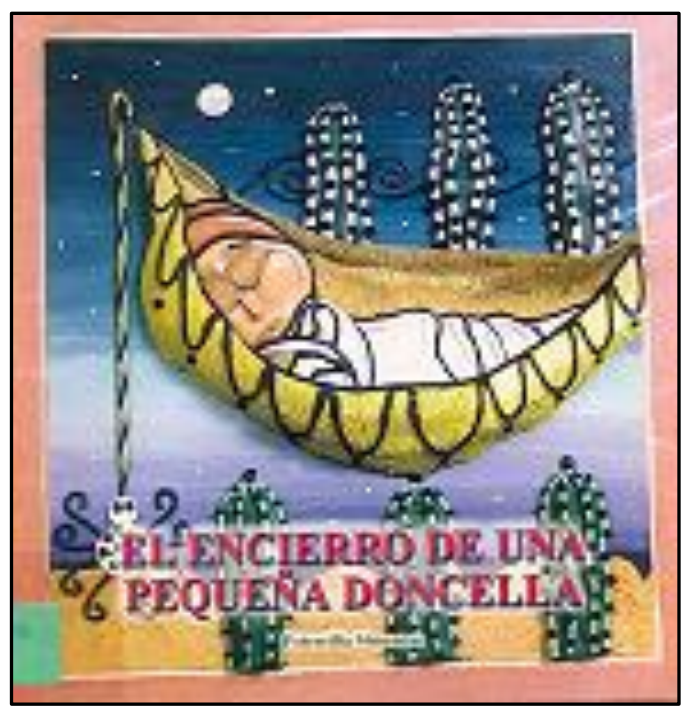

Figura 4: Portada infantil del libro El encierro de una pequeña doncella (2003). (Artista: Hernández Rincón)

Basándose en las definiciones de Genette, la portada es dominio de las editoriales y, en consecuencia, puede operar por fuera del texto en sí. Los niveles de control y colaboración entre las escritoras Wayuu y los editoriales varían ampliamente; Este hecho se ve evidenciado en la discordancia de las portadas e ilustraciones según quién mantuvo la autoridad sobre la apariencia de cada publicación. En el caso de su primer libro sobre el encierro, la autora Simanca Pushaina, no hubo ninguna colaboración en el diseño de su primer libro: "A mí me dijeron que me publicarían el libro, meses después me invitaron a conocer el libro ya hecho. A Mauricio [Hernández Rincón, artista que diseñó la portada y 
los demás ilustraciones] lo conocí en el lanzamiento, en Riohacha" (entrevista personal). Para justificar una teoría sobre la discordia, basta comparar la portada anteriormente referenciada del cuento "El encierro de una pequeña doncella" con la del folleto "Manifiesta no saber firmar. Nacido: 31 de diciembre" (figura 5), relato que, a pesar de

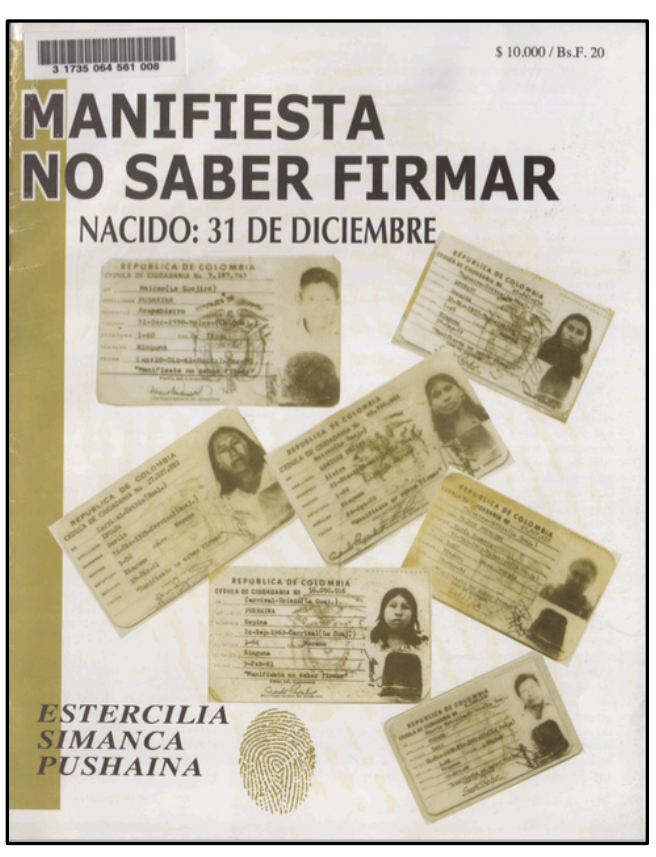

Figura 5: Portada del cuento "Manifiesta no saber firmar. Nacido: 31 de diciembre" (versión de la autora, 2006) narrarse de la voz de una niña, revela una fuerte denuncia a los vejámenes cometidos por los políticos de turno en contra los Wayuu. En este último ejemplo, tanto el exterior (portada y contraportada) como el interior (el texto, fotos, imágenes, autobiografía) del folleto fueron dominio total de la propia autora. Al comparar estas dos portadas contrastantes, es evidente que el encasillamiento de los cuentos de Simanca Pushaina tiene más que ver con las fuerzas exteriores que con su propia voluntad.

De igual forma, las ilustraciones que acompañan los textos de Simanca Pushaina y Siosi Pino muestran una incoherencia con el género que se les ha asignado. Con el fin de analizar una instancia representativa, se observa en el libro de cuentos de Siosi Pino una contradicción de imágenes: unas parecen diseñadas para un lector infantil (figura 6) mientras que otras, como la que acompaña al cuento "No he vuelto a escuchar los pájaros del mundo", son claramente distintas en su propósito (figura 7). La ilustración de este último ejemplo pinta una escena impactante de una joven, evidentemente la narradora del cuento, con el marido mayor, claramente embriagado y medio desnudo a su lado. La 
expresión de la joven, recién casada y atrapada, revela un dolor profundo e innegable. Aquí ya se aproxima a una clasificación esencialmente opuesta para el cuento-no apto para niños-según las consideraciones tradicionales de lo que es apropiado o no en la literatura infantil, aunque esta determinación en sí misma es también nebulosa y subjetiva.

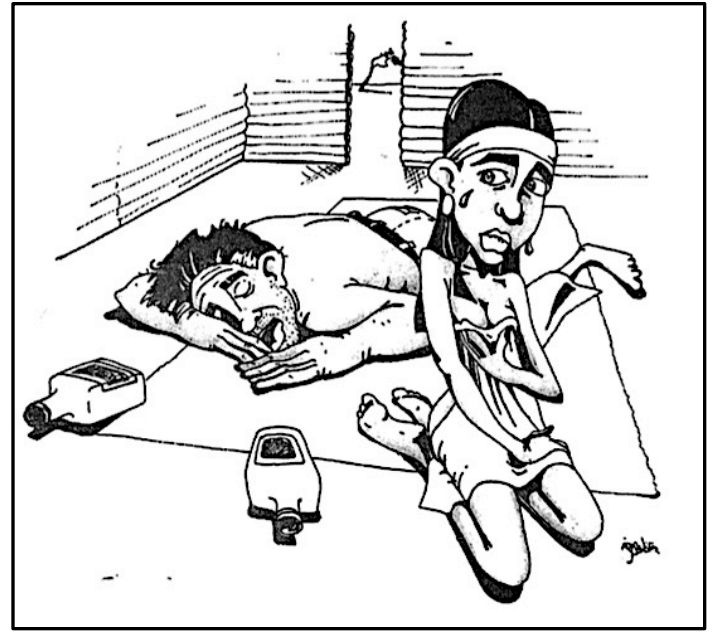

Figura 6: Ilustración que acompaña al cuento "No he vuelto a escuchar los pájaros" (Siosi Pino, Dulce corazón 99) Ilustrador: Rafael Rojas Neira

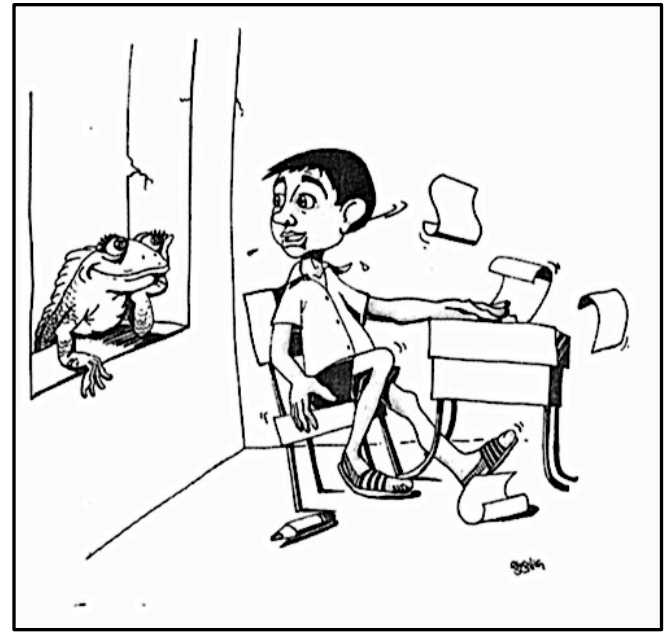

Figura 7: Ilustración que acompaña al cuento "La señora iguana" (Siosi Pino, Dulce corazón 91) Ilustrador: Rafael Rojas Neira

Junto con las portadas e ilustraciones, el prólogo, o cualquier otro tipo de introducción textual que se incluye antes del inicio del texto principal, también puede interceder en la manera en que un lector aprecia la obra entera. El prólogo es frecuentemente escrito por otras personas, lo que señala que estos autores adicionales también pueden clasificarse como otros ejemplos de "mediadores artísticos". Para dar un ejemplo representativo, si un lector lee la indicación en el prólogo del libro El encierro de una pequeña doncella, las palabras influirán indudablemente en su interpretación de esta obra: "Comfamiliar del Atlántico busca con esta publicación, seguir contribuyendo con nuestra literatura infantil, e impulsar a nuevos escritores de este género y ofrecerle a 
nuestros niños más libros, que los adentren en el mundo de fantasía” (s.p.). Se nota que, apenas abierto el libro, el lector ya tiene información que participará en moldear su lectura de tal cuento y contribuirá a sus percepciones generales de su mensaje y función literaria. El concepto del paratexto elaborado por Genette describe el prefacio de un libro como un vestíbulo que ofrece a los lectores la posibilidad de entrar o retroceder (2). Por consiguiente, si un lector busca un libro infantil, si le atrae la portada que demuestra a un bebé, durmiendo felizmente en su cuna/hamaca, si le interesa "adentrarse en el mundo de fantasía", seguramente querrá pasar por el vestíbulo y "entrar" en el cuento. No obstante, si el lector prefiere una literatura que agrade a la vez que le haga reflexionar, que critique mientras poetice, es factible que no atraviese ese vestíbulo. Por lo tanto, aunque el cuento de Simanca Pushaina cumple con todas esas funciones, tal como debe un buen libro, el lector hipotético no tendría acceso a este cuento porque todas las influencias externos habían edificado tantas barreras.

El breve prólogo del libro sobre el encierro Wayuu cumple varias funciones que evidentemente operan externamente al texto en el ámbito del paratexto: Primero, declara el género (literatura infantil); segundo, define el público (niños); y finalmente clasifica el contenido temático (fantasía). Genette explica que la función principal de un prefacio original es de asegurar que se lea el texto correctamente (197). Si se toma en cuenta estas indicaciones y las aplicamos asimismo al prólogo, hay que sospechar una marcada discordancia entre la editorial que busca encasillar el texto "El encierro" como un cuento infantil y la autora misma que, si fuera decisión suya, colocaría más bien "apto para todo público". Simanca Pushaina declara que sus cuentos "No deberían ser clasificados como infantiles [de] verdad, pero si eso es lo que cree el público lector yo los dejo. Considero 
que la literatura no tiene jurisdicción ni edad" (entrevista personal). Aparte de lo que se presenta a través del paratexto, existen más características en los cuentos de ambas escritoras que añaden a su (mis)clasificación como libro infantil: la mayoría de los personajes son niños, el estilo la escritura es minimalista y el lenguaje es sencillo. No obstante, un lector erudito no debería dejarse engañar por la mera apariencia exterior ni por la sencillez humilde de la narrativa. Además, hay que recordar que los lectores tienen el derecho de leer un texto como se les considere conveniente. Como este trabajo propone elucidar, los cuentos de Simanca Pushaina y Siosi Pino se prestan a múltiples interpretaciones y diversos niveles de lectura, lo que en efecto es una de las características más fundamentales de una obra maestra.

Para ofrecer una comparación, el prólogo de la colección de cuentos El dulce corazón de los piel cobriza (2002) es distintamente más académico y menos infantil que el ejemplo anteriormente analizado de El encierro de una pequeña doncella (2003). Con el fin de presentar los cuentos de Siosi Pino, el profesor y lingüista Francisco Justo Pérez van-Leenden ofrece un prólogo que pretende contestar de antemano algunas de las preguntas que el lector imaginado tendría al iniciar la lectura. De esta forma contesta varias curiosidades hipotéticas, tales como “¿Por qué escribe Vicenta María?” (5) y “¿Por qué cuentos?" (10). En esta introducción a los cuentos de Siosi Pino se encuentra una cantidad de incongruencias que podría chocar al lector y que seguramente complica la categorización del libro; no está tan claro si se trata de literatura para niños o si es simplemente literatura. A la vez que refiere a conceptos avanzados y a varios teóricos, intelectuales, lingüistas y filósofos (Jean Paul Sartre, Estanislao Zuleta, Antonio Gramsci, Mario Vargas Llosa, entre otros), Pérez van-Leenden entrelaza sus ideas con una 
abundancia de expresiones locales-“como dicen los pelaos" (6) -y jerga regional-“le 'picó' el bicho o de leer o de escribir y esa vaina es pa' siempre” (7). Hasta el prólogo demuestra un tipo de lenguaje híbrido; un mestizaje único de creación escrita. No es muy común leer un texto así, tan revuelto: Pérez van-Leenden cita a Sartre (5) y en el próximo párrafo refiere a lo "corroncho" (6). Tal vez esta tendencia es un intento más de explorar el sincretismo en tanto en la región de La Guajira como en la literatura. Como lo explica Pérez van-Leenden, el aporte de Siosi Pino "a la cultura y a las letras colombianas está en ir en la oleada que abre un espacio para la lecto-escritura de sentidos y contenidos típicamente mestizos, interculturales" (7). Viendo estas supuestas discordancias o incongruencias del prólogo de otra forma, es posible vislumbrar otra opción: una renovación de la literatura que mejor refleja una nueva realidad intercultural.

Esta idea se desarrolla más profundamente en el artículo de Marisol de la Cadena y Orin Starn, "Indigeneidad: problemáticas, experiencias y agendas en el nuevo milenio", en el cual recomiendan cambiar la producción de conocimiento, realizando en su lugar “un género híbrido que fuera a la vez académico y no académico, local y universal, y comprometido con la borrar las diferencias entre esas esferas a la vez que interviene en todas ellas" (217). Lo que se percibe no solamente en el prólogo arriba mencionado, sino también en los textos en sí de las escritoras Wayuu, es precisamente un ejemplo de este género híbrido propuesto por de la Cadena y Starn. Es más, en comparación con el prólogo de El encierro de una pequeña doncella, que parece arrinconar la obra de Simanca Pushaina en un entorno infantil, Pérez van-Leenden ofrece a la obra de Siosi Pino un nivel más alto de prestigio intelectual y afirma su valor literario. Por influencia de este prólogo, el propio vestíbulo a través de lo cual los lectores pasarán antes de 
conocer el primer cuento de la colección, éstos ya habrán empezado a establecer expectativas y juicios acerca de los relatos y su mérito literario.

Aparte de los prólogos, la manera en que se presenta la información biográfica expone detalles significativos que merecen atención. Por ejemplo, es interesante que no aparezca el nombre completo de la autora (Estercilia Simanca Pushaina) en la portada ni en la página inicial al interior de la tapa. La editorial ha optado por eliminar el apellido Pushaina y en su lugar aparece "Estercilia Simancas" ${ }^{34}$ Este hecho es especialmente significante porque este apelativo "Pushaina" señala el nombre de su clan Wayuu y representa su linaje indígena. En cuanto a la biografía, se ofrece escasa información acerca de la autora: “Abogada. Nació el 10 diciembre de 1975 en la Ranchería Indígena Wayúu El Paraíso, Resguardo Indígena de Caicemapa, Municipio de Distracción (Baja Guajira)" (s.p.). La biografía parece más una indicación geográfica que una descripción de la vida y los logros de tan talentosa mujer. Sin embargo, Simanca Pushaina confirma que ella misma escribió la biografía pero que no tenía nada más que agregar (entrevista personal). Es curioso notar que la primera palabra que aparece en dicha biografía es "Abogada" mientras que en su propia edición de otro cuento, "Manifiesta no saber firmar. Nacido: 31 de diciembre”, publicado cinco años después en 2008, el término que Simanca Pushaina prefiere para abrir su biografía es su identificación étnica: "Wayuu”. Lo que sigue en la autobiografía es una larga lista de méritos y premios, indicativo de una creciente confianza y su rápido desarrollo como escritora. La autora ya no tiene miedo de representarse tal como es, como indicó en una entrevista de 2006 con María Cristina

\footnotetext{
${ }^{34}$ Cabe notar que también se ha escrito incorrectamente Simanca en esta edición del libro-aparece con una "s" al final del apellido - hecho que la autora afirma no le importa ni le molesta. Vea el Apéndice A para la entrevista con Simanca Pushaina en donde se comenta esta incongruencia.
} 


\section{Rincón y Janeth Chaparro:}

Aquí el problema no es de oportunidades sino de justicia. Aquí hay muchas hermanas wayuu que son abogadas y se dedican a su profesión, algunas escriben pero no han dado a conocer sus creaciones, tal vez por miedo, miedo que yo también tuve al principio, pero después me solté. Soy rebelde y nada me da pena. (Citado por Rocha Vivas en Palabras mayores 204)

Así que parece que la autora del año 2003, la que no sabía sobre qué escribir en su biografía, es la versión de una escritora todavía emergente, una que duda de sus propias capacidades. Cabe notar que es esta misma escritora que dejó que su cuento se clasificara

como infantil y que dejó que se diseñara e ilustrara todo el libro sin participar en el proceso hasta ver el resultado al final. Y aunque ella dice que no le molesta, el cuento "El encierro de una pequeña doncella" fue el catalizador que encendió su carrera literaria y de este modo empezó su trayectoria en el mundo de literatura infantil.

\subsection{Realidades de un mercado restringido}

Las posibilidades para ganarse la vida en Colombia a través de la escritura y publicación de literatura (infantil u otra categoría) son bastante limitadas. Siosi Pino, en una entrevista, describe la manera en que logró publicar su primer cuento:

Desde el año 92 cada [cuento] fue publicado independientemente, pero después yo hice una complicación con el apoyo de la Asociación de Autoridades Tradicionales de mi ranchería. Este libro lo publicamos con préstamo que pedí al banco, ellos me hicieron el préstamo y luego yo tuve que devolver la plata, y el libro se vendió. (Duchesne Winter 433)

Se puede entender, entonces, que las dos autoras publican la mayoría de sus obras de forma independiente; si reciben alguna aportación de dinero, típicamente viene de una organización cultural de la Guajira, uno de los muchos departamentos colombianos cuyos recursos son extremadamente limitados. No obstante, como se evidencia en la entrevista 
de Siosi Pino arriba citada, los Wayuu se apoyan entre sí; gracias a su propia comunidad, Siosi Pino y Simanca Pushaina han podido seguir escribiendo e intentando publicar. Además, considerando la teoría de Pierre Bourdieu sobre la inversión del mundo económico, se percibe otra problemática única al campo de producción literaria o artística en que las posibilidades de los escritores o artistas de adquirir capital económico son severamente circunscritas a pesar de poseer altos niveles de capital simbólico, sea académico o cultural (39-40). Entendidos estos conceptos, se podría proponer que el género de literatura infantil ofrece a las dos escritoras las mejores oportunidades para publicar sus obras y obtener alguna compensación monetaria a la vez que les permite la opción de seguir con su vocación. Es más, en el caso de ambas escritoras Wayuu, el apoyo económico y el reconocimiento conferido a través de su éxito en el campo literario infantil, le han facilitado su incorporación en el ámbito académico para difundir su mensaje crítico a diversos lectores.

Para entender esta teoría en su aplicación específica al campo de producción, primero es importante describir brevemente la situación del lectorado en Colombia. En su artículo, “Once Difficult, Never Impossible: The Colombian Book Market”, María Villegas ofrece la siguiente estadística, desconcertante para los escritores nativos de ese país: "With nearly 50 million inhabitants - of which $37 \%$ report that they read for pleasure and $24 \%$ because of their academic demand, [...] Colombia has one of the lowest indices of reading in the world: 1.9 books per person each year" (64). Tomando estas cifras y combinándolas con el analfabetismo que se extiende por regiones específicas, sobre todo entre las comunidades indígenas, se entiende que el número de lectores posibles es mucho más reducido en comparación con otros mercados nacionales. 
Villegas describe las dos oportunidades principales por las cuales un texto infantil típicamente logra llegar a un mayor número de lectores:

Referring to the children's books market in particular, there are two large segments: the "set" or "prescribed" books and those on the open market. The first - known as "prescribed" books in Spanish (libros de prescripción) - are those which private high schools and some public ones ask their students to buy, as a complement to their course of studies, and amount to about six books per year for each student. The second-books in the open market - are aimed at the general public. (66-67)

Por lo tanto, Villegas confirma que en Colombia, los dos segmentos más grandes del mercado de literatura infantil incluyen los libros de prescripción, designados a los lectores colegiales, y los demás, dirigidos al público general. Aunque es verdad que algunos colegios y universidades incorporan los textos de las dos autoras Wayuu en su plan de estudios, según explica Simanca Pushaina, "nos invitan porque el profesor de literatura nos conoce o nos ha leído y porque en mi caso particular promociono mi blog a través de las redes y tengo mucho seguidor joven. Pero incorporados en el plan de estudio no, más bien como actividades extracurriculares” (entrevista personal). Debido a estos factores-el analfabetismo, un número reducido de lectores por ser clasificados como cuentos infantiles, la falta de apoyo por la parte de los institutos escolares, recursos limitados para los libros en general-ambas escritoras han experimentado con formas alternativas para que su mensaje alcance al público. Simanca Pushaina mantiene su blog, por ejemplo. En el caso de Siosi Pino, que no ha publicado ningún libro desde $2002,{ }^{35}$ ha optado por publicar por lo menos en una ocasión notable a través de otros medios de comunicación tales como la prensa, lo que se puede evidenciar con su carta al presidente

\footnotetext{
${ }^{35}$ Según una entrevista de 2009, escrita por Jaime de la Hoz Simanca, Siosi Pino está en el proceso de escribir su primera novela. En una entrevista personal con Miguel Rocha Vivas, que tuvo lugar el 17 de febrero de 2016, se confirma que la autora todavía sigue con este proyecto.
} 
Santos en 2012. ${ }^{36}$

A pesar de todo, la categorización dentro del género de la literatura infantil sí brinda ciertas ventajas a las dos escritoras. Por ejemplo, al ser etiquetados como infantiles, tanto los cuentos de Simanca Pushaina como los de Siosi Pino han ganado numerosos premios literarios y han recibido bastante reconocimiento público y crítico, por lo mismo dentro del propio mundo de literatura infantil/juvenil. Por ejemplo, en 1998 Siosi Pino participó en el Concurso Enka: Premio Andino y Panamá de Literatura Infantil y ganó una mención de honor con el cuento "El dulce corazón de los piel cobriza" (figura 8). Luego, en 2000, ganó el primer puesto en el Concurso Nacional de Cuento Infantil, convocado por

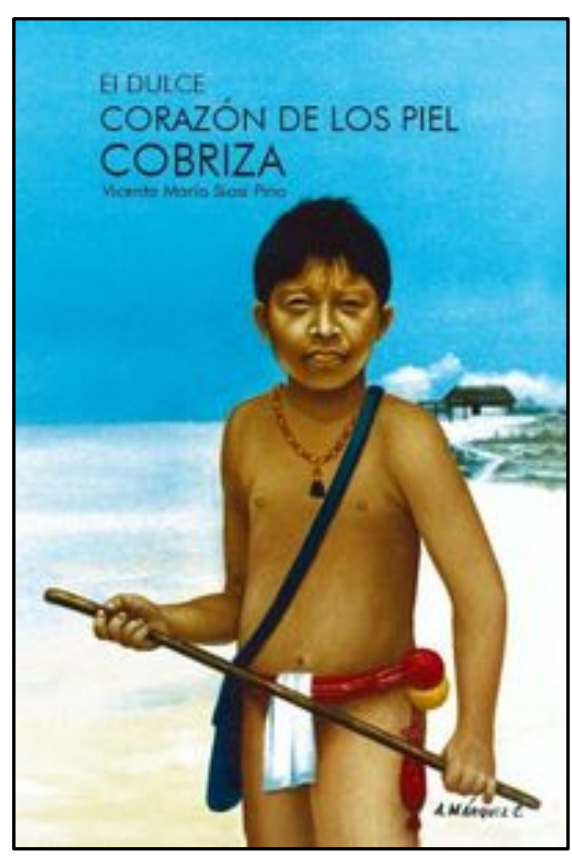

Figura 8: Portada del libro $E l$ dulce corazón de los piel cobriza (Siosi Pino, 2002) Comfamiliar del Atlántico, con "La señora Iguana”. En cuanto a Simanca Pushaina, ella también ha recibido apreciaciones bien merecidas en ciertos concursos de literatura infantil: su cuento "El encierro de una pequeña doncella" llegó a ser finalista en 2003 en el mismo Concurso Nacional de Cuento Infantil del Comfamiliar del Atlántico y fue incluido en la lista de honor del IBBY (International Board on Books for Young People). Se puede conjeturar que, sin publicar en formato infantil, las dos escritoras Wayuu no hubieran adquirido el mismo nivel de éxito ni hubieran recibido tanto reconocimiento.

\footnotetext{
${ }^{36}$ También se ha publicado la carta de Siosi Pino al presidente Juan Manuel Santos en el blog de Simanca Pushaina y en diferentes medios de comunicación como el diario El Espectador. Vea el apéndice B para el texto completo de esta carta.
} 


\section{Capítulo 3 \\ Análisis textual: Denuncia e intentos de reconciliación}

Las dos escritoras Wayuu que forman el enfoque central de este trabajo, Vicenta

Siosi Pino y Estercilia Simanca Pushaina, son indígenas contemporáneas y, en ambos

casos, mestizas. Siosi Pino, Wayuu por vía materna, recibe su apellido de su bisabuelo,

un comerciante italiano. ${ }^{37}$ Simanca Pushaina es hija de una Wayuu y padre alijuna (no

Wayuu). Ninguna de las dos habla Wayuunaiki y ambas escriben exclusivamente en

castellano. ${ }^{38}$ A la vez que ellas reclaman una apreciación de los valores ancestrales

Wayuu, reconocen la importancia de la innovación e implementan técnicas modernas

para expresar sus demandas. Es más, las dos son mujeres que ejercen múltiples

profesiones. Aparte ser escritor, Siosi Pino también ha trabajado como corresponsal, jefa

de la presa de la Gobernación de Guajira, libretista, profesora universitaria y

documentalista para televisión (Rocha, Pütchi Biyá Jai I 101).

Asimismo, Simanca Pushaina, como ella misma se define en el folleto que

publicó de su cuento "Manifiesta no saber firmar. Nacido: 31 de diciembre", es abogada

en ejercicio, investigadora cultural, y escritora de temas propios de la cultura Wayuu

(edición de la autora 11). Cabe mencionar que Simanca Pushaina también es diseñadora

de textiles de influencia Wayuu y empresaria de una marca de ropa étnica-moderna, Casa

\footnotetext{
${ }^{37}$ Según el costumbre Wayuu, Vicenta Siosi Pino debió heredar el apellido Apshana de su bisabuela (de la Hoz Simanca s.p.). Vea también su cuento "El honroso vericueto de mi linaje," relato claramente autobiográfico que explora la sucesión de mujeres wayuu en la historia familiar de la narradora. ${ }^{38}$ Aunque no habla Wayuunaiki, Simanca Pushaina se ha comprometido a defender los derechos lingüísticos del pueblo Wayuu: "exijo que hasta las razones sociales de las entidades estén escritas en fonemas Wayuu, de hecho ese será mi próximo paso a seguir, ejercer la oficialidad del idioma Wayuu en el departamento de La Guajira [...] hay muchos Wayuu que no hablan español y necesitan hacer sus trámites, es necesario y yo tengo las herramientas para que sea una realidad" (entrevista personal).
} 
Julirü, cuyas mantas son diseñadas específicamente para las mujeres no Wayuu. ${ }^{39}$ Igual como en sus vidas personales, asimismo en las obras de Siosi Pino y Simanca Pushaina aparece el intento de reconciliar una problemática indígena de la actualidad: ¿cómo ser indígena y mestiza (y moderna) al mismo tiempo?

Para Marisol de la Cadena y Orin Starn, la perspectiva de mestizaje es fundamental: "Compartimos una visión de mezcla, eclecticismo y dinamismo como esencia de la indigenidad en oposición a una caída o ‘corrupción’ de algún estado de pureza original" (195). Es decir, los grupos indígenas se han modernizado y siguen evolucionando según parece necesario, conveniente, o ventajoso, en muchos casos. En su artículo "Indigeneidad: problemáticas, experiencias y agendas en el nuevo milenio", de la Cadena y Starn comentan esta búsqueda, por la parte de los pueblos indígenas, de definirse a sí mismo en contra "la densa maraña de símbolos, fantasías y significados de la indigenidad" (195). Estos autores describen que los límites o características que definen un individuo como indígena no son concretos ni intrínsecos y reconocen la necesidad de reconceptualizar la indigenidad en términos que no se basen en lo que no es o lo que le falta (196).

El teórico peruano, Antonio Cornejo Polar, medita sobre el concepto de un sujeto híbrido latinoamericano en la introducción a su libro ensayístico Escribir en el aire. Cornejo Polar se pregunta si realmente podemos hablar de un sujeto único o totalizador, o

\footnotetext{
${ }^{39}$ En la página web de su marca Casa Julirü, palabra que significa "mariposa" en Wayuunaiki, aparece el siguiente comentario de la autora: "A nosotras nos enseñan desde niñas a usar las mantas hasta los pies. Los arijunas en el pasado miraban a las doncellas de ayer extrañados por arrastrar sus mantas. A ellas eso no les importaba, entre más larga mejor, era señal de prestigio. Yo, particularmente las uso larga, bien largas. Con el tiempo entendí por qué no debo mostrar mis pies... Quien quiera ver mis pies debe primero debe encontrar las huellas que mi manta atenúa con cada paso que doy”. Refiérase a la página web de Casa Julirü: http://julirucolombia.blogspot.com.
} 
si “deberíamos atrevernos a hablar de un sujeto que efectivamente está hecho de la inestable quiebra e intersección de muchas identidades disímiles, oscilantes y heteróclitas” (21). El teórico propone en este ensayo que el concepto de la heterogeneidad, tanto en la literatura como en la cultura andina, es el único adecuado para describir la realidad de la identidad latinoamericana, debido a su larga historia de interacciones multiculturales y procesos transculturales. Asimismo, en el prólogo al libro El dulce corazón de los piel cobriza, Francisco Justo Pérez van-Leenden refiere al mestizaje como una construcción social. Comenta que hay personas, "especie de 'anfibios culturales ${ }^{\top 40}$ que conocen y viven perfectamente dos códigos lingüísticos y dos cosmovisiones" (8). La teoría expresada aquí tiene varias interpretaciones con múltiples denominaciones. Se encuentra, por ejemplo, el concepto de "edgewalkers" elaborado por Nina Krebs en su libro Edgewalkers: Defusing Cultural Boundaries on the New Frontier (1999). En este texto, Krebs explica que los "edgewalkers" (individuos que caminan "al borde", típicamente entre dos o múltiples culturas) operan desde por lo menos dos estructuras de creencia y suelen entender cuando pasan de una a la otra. Además, la autora afirma que estos "edgewalkers" reconocen que ningún sistema tenga todas las respuestas y por esta razón se encuentran en una posición perfecta con las herramientas necesarias para construir una nueva realidad (62). Este posicionamiento de "entre mundos" permite que las autoras perciban y logren describir una realidad intercultural y moderna a la vez.

Por consiguiente, tiene mucho sentido que la literatura de Simanca Pushaina y

\footnotetext{
${ }^{40}$ En su prólogo, Pérez van-Leenden explica que esta idea de los "anfibios culturales" proviene de Antanas Mockus (expresada por Jon Landaburu); el texto no incluye más información bibliográfica sobre esta referencia (Dulce Corazón 8).
} 
Siosi Pino también demuestre igualmente algunas cualidades de hibridez. Sus maneras de exponer sus denuncias y críticas son innovadoras también; se verá que sus denuncias, aunque son directas, fuertes, y muchas veces muy poco disimuladas, no adhieren al formato del testimonio (popular entre otras escritoras latinoamericanas) ni son ensayos políticos. Es más, como ya se ha expuesto, tampoco corresponden a lo que se suele esperar de un texto infantil. Se puede proponer que el mestizaje, un concepto tan señalado y fundamental a la construcción de la identidad latinoamericana, aparece de igual modo en la literatura de las dos autoras Wayuu. Su universo y sus obras se interactúan y se alimentan en un intento de representar-y criticar-su realidad actual. En las siguientes secciones se expondrán las varias manifestaciones de crítica y denuncia como aparecen en las obras de Simanca Pushaina y Siosi Pino.

\subsection{Críticas abiertas}

En los cuentos de ambas escritoras Wayuu se percibe una variedad de técnicas al desarrollar su arte y, a la vez, maneras de expresar su denuncia. Mientras que los textos contienen diversos trucos narrativos que revelan una disconformidad de manera sutil o disimulada, hay también numerosos casos de una crítica más directa y así innegable. El relato quizá más conocido de Estercilia Simanca Pushaina, "Manifiesta no saber firmar. Nacido: 31 de diciembre", es el ejemplo idóneo de estas críticas abiertas. En este cuento, una narradora de 7 años, niña Wayuu, relata una historia en que su realidad indígena choca bruscamente con el mundo de los alijuna. Narrado en primera persona, con la voz de una niña y desde su perspectiva, el cuento describe la manipulación y burla de los funcionarios del Estado quienes, en su afán por cedular a los indígenas para convertirlos en votantes oficiales, los rebautizan con nombres ofensivos y declaran que todos nacieron 
el 31 de diciembre. La narradora, cuyo nombre (Coleima Pushaina) no se menciona hasta casi el final del cuento, demuestra sus altos niveles de percepción a lo largo de la narrativa. Es capaz de distinguir y reflexionar sobre los engaños y la actitud irrespetuosa de los políticos de turno, incluso cuando los adultos Wayuu no perciben la misma realidad.

Coleima, personaje que más probablemente revela la experiencia de la propia autora, exhibe su propia ingenuidad, más la ternura inocente de una niña pequeña, al principio del relato: “creí que todos los Pushainas nacían [el 31 de diciembre], les prometí a todos que cuando yo creciera haría una fiesta de cumpleaños a todos los Pushainas que habitaban en la península de la Guajira” (411). En este primer capítulo de la obra, que funciona como un tipo de introducción al cuento principal, la niña se empeña en enseñarlos a todos sus parientes a firmar. Empieza su empresa alfabetizante con su propio abuelo de 70 años, Valencia Pushaina. Con humor y un lenguaje poético, la narradora describe las dificultades que enfrentaba durante estas "clases" de escritura: "Mis pequeñas manos trataban de llevar las manos grades, callosas y arrugadas de mi abuelo por el sendero de las letras cursivas, pero al ver lo tenaz que sería mi empresa, decidí mejor enseñarle a firmar en letra de "palito"” (411-412). En este fragmento se nota una intersección de dos mundos; las manos pequeñas de la niña, diestras y capaces con los utensilios de escritura, contrastan con las manos callosas de su abuelo, marcadas (se supone) por años de trabajo. Se percibe una incongruencia similar entre las dos generaciones - la niña y el abuelo — en cuanto a su nivel de propensión al cambio. El

\footnotetext{
${ }^{41}$ A lo largo de este trabajo, he optado por citar el cuento "Manifiesta no saber firmar. Nacido: el 31 de diciembre" como aparece en la antología El sol babea jugo de piña, compilado por Miguel Rocha Vivas, por la facilidad de encontrar y poder consultarlo. La antología completa está disponible en la biblioteca virtual del Ministerio de Cultura colombiana.
} 
abuelo no se siente motivado a practicar esta nueva habilidad, y aunque se "dejaba llevar [durante las lecciones de la niña,] al poco tiempo se dormía" (412). Sin duda, la imagen de una niña impartiendo clases de escritura a su abuelo mientras éste duerme resulta bastante graciosa para los lectores. Otra vez, a través del humor, la narrativa de Simanca Pushaina logra agradar a sus lectores mientras los interpela a enfrentar algunos aspectos desagradables de la realidad Wayuu, tales como el analfabetismo, la pobreza y la desesperación.

Mientras que la niña tanto anhela ver que su abuelo firme algo (sobre todo, enfrente de los "cachacos" de la ciudad), para el viejo no le interesa hasta tal grado, explicándole a su nieta que "ya estaba muy viejo para hablar con el papel (escribir) y tampoco el papel quería hablar con él (leer)" (412). La niña aquí, imagen simbólica de la esperanza y la creencia en el cambio a través de la alfabetización, trata de imponer sus propios deseos a su abuelo. Sin embargo, es notable que ella tampoco critique a su abuelo por no querer aprender; la niña parece reconocer el derecho de su abuelo de mantenerse tal como es, firme en sus propias creencias y capacidades. Este hecho demuestra, en contraste con el comportamiento de los funcionarios del Estado, el nivel de respeto mutuo que se requiere tanto entre las generaciones como entre distintas culturas. Entonces, mientras que el relato demuestra el "irrespeto, el atropello y la explotación de que son objeto los indígenas Wayuu por parte de los políticos de turno" (Patiño Mejía, Reseña 393-94), también enseña una alternativa, siendo la niña el modelo de un comportamiento más digno. También cabe apreciar que, específicamente en esta primera sección del relato, la narradora se asegure de indicar correctamente la información biográfica que corresponde a cada miembro de su familia que menciona: "mi abuelo Valencia Pushaina 
(Colenshi) de la región de Paradero (Media Guajira)” (411) y “mi tío Ramón (Paraíso, Resguardo Caicemapa, Baja Guajira)" (412). Tal hecho demuestra otra manera de denunciar o invertir, dentro del propio cuento, la práctica de los funcionarios que quieren borrar o ignorar la identidad de los Wayuu al cambiarles el nombre en la cédula "oficial" de identidad.

El cuento se inicia con la indicación de que esta historia forma parte de una sucesión de eventos idénticos que la niña, a pesar de su edad, logra reconocer como un círculo vicioso. Las primeras tres secciones del cuento, que en total se divide en cinco partes, empiezan con la misma oración: “Aquel mes de octubre fue como los octubres anteriores que llegaron ellos a nuestra ranchería" $(412,414,416)$. Se repite esta frase para destacar la naturaleza cíclica de estos eventos; el hecho de que esta misma historia se repite revela una fuerte crítica, tanto hacia los políticos malintencionados como a los Wayuu por dejarse engañar, una y otra vez, con los mismos embustes. En general, la narrativa de Simanca Pushaina suele aprovechar del humor ligero de los personajes infantiles, aparentemente desenfadados, a la vez que impone una crítica directa y punzante. Por ejemplo, la segunda vez que llegan los políticos, la niña observa que "esa vez llevaron unos papeles grandotes que tenían la imagen de ese hombre que se llamaba 'Candidato"” (415). Los lectores seguramente encontrarán la gracia en el error de la niña, quien cree que el señor se llama "Candidato". Al mismo tiempo, no obstante, este pequeño detalle demuestra una ironía muy aguda. Al confundir el nombre real del candidato con lo que aparece en los papeles "grandotes", la narradora también juega con el rebautizo, invirtiendo la misma injusticia que es precisamente el tema central del cuento. Coleima así consigue el mismo derecho que suponen poseer los funcionarios 
automáticamente sobre los Wayuu, como si hubiera alguna ley natural que les asigne esta máxima autoridad.

En el mismo relato, Simanca Pushaina revela varios otros ejemplos de conflictos e injusticias que surgen a raíz de la intersección de dos culturas. Por ejemplo, a través del personaje tío Tanko, el cuento describe el círculo interminable de promesas, engaños, regalos y decepciones, impulsado por los políticos de turno y alimentado por los Wayuu con su renovación de esperanza con cada nueva proposición:

El puente que hicieron, hace ya un verano y un invierno, ¡se cayó y no lo han levantado! [...] tampoco han traído el molino para sacar agua y preparar nuestros elementos [...] Y la escuelita, la escuelita que prometieron para la comunidad y para que nuestros niños estudiaran, tampoco lo han hecho. (413)

La niña Coleima es capaz de entender y reconocer esta repetición de las mismas promesas y decepciones. Los políticos mantiene que "esta vez" va a ser diferente porque "el que estaba de candidato no era el papá sino el hijo" (413). Es tan abierta y repetitiva la crítica que, a pesar de la frecuente inclusión del humor e ironía, resulta imposible que los lectores no capten la esencia de la denuncia. La narradora parece entender que esta gente siempre engaña con las mismas palabras y los mismos regalos, pero ella también termina algo hechizada por la atención afectuosa que le brida uno de estos candidatos:

[...] ese señor Candidato, el mismo que me dijo 'princesita', mientras me daba un beso cerca de la boca y que prometió casarse conmigo cuando yo creciera, fue el mismo que se negó a ayudarnos cuando Toushi se enfermó y el mismo que dijo cuándo nos alejábamos de él: '¡esos indios si joden!' [...] Recuerdo que ese beso me robó el sueño por muchas lunas [...] Quería que el señor Candidato regresara y me besara nuevamente, pero no lo hizo. (416)

Este detalle parece señalar que es fácil dejarse engañar, pero aun así la solución no puede ser seguir repitiendo las mismas acciones que llevan a este engaño una y otra vez más. 
El cuento "Manifiesta no saber firmar. Nacido: 31 de diciembre" no es la primera noticia que tenemos de la supuesta "dificultad" de cedular a o gestionar un censo sobre los Wayuu. En 1936 el padre capuchino, José Agustín de Barranquilla, escribió su obra Así es la Guajira, cuyo título en sí demuestra un nivel asombroso de su autoridad autoasignado. Este libro revela varias características de la zona, tanto las geográficas y ambientales como su "elemento humano". Según el autor, es complicado bautizar a los Wayuu por no poder distinguir bien las identidades de los individuos:

Tenían que llevar sumo cuidado para no bautizar a un mismo indio varias veces, precisamente por las razones dichas ya, de la facilidad de movilizarse el nativo, a grandes distancias, y de no poder identificar con facilidad el personal, por ir todos con el mismo uniforme: el taparrabo, o la manta... Esta misma razón milita en las tareas de hacer el censo. Es claro que si se recurriera a las señales dactilógrafas, para hacer el censo, que la seña digital no engaña $[\ldots] .(57)$

Con estas observaciones escritas por el padre Agustín, se puede confirmar que desde hace un tiempo los intentos de organizar o identificar a los indígenas ha resultado complicado y hasta frustrante para los alijuna. Es más, se puede conjeturar que esta historia (de un enfrentamiento entre culturas) ha ocurrido, en múltiples maneras y con diversas encarnaciones, desde la época colonial. El cuento de Simanca Pushaina, entonces, es una forma de denunciar abiertamente una práctica deshumanizante que ha sucedido continuamente a través de los últimos 500 años.

La manera en que Simanca Pushaina deja testimonio de una injusticia, a través de la literatura, es similar a lo que han hecho otros escritores indígenas con el formato del testimonio escrito. El relato "Manifiesta no saber firmar. Nacido: 31 de diciembre" es similar al testimonio en que busca, con el mismo sentido de urgencia, hacer visible un problema de una comunidad que suele ser desdeñada por el estado hegemónico. Aunque 
el silencio femenino ha sido utilizado eficazmente en algunos momentos históricos, sobre todo con las escritoras coloniales, la persistencia de los problemas sociales apremiantes y las condiciones actuales en las sociedades indígenas no dejan que el silencio siga siendo una opción viable. ${ }^{42}$ Frecuentemente estas nuevas voces indignadas encuentran su mejor expresión en el testimonio, formato preferido por mujeres activistas como la argentina Alicia Partnoy, la nicaragüense Gioconda Belli, y la indígena guatemalteca Rigoberta Menchú, cuya obra Me llamo Rigoberta Menchú y así me nació la conciencia es factiblemente el testimonio más conocido.

John Beverly, crítico literario y cultural que se especializa en los estudios sobre la subalternidad, describe el testimonio en su ensayo "The Margin at the Center": "La situación de la narración en el testimonio tiene que implicar una urgencia para comunicarse, un problema de la represión, la pobreza, la subalternidad, el encarcelamiento o la lucha por la supervivencia" (26). ${ }^{43}$ Basándose en esta definición del testimonio, bien se puede aplicar el término a la narrativa de Simanca Pushaina. Su cuento demuestra problemas de represión, subalternidad, y una lucha por la supervivencia de las propias identidades de los Wayuu. Además, el texto escrito "Manifiesta no saber firmar: Nacido el 31 de diciembre”, junto con el blog de la autora, sus actividades activistas, y el documental basado en el cuento, indica una clara urgencia de comunicar dicho conflicto. ${ }^{44}$ La autora misma confirma: "Mis intenciones siempre serán dejar testimonios de todo lo que veo. Memoria utilizando el lenguaje para conservar el pasado"

\footnotetext{
${ }^{42}$ Guerra Cunningham nota que "el silencio y los espacios en blanco [son] como una estrategia textual que soterradamente transgrede el sistema impuesto por las construcciones ideológicas del falologocentrismo" ("Las sombras de la escritura" 145).

${ }^{43}$ Traducción mía.

${ }^{44}$ El documental fue dirigido por Priscila Padilla. Aunque resulta difícil conseguir una copia fuera de Colombia, vea el artículo de El Espectador, "Las cédulas de la burla wayuu”, para más detalles.
} 
(entrevista personal). Es más, no se debe olvidar que un testimonio también refiere a un documento legal, algo con lo cual Simanca Pushaina, abogada, también debería ser familiarizada. Con este texto, que se categoriza como un cuento pero a la vez podría ser un ensayo o folleto informativo, Simanca Pushaina ofrece una nueva visión para una escritura politizada de activismo indígena.

Aunque el otro cuento de Simanca Pushaina que se analiza en este trabajo, "El encierro de una pequeña doncella”, tiene como tema principal el encierro, rito de paso Wayuu, contiene asimismo varias muestras explícitas de crítica. Por ejemplo, cuando la joven encerrada se pregunta si volverá a la escuela cuando por fin sale del encierro, las memorias que este comentario evoca no son de ninguna manera positivas. Iwa-Kashy, el personaje principal, recuerda que "mi hermana [...] fue asaltada por otras internas que le arrancaron de un zarpazo la cadenita con la llave de nuestro baúl y fue retenida en el baño mientras las otras lo saqueaban" (6). ${ }^{45}$ Este pasaje perturbador es reminiscente de los asaltos, encarcelamientos y saqueos a que los indígenas fueron sometidos en la época colonial a causa de la insaciable codicia de los conquistadores y cuyas secuelas se perciben hasta hoy en día. Sin embargo, el caso detallado en el cuento de Simanca Pushaina no está tan claro en este sentido, y se puede suponer, dadas las tendencias de los internados en la Guajira actualmente, que los saqueadores en cuestión también son indígenas. El texto confirma tal sospecha:

Ahí no se sabía quiénes eran las que tomaban las cosas, lo que se sabía era que había muchos niños que eran enviados a los internados porque en sus rancherías no había nada que comer, y sólo llegaban al internado con lo que tenía puesto. Sé que en Nazareth también hay otro internado indigena, al cual llegan las madres y le ruegan a los misioneros

\footnotetext{
${ }^{45}$ La letra cursiva en esta edición del cuento (de la editorial Comfamiliar del Atlántico) representa los pensamientos de la narradora y sirven para distinguir de la voz del narrador omnisciente.
} 
capuchinos que se queden con sus niños, -porque en la ranchería no hay comida, no hay agua en el jagüey, las cabras no dan leche y allá sólo morirán de hambre. $(6)^{46}$

Este comentario, que casi parece un desvío de la historia central, revela abiertamente las condiciones pésimas que sufre mucha gente Wayuu. Hay que reiterar aquí que este cuento en particular, como se exploró detalladamente en el capítulo 2 de este trabajo, ha sido clasificado como literatura infantil. Así el lector, que se supone ser niño, ya no lee un cuento de "fantasía" como el prólogo del libro quiere indicar, sino más bien una representación vívida de la realidad ardua e inaguantable de muchos niños Wayuu. Por lo tanto, inclusive en un texto cuyo propósito principal no es necesariamente criticar o denunciar, todavía se perciben muchas señales y comentarios acerca de los abusos y las malas condiciones a los cuales los indígenas Wayuu actualmente se ven sometidos.

De igual modo, en los relatos de Siosi Pino se percibe una crítica explícita que puede interpretarse como una denuncia abierta y directa. En el cuento "Esa horrible costumbre de alejarme de ti”, Siosi Pino describe la angustia y exasperación que empujan a que unas madres busquen una familia alijuna que "eduque" a sus hijos, eufemismo que quiere decir abandonarlos para que trabajen como sirvientes en casas de los ricos. Similar al desespero que se nota en el fragmento arriba citado de Simanca Pushaina_-"llegan las madres y le ruegan a los misioneros capuchinos que se queden con sus niños" (6) - este cuento célebre de Siosi Pino pinta una escena análoga. El relato describe la experiencia de una niña de 7 años que va a Riohacha para trabajar en la casa de una familia adinerada. La niña no entiende por qué la han dejado allí y sigue esperando a que vengan por ella: "Los días aquí no me gustan. [...] 'Indiecita', me llaman, sin saber que soy

${ }^{46}$ Nazareth es un pueblo indígena en la Alta Guajira, cerca de Uribia. 
princesa y mi papá el cacique de la ranchería" (Dulce corazón 51). Cuando la niña rompe un jarrón en un intento de recuperar sus collares preciosos de la abuela que llevaba el día que llegó a la casa grande, es castigada severamente y recibe la primera paliza de su vida. Como si este escarmiento no fuera suficiente, unos días después llega su madre para recompensarle el jarrón destrozado: "Vi como mamá le entregaba un chinchorro, tres mochilas y un collar de coral" (53). La niña intenta en varias ocasiones escaparse, pero cada vez su madre tiene que devolverla a la casa de su "madrina" explicándole que "es por tu bienestar, te educarán y podrás ser otra persona con buenas costumbres. Agradecida le estaré [a la madrina] toda la vida" (58). La madre Wayuu no puede imaginar otra opción para su hija, mientras que la niña, arrancada obligatoriamente de su gente, no es capaz de entender las consecuencias de este destino.

A diferencia de la niña Coleima del cuento de Simanca Pushaina, la narradora de este relato no parece tener las mismas capacidades extraordinarias de percepción y análisis. En este caso, sin embargo, la niña sí termina asistiendo al colegio y, eventualmente, acostumbrándose a la vida de servidumbre. En la conclusión del cuento, se observa que lo que empezó como un alejamiento forzoso termina siendo la única realidad que conoce. Este cuento de Siosi Pino demuestra hasta qué medidas de sacrificio les toca a las familias Wayuu. Aunque el texto nunca parece indicar que la madre no quiere a su hija, se percibe claramente el dolor y las circunstancias desesperantes que la llevan a abandonar a su hija. Ocho años después de llegar a la casa de la madrina, la joven da una fiesta para celebrar la Navidad y, cuando la sorprende su propia madre al llegar a la casa, la joven ni intenta disimular su repulsión: "Estaba curtida y arrugada por el sol. Me abrazó y sentí su olor a humo. Me separaré rápidamente pensando que podría 
ensuciarme el vestido de la fiesta. La metí a la casa por el portón del patio, para que no la vieran, pues había invitados en la sala" (59). Es más, cuando la niña se ha crecido, ya no pertenece ni a un mundo ni al otro. Se siente un desafecto a su propia cultura y raza, mientras que en la ciudad, tampoco la acepta: "Los rasgos de la tribu me delatan. En cualquier fiesta soy la indiecita. Tengo confusión de sentimientos. Creo mía esta casa ajena y de mi Guajira indomable ni recuerdos tengo ya" (61). Con este relato desgarrador, Siosi Pino revela unos de los múltiples efectos irreversibles de una existencia marcada por una pobreza extrema. ${ }^{47}$ Con este cuento de Siosi Pino, se puede apreciar su forma innovadora de presentar una denuncia directa - en este caso en contra de las condiciones desesperantes que conducen a que muchas familias abandonen a sus hijos - y, a pesar de revelarse a través de un cuento corto, narrado por una niña, se siente la potencia de su mensaje crítico.

El relato "El dulce corazón de los piel cobriza", por ejemplo, describe la aventura de tres niños alijuna que, picados por la curiosidad, deciden seguir a su compañero de clase Wachir a su pueblo Wayuu. Después de experimentar por su propia cuenta el misterio y generosidad de la comunidad indígena, los tres compañeros alijuna deciden quedarse en la ranchería durante las vacaciones, fingiendo haber recibido permisos de sus padres. Mientras tanto, en Riohacha los padres preocupados informan a la policía y ofrecen recompensar a quien les informe de su paradero. Después de siete meses de

\footnotetext{
${ }^{47}$ La pobreza y la desnutrición son asuntos muy apremiantes hoy en día en la Guajira. En febrero de 2016, El Espectador publicó un artículo que revela unas estadísticas inquietantes: "En 2015 van 808 niños muertos por inanición y desnutrición, según comisión del Senado". Según un informe publicado por el $\mathrm{BBC}$, estos últimos coincide con la peor sequía en 30 años ("Colombia's Alta Guajira region struggles with drought" s.p.). Mientras que algunos atribuyen esta deficiencia de agua al fenómeno meteorológico El niño, otros culpan a las actividades mineras de la región y la represa El Cercado que desvía el río Ranchería (vea el Apéndice B para la carta de Siosi Pino al presidente Santos relacionada a este proyecto).
} 
ausencia, se emprende un batallón de rescate que "deja en evidencia la imagen popular de los wayuu como abductores salvajes" (Rocha Vivas, Textualidades 262). Cuando por fin los hallan entre los Wayuu, "la versión de los pequeños de su huida voluntaria no [es] tomada en cuenta" (Siosi Pino, Dulce corazón 46). En este cuento se revelan múltiples ejemplos de una crítica directa y severa. En una ocasión, por ejemplo, el narrador omnisciente describe el maltrato físico de un policía hacia el cacique Irrua, que va a la ciudad para buscarle una medicina a su madre. Se tropieza accidentalmente y cae sobre un agente de la policía quien, furioso, le "apuntó con un revólver y lo hizo recostar contra la pared. A gritos le pidió un documento de identidad" (32). El cacique, que no entiende el castellano, le contesta en Wayuunaiki: "Kapurain putuma maunapuui taya-que significa respétame soy palabrero" (33). Tras otros episodios que revelan más falta de respeto y una imposibilidad de comunicarse, la policía le vacía la mochilita y le quita "abusivamente" el dinero que tenía para comprar el medicamento.

El informe "oficial" de la policía declara que "un indocumentado había agredido verbalmente a un agente" (33). Como castigo, la policía lo encarcelan dos días, "durante los cuales debía lavar los baños del cuartel. Como realizaba con cierta torpeza el aseo los guardias lo burlaban y algunas hasta le golpearon las nalgas descubiertas mientras se agachaba para limpiar los inodoros" (33). Estas muestras de humillación hacia el cacique Wayuu, más aún a un palabrero, indican qué tan profundas y arraigadas son las percepciones de superioridad que conservan algunos funcionarios del Estado. El caso entre la policía y el cacique exhibe un brusco choque de culturas en el cual no existe ni el esfuerzo mínimo de entenderse, por lo menos por parte de la policía. El cacique, lejos de su comunidad, pierde todo indicio de autoridad. Es más, la madre del cacique, por no 
recibir el tratamiento necesario, pierde la visión, así revelando simbólicamente algunas de las secuelas dañinas e irreversibles que puedan resultar de esta clase de abuso.

Al final del cuento, cuando se logra "rescatar" a los tres niños alijuna, la sociedad entera es tan encolerizada que una resolución pacífica entre los Wayuu y los alijuna ya no parece posible: "Se arraigó tal animadversión en los riohacheros que en el mercado humillaban y trataban en forma déspota a los wayuu y en los hospitales los atendían de último [...]. Algunos estudiantes, sin motivo, maltrataron a un joven indígena, le rompieron dos costillas y un diente" (46). Sin embargo, los tres niños desaparecidos, el motivo de todo el alboroto, nunca pierden su alta consideración hacia los Wayuu. Al contrario, terminan con aún más estima para sus vecinos Wayuu: “Allí [en el borde de la ciudad y el desierto] los tres agarrados de las manos, con un súbito estremecimiento en el cuerpo pidieron a Dios cuidara a los wayuu y juraron que cuando fuesen adultos visitarían a sus amigos de piel cobriza para expresarles su respeto" (46-47). Es notable que los personajes infantiles en esta historia, Wayuu y los tres niños alijuna, sean los únicos que se comportan de una manera razonable, mientras que los adultos (alijuna) demuestran una incapacidad para la tolerancia y una falta de interés en conciliarse con los Wayuu. Esta inversión de intelecto es un truco narrativo que ambas autoras implementan ingeniosamente para demonstrar su resistencia a la infantilización del indígena. Al indicar la posibilidad de ambos grupos de entenderse, como en el caso de los Wayuu y los tres niños en el "El dulce corazón de los piel cobriza", Siosi Pino revela un mensaje esperanzador para una realidad intercultural futura.

Mientras que Siosi Pino demuestra, a través de sus cuentos, sus aspiraciones futuras para una nueva realidad social entre las dos culturas que habitan la Guajira, 
también nos recuerda de unos asuntos apremiantes que afectan gravemente a los Wayuu en la actualidad. En la carta que escribió al presidente Juan Manuel Santos (vea el apéndice B), se observa otro tipo de crítica directa expresada por Siosi Pino. Esta carta, publicada en el periódico El Espectador de Bogotá en abril de 2012, expresa de un intento de comunicarse con el presidente para pedir que intervenga en detener un proyecto de Cerrejón, una compañía multinacional de carbón, que había propuesto desviar el río Ranchería con el propósito de extraer aún más carbón. Aquí Siosi Pino capta con sus imágenes poéticas, primero apaciguándole a su lector antes de presentarle su protesta y súplica. Primero, dibuja el escenario de un mundo sencillo pero pacífico:

Las gentes por aquí viven de la pesca. Aún los niños capturan lizas, bagres, bocachicos y camarones que son nuestro alimento. Las mujeres recogen cerezas, iguarayas, mamoncillos cotoprix, coas silvestres para venderlas $[\ldots]$ El Ranchería es el único río de los wayuu. La única corriente de agua que atraviesa este territorio ancestral. Al río vamos a bañarnos. Es una diversión exultante. Allí, los jóvenes se enamoran y fundan lazos de amistad. Las mamas lavan ropa y los pequeñitos aprenden a nadar. Con el barro blando de las orillas las niñas fabrican muñecas, tacitas y platicos que secan al sol. (2)

Y luego, sin advertir al lector, Siosi Pino nos hace entrar en otro ambiente completamente distinto con un estilo más formal y académico, hasta científico. Pronto se da cuenta de que el modo de vivir de los indígenas o la manera en que se expresan no significan ninguna falta intelectual ni una escasez de conocimiento acerca de la realidad ambiental que permea en la actualidad:

En un libro del Cerrejón titulado: 'Resumen del proyecto de expansión para grupos de interés', en su página 60 , dice que el cambio climático global (CCG) nos afectaría: 'El clima en la Guajira podría tornarse más cálido y seco, con una disminución en la pluviometría de 5 a $10 \%$. Los glaciales de la sierra nevada de Santa Marta podrían desaparecer hacia el año 2050, lo que afectaría la disponibilidad de fuentes de agua en la región'. ¿Cómo será la vida del wayuu sin el río Ranchería? (2) 
Aquí la autora demuestra su conocimiento acerca de los sucesos de corrupción, los tratos ocultos, y los proyectos lucrativos que le rodean. Con su carta, Siosi Pino revela que ha estudiado minuciosamente el tema, hecho evidenciado por las numerosas referencias citadas. Además, la autora expone claramente el mensaje que no va a permitir que sigan engañando a los Wayuu con las mismas palabras y mentiras. Critica la corrupción de las compañías mineras que frecuentemente tratan de tergiversar los datos para conseguir el "permiso" de las comunidades afectadas. La carta de Siosi Pino al presidente Santos ejemplifica una innovadora técnica de la escritora Wayuu, una estrategia también reflejada en los escritos de Simanca Pushaina. Similar a los palabreros Wayuu, demuestran una capacidad excepcional de manipular y controlar el poder de las palabras.

\subsection{Cuestionamiento de los valores de la cultura dominante}

A quién llaman analfabetas

a los que no saben leer

los libros o la naturaleza;

unos y otros

algo y mucho saben; durante el día

a mi abuelo le entregaron un libro

le dijeron que no sabía nada;

por las noches

se sentaba junto al fogón

en sus manos

giraba una hoja de coca

y sus labios iban diciendo

lo que en ella miraba.

- Hugo Jamioy Juagibioy, camëntsát

\footnotetext{
${ }^{48}$ Hugo Jamioy Juagibioy es oralitor (vehículo de la expresión oral de su cultura) e investigador camëntsá de la valle de Sibundoy en el Departamento de Putumayo; su padre es Alberto Juajibioy Chindoy, uno de los escritores indígenas pioneros en Colombia, y su madre, Ati, pertenece a la comunidad arhuaca/bintukua en la Sierra Nevada de Santa Marta (Rocha Vivas Pütchi vol. 2 63). Esta unión intercultural entre dos distintos pueblos indígenas ofrece a Jamioy Juagibioy una perspectiva única que transciende las líneas de separación y aislamiento entre las diversas comunidades indígenas del país.
} 
En los cuentos indígenas colombianos, los escritores frecuentemente intercalan temas que cuestionan las perspectivas y nociones de la cultura hegemónica. En varias obras, por ejemplo, aparecen temas de preservación lingüística que reclaman la protección y valorización de cualquier de los 66 lenguas nativas que sobreviven actualmente en Colombia. En muchos escritos, se cuestiona el término analfabeto al defender su lengua nativa u otras maneras de "leer", "saber", y "entender". En las obras de Siosi Pino y Simanca Pushaina, a pesar de ser escritas en castellano, siempre se entrelazan muchos términos en Wayuunaiki con la prosa en castellano. El tema del lenguaje, sin embargo, y específicamente los conflictos que surgen a raíz de una falta de comprensión comunicativa, es uno de los principales que se tratan en los textos Wayuu.

Por ejemplo, en "Esa horrible costumbre de alejarme de ti", describe la niña que ella "trabajaba y era el hazmerreír de las mandonas, pues como poco sabía castellano, cada palabra mal pronunciada (y eran todas), las desternillaba de la risa” (57). En "Manifiesta no saber firmar. Nacido: 31 de diciembre" la madrina explica de una manera incuestionable que "no es ay que es 'yuca', que no es wat-tachón que es 'mañana', que no es arika que es «tarde», que no es aipá que es 'noche'” (414). Aquí la madrina revela una actitud maniquea que hay lo correcto (castellano) y lo incorrecto (Wayuunaiki), creando una clara bifurcación entre los dos grupos y negando la posibilidad de unirse. A pesar de tantos ejemplos de la irrisión que sufren los Wayuu por no hablar bien el castellano, ambas autoras ofrecen a sus lectores alijuna un glosario, demostrando un deseo de compartir el conocimiento entre culturas. Así los lectores aprenden que "Wairriña" son los zapatos tejidos, que "Wopu" quiere decir camino, y que "Kay" representa el sol, para dar unos ejemplos (Dulce corazón 121-123). Estos pequeños 
diccionarios Wayuunaiki-español no solamente ayudan al lector a interpretar el texto, sino también su inclusión reafirma la función didáctica de las obras de ambas escritoras.

En los textos de Siosi Pino y Simanca Pushaina, se percibe un cuestionamiento de los valores de la sociedad alijuna y desafían la certeza absoluta de ciertos conceptos como el alfabetismo, la educación, la riqueza y otros sistemas de valor. El cuento de Siosi Pino, "El dulce corazón de los piel cobriza", describe a los tres niños alijuna y su interés en conocer las costumbres del pueblo Wayuu, entre ellos las normas ancestrales y la lengua Wayuunaiki. Dice el cacique Irrua, después de aceptarlos a su comunidad, "Es sabio aprender de los wayuu. Los arijuna aunque son muchos ignoran cosas simples como la hospitalidad y aun cuestiones profundas como el honor y la verdad" (34). En este relato, los tres niños alijuna rechazan las lecciones de la cultura hegemónica en preferencia por los valores revelados durante su estancia en la comunidad Wayuu. Durante su tiempo con los Wayuu los indígenas les imparten clases informales en materias tales como la medicina natural, la caza y la pesca, la mitología Wayuu, la música ancestral, el baile yonna, y el proceso del encierro, entre otros rituales. Cuando llega a la ranchería el cacique Irrua, padre de Wachir, aprueba que su hijo siga estudiando y valore su habilidad de leer y escribir: "Wachir le mostró [al cacique] que sabía escribir tranzando largas frases en un papel, le leyó la cartilla de la escuela y le expuso los dibujos realizados en clase. El cacique orgulloso accedió para que continuara los estudios" (31). Wachir explica a sus tres compañeros alijuna que heredó estas habilidades con la lectura y escritura de su padre, cacique admirado y palabrero que "con diplomacia soluciona conflictos entre clanes" (31). Apenas llegados los tres compañeros alijuna a la ranchería de Wachir, se enteran de una fiesta que habían anunciado en una ranchería vecina para 
celebrar la graduación de una médica Wayuu. Conjuntamente con las celebraciones de este evento que honra el rol de la medicina tradicional, se revela una valorización paralela hacia la ciencia Wayuu: "En ese rancho aparte una médica experimentada enseña a la graduada los ritos y secretos botánicos” (25). Además de demostrar el valor de la educación alijuna que recibe Wachir en el colegio de la cuidad, el cuento también revela que ese sistema educativo no figura la única manera de instruirse, y tampoco es superior a las enseñanzas ancestrales de los Wayuu.

En su artículo "Wayuunaiki: Lengua, sociedad y contacto”, Pérez van-Leenden explica que "la educación tradicional [de los Wayuu] es una educación en la vida y para la vida, es un modelo que mantiene al individuo en un discurso profundamente práctico" (189). El concepto de la educación se manifiesta en diversas formas en los cuentos de Simanca Pushaina y Siosi Pino, y en ambos casos se destaca la posibilidad de encontrar en la cultura Wayuu alternativas educativas que son igualmente plausibles y valiosos. En "El encierro de una pequeña doncella", Iwa-Kashy, al encontrarse encerrada y aislada, sólo piensa en sus estudios y si podrá regresar después de terminar con el rito de paso: "Para este tiempo aún no conozco los motivos que me llevaron a este encierro, lo único que me da vueltas en la cabeza, como el sonido de la campana en el internado, es si volveré a estudiar" (5). Una lectura inicial de esta sección tal vez llevaría a la conclusión que Iwa sí desea volver a estudiar, pero la historia que la narradora cuenta justo después de esta declaración sugiere otra realidad posible. Al principio destaca la alegría de emprender todos los preparativos para partir al internado en Uribia: "Recuerdo que mamá nos compraba, a Jayarra mi hermana menor y a mí, jabón chino, [...] champú de romero 
para nuestros cabellos negros, y telas de algodón para nuestras mantas. Nuestro baúl de madera se llenaba con las nuevas cosas y se hacía necesario arrastrarlo por su peso" (5-6). Luego, comparte otras memorias: la del saqueo de su baúl por las otras internas y un triste comentario sobre la realidad económica de la mayoría de sus compañeras que no gozaban de tanta prosperidad como su familia. Se entera de que, a pesar de la relativa fortuna de Iwa, la situación para la mayoría de sus compañeras es grave e desesperante.

Además, durante el encierro, Iwa reconoce que todo lo que está experimentando, las enseñanzas de las mujeres mayores y las visitas nocturnales de la araña tejedora Waleket, conforma parejamente una forma alternativa de educación: "Nunca le revelaría a sus institutrices y a su madre sobre sus clases secretas de tejido" (10). Este hecho señala un aspecto fundamental de los escritos indígenas, en que piden una revalorización de los conceptos de la inteligencia, educación, sabiduría, y el alfabetismo, rechazando la definición maniquea impuesta por las sociedades dominantes. Al destacar unas alternativas a dichos conceptos, además de honrar las ciencias y enseñanzas ancestrales, las escritoras Wayuu revelan una forma de protestar las condiciones sociales a las cuales su pueblo se ve sometido. Sus cuentos desafían a los lectores a reevaluar sus propias suposiciones y juicios, ofreciéndoles otras percepciones y definiciones de lo que significan la inteligencia, educación o incluso el concepto de alfabetismo.

El relato de Estercilia Simanca Pushaina, "Manifiesta no saber firmar. Nacido: 31 de diciembre", por ejemplo, pone en cuestión la necesidad de alfabetizar al abuelo. Mientras que la niña considera que la escritura representa una posibilidad de mejorar las condiciones de los Wayuu, nunca duda de la inteligencia de sus parientes que no habían tenido la necesidad o quizás la oportunidad de aprender. Es más, se revela que el abuelo 
de la narradora define la escritura y la lectura de una forma distinta, subrayando la importancia de la oralidad en el pueblo Wayuu: “[el abuelo] me dijo que él ya estaba muy viejo para hablar con el papel (escribir) y tampoco el papel quería hablar con él (leer)" (412). No obstante, la niña narradora entiende la importancia de las habilidades de leer y escribir en alijunaiki (castellano) para no dejar que los alijuna sigan engañándolos y para arrancar una vez para siempre la etiqueta hiriente de que los Wayuu manifiestan "no saber firmar". Con esta frase tan definitiva, la sociedad hegemónica quiere separar los que "saben" de los que "no saben". Tales divisiones representan una laguna formada por siglos de malentendidos y falta de compresión mutua entre las poblaciones indígenas y los otros, primero los colonizadores y luego el Estado. Los de la cultura dominante, por no querer reconocer las múltiples maneras igualmente viables de ver al mundo e interpretarlo, continúan insistiendo en que la división entre ellos mismos y el otro es una separación natural y justa.

Los cuentos de Siosi Pino y Simanca Pushaina asimismo ponen en cuestión los conceptos de la riqueza y otros sistemas de valor que mantienen los no Wayuu. Por ejemplo, el nombre Wachir, el joven Wayuu del cuento "El dulce corazón de los piel cobriza", significa "el que es rico", una designación que seguramente no refiere a su estatus económico sino a sus capacidades intelectuales. Mientras que Wachir y su familia valoran las ceremonias Wayuu, no reconocen el significado de los ritos del colegio alijuna: "A fin de año [escolar, Wachir] obtuvo el premio como mejor estudiante, pero ni él ni su familia asistieron a los actos de clausura" (23). Las ceremonias oficiales, documentos, y certificados, tan valoradas en la cultura colombiana general, no poseen la misma importancia en los pueblos indígenas. Esta idea se ve reflejada claramente en el 
cuento "Manifiesta no saber firmar. Nacido: 31 de diciembre". Al principio del relato, en el cual la niña explica cómo intentó enseñarle a su abuelo a firmar su nombre, describe una situación que revela una confluencia de culturas absurda: "Fue por aquella época cuando llegaron unos cachacos a llevarle un diploma que lo acreditaba como un campesino colombiano, en el día nacional del campesino. Escuché que mi abuelo debía

firmar un recibo que constatara que él había recibido dicho diploma" (412). Se cuestiona aquí, a través del humor e ironía, la imposición de un sistema de valores por la parte del Estado colombiano que no corresponde al modo de pensar indígena.

\subsection{El levantamiento de los más pequeños}

En los cuentos de Simanca Pushaina y Siosi Pino, los niños suelen ser los más visionarios y sabios, lo que representa una inversión de poder (mayores-menores) y una crítica de los valores de los adultos. Es plausible ver, tomando de nuevo el tropo colonial del indio-como-niño, que los niños simbolizan a los indígenas mientras que los adultos encarnan el concepto del otro, que en estos cuentos podría ser el Estado colombiano, el alijuna, o el mundo occidental, según el caso. Como antes se mencionó, los escritos de ambas autoras Wayuu logran revolcar esta situación de opresión y manipulación, dando voz a los niños y transformándolos en los verdaderos héroes de sus cuentos. El ejemplo expuesto en el cuento "El dulce corazón de los piel cobriza" es una de las mejores afirmaciones de esta teoría. En este relato es evidente que los niños alijuna reconocen y respetan los valores que mantienen el pueblo Wayuu mientras que los adultos no se muestran capaces de manifestar esta misma actitud. El tendero, beneficiario de la recompensa por haber identificado a los tres compañeros alijuna con el amigo indígena, expresa rotundamente su aversión hacia los Wayuu: “[Los niños desaparecidos] estaban 
delgados, seguro que reciben mal trato. Estos indios negocian con venezolanos, tal vez piensen venderlos allá" (39). Hasta el alcalde confirma que "los indios no deben mezclarse con la gente" (39). Mientras tanto, los tres compañeros alijuna aprenden la lengua Wayuunaiki, participan en las fiestas y tradiciones culturales, y disfrutan del estilo de vida en la ranchería Wayuu. El cuento no deja en duda que los adultos actúan de una forma imprudente e ilógica; sus comentarios y reacciones exageradas señalan un profundo vilipendio que envenena la sociedad de los grandes.

Este mismo fenómeno del "niño-indígena sabio" aparece también en los cuentos de Estercilia Simanca Pushaina. En "Manifiesta no saber firmar. Nacido: 31 de diciembre", la narradora medita sobre ciertos fenómenos y realidades que la niña logra identificar mientas los adultos siguen dejándose traicionar: "No sé por qué tratan a esta gente como si fueran caciques. No se dará cuenta mi tío que siempre lo engañan con las mismas palabras y los mismos regalos" (413). Un cuento como "El encierro de una pequeña doncella" contiene más preguntas que respuestas, una particularidad de acuerdo con la curiosidad característica de los niños. Por ejemplo, la narradora joven del cuento, Iwa-Kashy, ${ }^{49}$ inquiere: “ ¿Cuánto durará este encierro [...]?” (1) y “¿Por qué me toca hacer esto [...]?" (5). Asimismo, el amigo de Iwa, Jimaay, expresa sus propias dudas: “¿Por qué la han encerrado [a Iwa] y apartado de nosotros?” (13) y “ ¿por qué no dejan que yo la vea?" (14). La autora Simanca Pushaina explica que prefiere usar niños como los personajes principales "porque son los únicos que pueden ofrecer preguntas inocentes para respuesta[s] obvias y que los adultos ya no percatamos. Porque si un niño o niña es el que hace la crítica es más reflexivo ya que todos mis textos llevan implícita una crítica

\footnotetext{
${ }^{49}$ Según el glosario que la autora incluye al final del cuento, Iwa-Kashy es un nombre compuesto que significa Luna de Primavera en Wayuunaiki. (17) En otras versiones o artículos se escribe Iwa-Kashí.
} 
al sistema y también a los usos y costumbres" (entrevista personal).

Se identifica esta creencia claramente demostrada en el relato "Manifiesta no saber firmar. Nacido: 31 de diciembre" en que la joven narradora plantea una serie de preguntas a lo largo del texto que cuestiona directamente los valores de los alijunas y su falta de interés, conocimiento y respecto hacia la cultura Wayuu. Cuando la narradora observa las interacciones entre los de su clan y los políticos de visita, se encoleriza por la actitud burlona y la falta de respecto de los funcionarios hacia los Wayuu. Parece que ella es la única capaz de ver que ellos "tomaban la chicha agria y hacían como si les gustara, pero al menor descuido de mi tío había gestos de desagrado en sus caras; otros las derramaban a propósito y fingían un accidente" (413). La pregunta fundamental de la narradora siempre revela un sistema de valores distinto a los alijuna: “¿Acaso no saben ellos que la chicha agria es la que le brindamos a quienes vienen a nuestra tierra, como muestra de nuestro respeto?" (413-414). La niña tampoco se deja engañar por la falsedad de sus palabras. A pesar de su supuesta inocencia, reconoce la incongruencia entre lo que dicen los alijuna (el nombre que dan) y lo que la realidad demuestra:

Y sus mujeres, sus mujeres vienen buscando niños para convertirlos en sus ahijados y así, según ellas, tener el deber cristiano de cuidarlos y educarlos. ¿Educarlos? A qué le llaman ellas educación si lo que hacen con nuestros niños es tenerles de sirvientes en sus casas de cemento; decirles que la comida no se toma con la mano, sino con la cuchara; que uno no debe andar por ahí con los pies descalzos como los indios, como si no lo fuéramos [...]. (414)

En este comentario, la niña revela un alto nivel de percepción que parece no corresponder a su edad. Aunque algunas de sus preguntas (¿Por qué? ¿Con qué derecho?) parecen demasiado sencillas, en realidad son las más perspicaces y esenciales. Tomar la perspectiva de una niña que observa estos engaños, la burla y el maltrato cíclicos, revela 
un intento de volver a lo fundamental e intentar remediar los conflictos como si fuéramos niños, todavía no marcados por el engaño repetitivo y las promesas no cumplidas.

Similar a la reconfiguración del tropo colonial del indígena como niño, encontramos en los cuentos de Simanca Pushaina y Siosi Pino otra crítica colonial que se basa en una inversión de la imagen del indígena como animal. En muchas instancias los personajes de sus escritos se comparan con animales o aparecen animales como personajes principales, una particularidad también abundante en los cuentos infantiles. Un notable ejemplo de la presencia de los animales se encuentra en el cuento de Vicenta Siosi Pino, "La señora Iguana”, relato en el cual una iguana convence a los seres humanos que ella también tiene derechos para vivir en la naturaleza de su jardín: "Quiero tener hijos para asolearlos y pasearlos por las lagunas aspirando el aroma de las cerezas después de las lluvias mientras escuchamos la música de los pájaros. Por favor no me mate" (Dulce corazón 93). Ana Patiño Mejía mantiene que este cuento también ofrece un mensaje sobre las oportunidades para un diálogo pacífico en remediar las relaciones interculturales: "De nuevo aquí, a partir de la intermediación de los niños, es posible una convivencia respetuosa y feliz entre seres de diverso origen, en este caso entre los animales del jardín y los humanos” (Las cuentistas 153). La señora Iguana expresa esta súplica a la dueña del jardín a través de una carta, otra vez destacando el rol de la palabra (escrita) en la búsqueda de la reconciliación.

En "El encierro de una pequeña doncella", Iwa-Kashy, una niña Wayuu, se describe en términos no humanos, en particular después de que le cortan todo el cabello, un componente simbólico del ritual del encierro: "-parezco un erizo- pensaba" (1), "tuve miedo de que mamá me volara una oreja, era como si estuviera cortándole la lana a un 
ovejo" y "Las vieja Yotchón no hace otra cosa que decirme - Jucheé puriku-oreja de burro" (2). El nativo idealizado, o el "nativo como un ser eminentemente natural" (Orrego Arismendi 122) es una imagen que aparece frecuentemente en los textos indianistas e indigenistas; se caracteriza por una fuerte conexión con el mundo natural, lo que muchas veces lleva a una fusión o asimilación con la animalidad. Rocha Vivas describe que "los relatos indígenas se las ingenian para hacer caer a los cazadores en sus tontas trampas $[\ldots]$ La cadena alimenticia se rompe gracias a sus ocurrencias, a sus trucos, a la capacidad de voltear las situaciones a su favor" (Palabras mayores 37). El truco de inversión entre el hombre-animal o grande-pequeño, es una estructura común a lo largo de la historia de expresión artística, un "motivo mitológico" en el que el pequeño sobresale. Igual que los personajes-niños, aquí las representaciones de los indígenas como animales son reconstruidas para utilizar como herramienta de resistencia. La niña Iwa-Kashy, quien al principio del cuento se compara con un erizo, cordero y burro, se convierte en una verdadera princesa moderna-madre Wayuu y además persona de influencia política en la comunidad. Una inversión del tropo colonial del indígena como "buen salvaje" simboliza una inversión de la estructura social y las posibilidades para repensar la inclusión de los valores indígenas en la sociedad general.

\subsection{Voltear el bautizo}

En varios cuentos de Simanca Pushaina y Siosi Pino se revelan diversas situaciones en las cuales se sustituyan los nombres por otros. Por un lado, cambiarle el nombre a alguien quiere decir robarle de su identidad y herencia. Sobre todo en la sociedad Wayuu, donde se señala el nombre del clan con el apellido, tomar este derecho de una persona es una forma de extirparla de su propia cultura. En el cuento "Manifiesta 
no saber firmar. Nacido: 31 de diciembre", la narradora revela un diálogo representativo de esta práctica de rebautizo:

[...] que tú no te llamas Tarra Pushaina sino 'Sara Ramírez'... -¿Ramírez? ¿Por qué?

-Porque eres mi ahijada.

$-i$ Y mi clan?

-¡Ay, no niña eso solo se usa en el monte! (414)

Por el contexto, el lector supone que esta conversación es una reproducción de una que posiblemente tuvo lugar entre una pariente suya (una joven Pushaina) con su "madrina". La narradora da por entendido que este reemplazo de nombre es algo que suele pasar cuando los jóvenes van a "educarse” en las casas de los alijunas. La práctica de quitarle los nombres - Tarra (el nombre dado) y Pushaina (de su clan) — demuestra una actitud de autoridad suprema por la parte la madrina. Además, su reacción que "eso solo se usa en el monte" revela un desprecio hacia el estilo de vida Wayuu (campo) y una valoración de superioridad a la cultura dominante (y hacia la ciudad, en contraste).

En el cuento, "Esa horrible costumbre de alejarme de ti", el lector nunca se entera del nombre real de la niña narradora. De todas formas, los demás le dan un nombre: "Indiecita". La narradora revela que, incluso cuando ha crecido y vive en la ciudad, en cualquier contexto sigue siendo la "Indiecita". Al final del cuento, la narradora ya no sabe quién es ni qué representa. No puede descansar por tener que dar tantas vueltas emocionales, yendo simbólicamente desde la ciudad al desierto sin encontrar su lugar, buscando desesperadamente pero nunca encontrando la esencia de su identidad. Las palabras de una señora enojada por fin le revela lo que es, su triste destino: "Hoy, una vecina, porque el perro ensució su terraza, me ha gritado las palabras que por años buscaba y no hallaba. ¡India desnaturalizá y desgraciá!” (61). Por razones infundadas, la 
vecina alijuna la conecta con la animalidad y la suciedad. De todas formas, sigue siendo una "India", ni siguiera "Indiecita" como en su niñez. Es más, la anonimidad que se presenta en este cuento demuestra otro nivel de desprecio, ya que la madrina Flor y los compañeros del colegio ni la reconocen como individuo. Es más, al no darle nombre a la narradora, Siosi Pino indica que ella es todos los indígenas a la vez que no es ninguno de ellos; su falta de individualidad le da a su historia un carácter representativo.

Se encuentra el ejemplo más explícito de esta práctica de "rebautizar" en el relato de Simanca Pushaina, "Manifiesta no saber firmar. Nacido: 31 de diciembre". Este cuento critica directamente la irrespectuosa costumbre de transformar los nombres de los individuos Wayuu en la Registraduría Nacional del Estado Civil del país. Para acumular más votos en las próximas elecciones, los políticos de turno buscan cedularlos a los indígenas rápidamente y en masa. Su desprecio hacia la población, que cree ignorante, resulta en un escenario de burla insolente y un borrado de su identidad y herencia. Atestigua la niña narradora:

Toda mi familia hizo una larga fila junto con otras gentes que venían de otras rancherías, para recibir una tarjetita plástica que ellos llamaban 'cédula'. Eran las mismas que ellos se habían llevado una semana antes de las 'elecciones'. Ese día me enteré que mi tío Tanko Pushaina se llamaba Tarzán Cotes, que Shankarit se llama Máximo, [...] que Cotiz se llamaba Alka- Selkser, Jierranta se llamaba Hilda, el primo Rafael Pushaina se llamaba Raspahierro, mi primo Matto se llamaba Bolsillo, y por un momento temí que conmigo pasaba lo mismo. (416-417)

Como explica Rocha Vivas, Colombia tiene una larga historia de rebautizar a través de los cambios de nombre y que "está marcada desde su nombre mismo por la colonización" (Textualidades 5). Especifica que Simanca Pushaina y sus personajes del cuento "Manifiesta no saber firmar. Nacido: 31 de diciembre" han "destapado 'tamaño 
problema': el de la colonización de nombres que inició con Colón mismo, en 1492, y en el Caribe" (Textualidades 11). La permutación ofensiva de nombres, como se percibe en el texto de Simanca Pushaina, es una antigua práctica colonial que sigue vigente hasta el día actual, reflejando la falta de respecto y el desprecio que todavía demuestra el Estado colombiano hacia las poblaciones indígenas.

No obstante, en el cuento de Siosi Pino, "El dulce corazón de los piel cobriza" se despliega una inversión de esta práctica humillante de rebautizar a través de los nombres. La narración empieza el primer día de clases de Wachir con la revelación de que "todos los niños estaban riéndose" (17), pero a Wachir no le importa, firme en su decisión de asistir a un colegio 15 kilómetros de su ranchería: "Había pedido a su papá lo dejara estudiar en la ciudad para que los arijuna no lo engañaran" (17). A pesar de las provocaciones y maltrato de los demás niños, quienes le acosan gritando "indio, indio, indio" (18), Wachir pronto se establece en la comunidad escolar con su lengua aguda y la presteza con que responde a las burlas. El niño Wayuu también participa en la práctica del rebautizo, dándoles a los niños con apodos socarrones, tales como "ojo de vaca" y "nariz de gorgojo":

A quien se le acercaba fue llamándolo por su defecto físico sobresaliente. A Teódulo le colocó Gallinazo Calvo por su color moreno y escaso cabello; a Diógenes, Patita de Garza, por sus escuálidas piernas y a Micaela, una niña que le tiró una tiza la llamó por su fina voz, Paraulata Chillona. Santo Remedio, nadie deseaba ser rebautizado por Wachir. (21)

Este "rebautizo" refleja una inversión del tipo que se expone en el cuento de Simanca Pushaina "Manifiesta no saber firmar. Nacido: 31 de diciembre" y simboliza otro mecanismo de resistencia que se entreteje con la narrativa dentro de estos cuentos incorrectamente clasificados como "infantiles". 


\subsection{El caso del encierro: reverencia y reproche}

En su cuento "El encierro de una pequeña doncella" Simanca Pushaina describe la tradición Wayuu del encierro, una costumbre ancestral de aislar a las jóvenes cuando empieza su primera menstruación. ${ }^{50}$ Mientras que este rito de paso es alabado en el cuento, también aporta asociaciones de dolor-“ ¿Cuánto durará este encierro que me hace sangrar?" (1)-y de tristeza "terminaba llorando la pequeña doncella que aún no comprendía por qué la habían encerrado" (2-3). La joven, Iwa-Kashy, ya ha pasado "treinta lunas" (1) encerrada cuando empieza el cuento. Describe que su madre y unas tías viejas la bañan y la restriegan con hojas, cortándole el cabello "hasta el pegue del cuero" (2). El encierro es también una etapa de purificación; la ermitaña reticente se ve obligada a consumir exclusivamente chicha cerrera o brebajes "para purificar su espíritu y preservar su belleza india" (7). Este rito ancestral, aunque no se lo observa tan estrechamente hoy en día, revela un proceso de honrar a la joven encerrada y su entrada en una nueva etapa de la vida. Tener conocimiento de tales rituales y prácticas, como la de preservar la "belleza india" con brebajes y otros tratamientos naturales, es aún más importante para las jóvenes Wayuu modernas, quienes probablemente no experimentarán este rito de paso. Así, para Simanca Pushaina, dejar este testimonio que honra una práctica tradicional Wayuu es una forma de valorizar su cultura y asegurar la preservación de ella.

En la primera parte del cuento, narrado desde el punto de vista de la doncella encerada, sobresalen las imágenes de brutalidad hacia la inocente: "Quise salir a su encuentro, pero me lo impidió la vieja Yotchón, agarrándome bruscamente por la cintura

\footnotetext{
${ }^{50}$ Refiérase al capítulo 1.2 (Contexto cultural) de este trabajo para más información sobre el encierro. También vale la pena consultar el artículo de Watson-Franke citado en la bibliografía.
} 
y arrojándome al piso de tierra del rancho" (3). Junto a estas descripciones de maltrato, el lector crítico notaría las múltiples referencias al rancho como una cárcel; sólo a través de las rendijas en la puerta logra observar a la gente afuera, y por la noche es limitada a mirar la luna por un hueco en el techo del rancho. En fin, es una desconexión total y abrupta de la comunidad y el ambiente natural que, hasta este momento en la vida de la niña Wayuu, han formado el fundamento de la experiencia y el conocimiento.

Una de las mayores intenciones del encierro es que las mujeres se disciplinen como tejedoras. Como explican Correa y Cardoza, "Ser mujer wayú es ser tejedora en sentido simbólico y material” (2.6.1 s.p.). Al principio del encierro, Iwa es muy consciente de su ineptidud en esta habilidad Wayuu:

[...] las viejas Yotchón y Jierrantá me enseñaban a tejer mochilas, pero debo confesar que mis manos no son como las de la doncella desconocida de la Leyenda de Waleket, la leyenda de la araña, de donde dicen los viejos que los wayúu aprendimos a tejer. Aun no aprendo lo más sencillo y las puntadas se me enredan; si de mi progreso en el tejido dependiera mi salida de este encierro, creo que me quedaría encerrada de por vida. (3)

Las primeras páginas de este cuento ofrecen una imagen de una niña, asustada y confundida, forzada a ocultarse por motivos que son, en esta etapa de su desarrollo, completamente incomprensibles. A pesar de la presencia de ciertos elementos inverosímiles, tales como la araña Waleket que le enseña a Iwa a tejer en sus sueños, no se puede relegar el cuento en el encasillamiento de libros de fantasía, como se lo ha categorizado en el prólogo del libro.

En cambio, este cuento revela varios aspectos la realidad ancestral de los Wayuu y las creencias espirituales y míticas que este grupo indígena mantiene, ya no tanto en la práctica diaria, pero como herencia cultural. Según explica Ana Mejía Patiño, esta misma 
escena se presta a un análisis más profundo: "Sin embargo, mientras Iwa-Kashí aprende a tejer, parece no sólo la araña que teje una red, sino también la presa que ha caído en la red de una araña; en este caso, la red es la tradición misma, que se manifiesta en el encierro físico" (392). A diferencia de Mejía Patiño, considero que este cuento honra la práctica del encierro; aunque la niña sí se siente confundida al iniciar el proceso, pronto se acostumbra y entiende que su clausura tiene motivos más allá de su comprensión. En contraste con lo que se ve en un cuento como "Esa horrible costumbre de alejarme de ti", en el cual la madre mantiene que el abandono es "por tu bien" (54), las mujeres mayores que participan en el encierro, aunque podrían decir lo mismo, dejan que el ritual tenga su efecto "mágico" en la niña. Con el tiempo, la joven sí se transforma: “[...] había dejado atrás a la niña gordita de cara de luna, para darle paso a la majayut, señorita, que había despertado en el encierro" (12). Mientras señala una transformación física, el encierro también ofrece a la joven encerrada el tiempo y el espacio privado para instruirse en las habilidades determinadas las "fundamentales" para las mujeres Wayuu.

Cabe destacar que al final del cuento, cuando la narradora omnisciente se revela como testigo y buena amiga de la niña encerrada, aquélla sella la historia relatando el destino de su querida amiga después de pasar por el encierro. Así el lector, como si estuviera participando de un diálogo íntimo y familiar, aprende que Iwa llegó a tener una vida muy exitosa:

Aún conservamos gran amistad que se inició en Uribia en 1944 [...]. IwaKashy ha sido en dos oportunidades alcaldesa de un importante municipio del departamento de la Guajira. Vive en Maracaibo (Venezuela) y es madre de cinco hijas, una de ellas, Aratmianat, heredó las virtudes artesanales de Iwa y, es diseñadora textil. (16)

Con esta conclusión se nota varias ideas y nociones interesantes; primero, el lector puede 
confirmar la función didáctica de esta historia al percibir la naturaleza oral del cuento.

Fácilmente se puede imaginar que lo acaba de experimentar es una historia que nos está contando una madre o abuela; como describe Patiño Mejía en su reseña de los cuentos de Simanca Pushaina, "Tal procedimiento narrativo exalta la importancia que tiene la palabra hablada para los Wayuu y rememora, a su vez, la dimensión didáctica ancestral del relato" (395). Simultáneamente, hay que captar que este último mensaje también contiene otra noticia importante; que sí es posible ser indígena y moderna a la vez. El personaje principal, Iwa, ofrece un buen ejemplo como evidencia de ello; a pesar de pasar por el encierro (tradición ancestral que va, según algunas percepciones, en contra de la modernidad) y ser madre de muchas hijas, todavía es capaz de convertirse en una líder y participar en la gobernación.

Aunque el relato termina con un mensaje esperanzador, el lector nota la actitud casi nostálgica de la narradora quien reconoce que ya no se aprecia la práctica ancestral del encierro como antes: "Sé que les pudo parecer riguroso el encierro de Iwa-Kashy, pero a mí me hubiera gustado pasar por "el encierro"” (16). Se toma por entendido que aquí el "les" al que refiere la narradora quiere señalar "a ustedes", es decir, a los lectores modernos, sean del pueblo Wayuu o no. Simanca Pushaina confirma que escribió el relato para dejar algún recuerdo escrito de un ritual que ya no forma parte de la transición de niña a mujer:

[Escribí el cuento] para mí, porque yo no pasé por el encierro, quise recrear el mío a través de las diferentes historias de mujeres Wayuu que sí pasaron por él. También lo hice pensando en los niños de mi comunidad, en especial las niñas. El encierro es un ritual de paso que no se practica desde hace algún tiempo. Quise dejar un testimonio escrito para ellas. (Entrevista personal) 
El texto de Simanca Pushaina exalta-“haber pasado por 'el encierro' la hace especial”-a la vez que reconoce, desde una perspectiva moderna, algunos aspectos implacables del rito tradicional (16). Lo que queda claro es que este cuento, a pesar de todo que señala que pertenece al género infantil-el prólogo, el diseño de la portada, las ilustraciones, los personajes, la presencia de elementos mágicos y míticos-se abre a diversos niveles de interpretación que intensifican su valor literario. Es más, la función didáctica no se limita a los lectores jóvenes; el texto ofrece una oportunidad para entrever una práctica cultural ancestral a qué pocos tiene acceso.

Junto con las múltiples críticas hacia la cultura y sociedad hegemónicas de Colombia, las escritoras Wayuu exhiben asimismo, sin idealizar, las imperfecciones de su propia cultura. También analizan algunos aspectos tradicionales cuya función (o practicidad) habrá que reevaluar en la sociedad moderna. Rocha Vivas explica que las obras de Simanca Pushaina no representan una "literatura indigenista que exalta lo indígena, [sino] es una literatura indígena que ocupa un lugar especial, pues no idealiza ni rechaza su mundo, sino que lo revela en un lenguaje interiorizado, poético y con permanentes marcas de la oralidad" (Palabras mayores 196). En el relato "El encierro de una pequeña doncella", se percibe una pérdida total de control cuando Iwa, convertida en una agente completamente pasiva, no tiene alternativa sino dejarse llevar por el ímpetu de los ancestros y la tradición Wayuu: "Iwa era conducida por su madre al interior del rancho" (1). El cuento empieza con un mensaje de confusión y frustración: "Llevo treinta lunas tratando de aprender lo que mamá y las viejas Yotchón y Jierrantá me enseñan” (1) en el cual se subrayan que son los demás, las fuerzas exteriores, que imponen sus exigencias sobre ella-"lo que han hecho" (1)-sin que le expliquen su significado ni el 
propósito de todo el rito.

En cambio, el cuento "No he vuelto a escuchar los pájaros del mundo" por Siosi Pino desarrolla una crítica más abierta y evidente. En este relato, la autora explora las implicaciones posteriores y negativas del encierro en la vida de una joven Wayuu. El relato describe el destino incomprensible de una niña Wayuu que se ve obligada a casarse con un hombre mayor en cambio de una dote: "El día que lo conocí, allá adentro todo se volvió hielo. Me fui con él a una ranchería nueva y esa noche un hombre de medio siglo se posó sobre mis catorce lluvias. El hombre resopló, resopló, resopló y allá adentro sentí caer en un abismo sin fin" (97-98). Aunque quiere huir y regresar a la ranchería de su madre, no lo hace, a sabiendas de que "mil espíritus mugiendo leyes antiguas se sentaban frente a [ella]" (98). Una vez más, se nota una clara discordancia entre los temas de los escritos y lo que típicamente se espera de un cuento infantil. Además, las ilustraciones en esta sección del libro sugieren la misma disconformidad. ${ }^{51}$ El inicio de esta narrativa describe la maldición inminente que la niña, a despecho de su falta de madurez física y emocional, ya intuye:

Una noche sentí la tibieza de la primera menstruación empapando mis muslos y tuve ganas de llorar. Desde ese momento y durante un año dormí sola en el rancho de mi abuela bebiendo las aguas depurativas de la piche y comiendo mazamorra. Esta etapa de mi vida me colmó de gracia, todos lo decían. Intuía que pronto me casaría, pero allá adentro deseaba seguir acompañando a mamá a sacar agua de las cacimbas, caminar con mis primas recogiendo cerezas, ir a los bailes vestida de rojo y mirar sin cansarme el cielo sin nubes de un desierto encandelillado. (Dulce corazón 97).

En este caso, Siosi Pino narra la vida que le espera a una niña después de la etapa del encierro y, a diferencia que la conclusión del cuento de Simanca Pushaina, la encuentra

${ }^{51}$ Refiérase a figura 6 (página 43) de esta tesis. 
llena de tristeza y dolor. Entre todos los cuentos analizados, este es seguramente el que menos pertenece a la categoría de literatura infantil. En el desenlace de este cuento la narradora sigue detallando las múltiples desgracias que constituyen su vida-la borrachera del esposo, el hambre, tres embarazos, la pérdida total de la belleza de su juventud-hasta que el cuento concluye en un triste episodio de frenesí, representando la ruptura final con toda posibilidad de reparación y de esperanza. "No he vuelto a escuchar los pájaros del mundo" revela una fuerte crítica dirigida a los propio Wayuu. Junto con las intenciones de honrar y valorar las tradiciones y prácticas ancestrales de su cultura, Siosi Pino y Simanca Pushaina presentan asimismo los defectos de la misma. 


\section{Capítulo 4 \\ A modo de conclusión}

Como intenta demostrar este trabajo, la literatura indígena colombiana, y en particular la Wayuu, ofrece un nivel de complejidad artística y temática que no ha sido ampliamente reconocido. Después de varios siglos de opresión, marginalización y depreciación por parte de la sociedad hegemónica, se puede percibir que actualmente la literatura indígena latinoamericana sí está experimentando de algún modo un “nuevo amanecer". Lo interesante de esta literatura emergente se halla en que esta nueva etapa no se define por una reivindicación de los valores/producciones artísticas de las poblaciones indígenas del pasado. La literatura contemporánea no busca idealizar ningún estado puro perdido ni intenta resucitar las costumbres y prácticas tradicionales. En cambio, esta nueva tendencia señala más bien una evolución en las culturas indígenas y esta transformación se ve reflejada en las obras de sus escritores. En este sentido, lo que se puede apreciar en la literatura indígena, que sigue desarrollando y floreciendo en la actualidad, es su conexión con la realidad indígena moderna, lo que es, en su mayor parte, una realidad mestiza.

En esta tesis sugiero que la clasificación de las obras literarias de Vicenta Siosi Pino y Estercilia Simanca Pushaina en el género de la literatura infantil señala una incongruencia que puede socavar la recepción de su mensaje, además que representa una nueva manifestación del antiguo tropo colonial que minimiza e infantiliza a las poblaciones indígenas. A través de los paratextos que acompañan a los textos, algunos aparentes y otros más sutiles, se corrobora esta colocación en el género infantil. De este modo el género y los paratextos directamente perjudican, o por lo menos dificultan, la 
incorporación de dichas obras en el mundo de literatura "seria". Al mismo tiempo, busco revelar con esta tesis que ambas escritoras aprovechan de este símbolo, invirtiéndolo y manipulándolo hasta que adquiere otro significado: uno renovado, mestizo, y propiamente suyo. Las obras de ambas autoras demuestran una técnica ingeniosa de subvertir las expectativas; en sus textos se puede vislumbrar una verdadera crisis de identidad, tanto individual como colectiva, que bajo una cubierta de "inocencia" parece no concordar. Es más, sus personajes más desarrollados - los niños, sobre todo las niñas - son también los más sagaces en todos los cuentos analizados, hecho que alude a las posibilidades de otra realidad y promueve un diálogo intercultural. La esperanza que impregna las obras de ambas autoras es innegable, a pesar de una temática difícil que denuncia abiertamente los abusos, las condiciones y las injusticas generales que los Wayuu sufren diariamente.

Considerando específicamente la sociedad Wayuu y su estimación mítica del poder de la palabra, no sorprende que las dos escritoras Wayuu hayan escogido la palabra escrita como herramienta para conseguir la justicia. A pesar de la tradición Wayuu de los palabreros, y la autoridad que se confiere a la palabra hablada en su cultura, podemos tomar este nuevo énfasis en la escritura como una evolución moderna del mismo poder; esta vez, canalizado a través de la palabra escrita. Aunque las instancias de mujeres palabreras en las comunidades Wayuu son escasas, fácilmente se puede sostener que la narrativa de ambas autoras contiene ciertas técnicas que los palabreros utilizan para mejor transmitir su mensaje. El formato del cuento le permite a las autoras a aplicar su propio "despliegue retórico", frase utilizada por Weilder Guerra Curvelo para describir lo que exhiben los pütchipü' üi (palabreros Wayuu) cuando inician el proceso reconciliatorio 
(127). Con la implementación de un lirismo casi infantil, casi como si fuera una canción de cuna, Simanca Pushaina y Siosi Pino logran cautivar a su público con un cuento agradable y humorístico mientras realizan otro objetivo en el desarrollo de una crítica aguda y eficaz. Así transforman la dulzura e inocencia de un cuento infantil para reafirmar su denuncia de las injusticias sufridas por los Wayuu a manos del Estado colombiano y de la cultura hegemónica.

Aunque tradicionalmente la oralidad puede señalar una negación de la palabra escrita, la literatura de Siosi Pino y Simanca Pushaina no revela una paradoja sino una inversión de estas asunciones del pasado. Es más, Simanca Pushaina ha expresado la aspiración de que sus cuentos lleguen a transmitirse entre los Wayuu como cuentos orales; esta autora continúa la resistencia y su denuncia a través de la escritura para que “el mito del conquistador conquistado sea una realidad cuando todos hablen y cuenten Manifiesta no saber firmar. Se trata de revertir el proceso, ir de lo escrito a lo oral" (Duchesne Winter 321). Las obras de las dos autoras Wayuu reflejan una nueva realidad en la que lo oral y lo escrito pueden fundirse de forma natural; en este mundo no es necesario erradicar nada, ni a nadie, para que el otro pueda existir. Así también las autoras comentan sus esperanzas para la inclusión pacífica y el tratamiento equitativo de los indígenas dentro de la cultura dominante.

Los Wayuu siempre han sido un pueblo propenso a modificaciones y evoluciones, en gran parte por su contacto con otras culturas. En un documental llamado Palirawaa una unión Wayuu - Arijuna, Guerra Curvelo explica que los Wayuu son receptivos a innovaciones, "los cuales ellos filtran, seleccionan aquellas que les sirven, aquellas que no les sirven [...] Los Wayuu son dinámicos; están cambiando. Lo que importa, lo que 
hace que un pueblo sea auténtico, [...] es la capacidad creativa" (min. 14:03). Es precisamente esta estrategia de transculturación que utilizan las dos escritoras Wayuu en sus cuentos; una fusión única de lenguajes, estilos, y conceptos que revela un reciclaje de materiales e ideas que lógicamente surgen de su experiencia mestiza. Su posición única como mujeres mestizas no limita el acceso a los dos universos-el dominante y el indígena - sino el contrario: les brinda paso a múltiples puertas de posibilidad. Siosi Pino y Simanca Pushaina ofrecen a sus lectores un torbellino de elementos revueltos, inspirados y prestados de una multitud de fuentes. Tal tejido de elementos puede llevar a cierta incertidumbre y hasta confusión desde una perspectiva hegemónica. Sin embargo, este revuelo es quizás menester para lograr invertir, y eventualmente erradicar, los vestigios del pasado colonial con el fin de realizar ese anhelado ambiente intercultural en el cual es posible realizarse como indígena e individuo moderno al mismo tiempo. 


\section{Obras citadas}

Anderson, Benedict R. Imagined Communities: Reflections on the Origin and Spread of Nationalism. London; New York: Verso, 1991. Impreso.

Beverley, John. “The Margin at the Center: On Testimonio (Testimonial Narrative)”. The Real Thing: Testimonial Discourse and Latin America. Ed. Georg M. Gugelberger Durham: Duke UP, 1996. 23-41. Impreso.

Bourdieu, Pierre. The Field of Cultural Production: Essays on Art and Literature. New York: Columbia UP, 1993. Impreso.

Bravo Mendoza, Víctor. Cuentos. Riohacha, La Guajira: Ministerio de Cultura, 2007. Impreso.

---. $\quad$ Cuentos de autores guajiros 2. Bucaramanga, Colombia: Editorial Libertad, 1995. Impreso

---. La Guajira En Su Literatura. Colombia: Beca Fondos Mixtos, 1997. Impreso.

Cardozo, Socorro Vásquez y Hernán Darío Correa C. "Los Wayuu, entre Juya ("El que llueve"), Mma ("la tierra") y el desarrollo urbano regional". Geografía Humana de Colombia. Nordeste Indígena. Tomo II. Bogotá: Instituto Colombiano de Cultura Hispánica, 2000. Web. 31 enero 2016.

"Cerrejón pospone estudios sobre la posible desviación del río Ranchería". El espectador 8 noviembre 2012: sin pág. Web. 13 marzo 2016.

Chandler, Daniel and Rod Munday. "High culture". A Dictionary of Media and Communication. Oxford University Press, 2011. Web. 9 marzo 2016.

Collazos, Oscar. ¿Qué es la colombianidad?”Semana 12 noviembre 1980: sin pág. Web. 7 abril 2016.

Comisión Nacional de Reparación y Reconciliación, grupo de Memoria Histórica. La masacre de Bahía Portete: Mujeres Wayuu en la mira. Bogotá: Taurus, 2010. Impreso.

Conor, Liz. “The 'Piccaninny': Racialized Childhood, Disinheritance, Acquisition and Child Beauty". Postcolonial Studies 15.1 (2012): 45-68. PDF.

Constitución política de Colombia 1991. Procuraduría General de la Nación. Web. 3 febrero 2016. 
Cornejo Polar, Antonio. Escribir en el aire: Ensayo sobre la heterogeneidad sociocultural en las literaturas andinas. Lima: Editorial Horizonte, 1994. Impreso.

Cortez, Enrique E. "José María Arguedas y el concepto de experiencia". Taller de letras 51 (2012): 101-113. PDF.

Cosoy, Natalio. "Colombia's Alta Guajira region struggles with drought". BBC Mundo 12 octubre 2015: sin pág. Web. 23 abril 2016

De Barranquilla, José Agustín. Así es la Guajira. Barranquilla: Emp. Litográfica, 1946. Impreso.

De la Cadena, Marisol y Orin Starn. "Indigeneidad: Problemáticas, experiencias y agendas en el nuevo milenio" Tabula Rasa 10 (2009): 191-223. Web. 22 abril 2016 .

De la Hoz Simanca, Jaime. "Vicenta Siosi Pino debió heredar el apellido Apshana. Los wayuu tienen su propia escritora." Letralia 212 (junio 2009): sin pág. Web. 16 diciembre 2015.

Deleuze, Gilles and Félix Guattari. "What is Minor Literature?" Falling into Theory: Conflicting Views on Reading Literature. Ed. David H. Richter. Boston: Bedford of St. Martin's, 1994. 166-172. Impreso.

Devitt, Amy J. Writing Genres. Carbondale: Southern Illinois UP, 2004. Impreso.

Duchesne Winter, Juan. Hermosos invisibles que nos protegen: Antología Wayuu.

Pittsburgh: Instituto Internacional de Literatura Iberoamericana, 2015. Impreso.

"El sistema normativo de los wayuus, aplicado por el pütchipü'üi ('palabrero')". UNESCO. Web. 15 febrero 2016.

"En 2015 van 808 niños muertos por inanición y desnutrición, según comisión del Senado”. Redacción Vivir. El espectador 10 diciembre 2015: sin pág. Web. 14 marzo 2016.

Frow, John. Genre. 2a edición. Abingdon; NY: Routledge, 2015. New Critical Idiom. Ebook. Web. 9 marzo 2015.

Genette, Gérard. Paratexts: Thresholds of Interpretation. Cambridge; New York: Cambridge UP, 1997. Impreso.

Giraldo, Eduardo. "La frontera invisible del territorio Wayúu". Transpasando Fronteras 1 (2011): 53-64. Web. 11 mayo 2015. 
Guerra-Cunningham, Lucía. "Las sombras de la escritura". Cultural and Historical Grounding for Hispanic and Luso-Brazilian Feminist Literary Criticism. Ed. Hernán Vidal. Minneapolis: Inst. for Study of Ideologies \& Lit.,1989. 129-164. Impreso.

Guerra Curvelo, Weildler. La disputa y la palabra: la ley en la sociedad wayúu. Bogotá: Ministerio de Cultura, 2002. Impreso.

Hernández Rincón, Mauricio. Portada. El encierro de una pequeña doncella. Ilustración. Comfamiliar del Atlántico. Web. 24 abril 2016.

Krebs, Nina. Edgewalkers: Defusing Cultural Boundaries on the New Frontier. Liberty Corner, NJ: New Horizon, 1999. Impreso.

"La Carta de una escritora wayuu a Santos". Redacción vivir. El espectador 13 abril de 2012: sin pág. Web. 21 octubre 2015.

Lanao Loaiza, José Ramón. Las pampas escandalosas. Manizales, Colombia: A Zapata, 1936. Impreso.

Landaburu, Jon. "La situación de las lenguas indígenas de Colombia: prolegómenos para una política lingüística viable". Amérique Latine Histoire et Mémoire. Les Cahiers 10 (2004): sin pág. Web. 3 febrero 2016.

Máynez, Pilar. "Visión de los vencidos, a cincuenta años de su publicación”. Estudios de cultura Náhuatl 40 (2009): 395-400. Web. 16 abril 2016.

Menchú, Rigoberta y Elisabeth Burgos-Debray. Me llamo Rigoberta Menchú y así me nació la conciencia. México: Editores Siglo Veintiuno, 1985. Impreso.

Metz-Cherné, Emily. Inconceivable Saviors: Indigeneity and Childhood in U.S. and Andean Literature. Tesis doctoral. Universidad de Pittsburg, 2013. ProQuest Dissertations and Theses. PDF.

Ministerio de Educación Nacional. Anaa Akua'ipa: Proyecto etnoeducativo de la nación wayиu. Bogotá: 2009. Web. 15 febrero 2016.

Orrego Arismendi, Juan Carlos. "El indio animal en dos novelas de Francisco Leal Quevedo". Estudios de Literatura Colombiana 32.1 (2012): 121-136. Web. 6 noviembre 2015.

Patiño Mejía, Ana Mercedes. "Las cuentistas de hoy en La Guajira, San Andrés y 
Providencia y El Choco”. Estudios de Literatura Colombiana 21 (2007): 149. Web. 21 julio 2015.

---. Reseña. "Simanca Pushaina, Estercilia. El encierro de una pequeña doncella. Maicao: Centro Educativo Indígena Regional. Alcaldía Municipal de Maicao. Fundación Manifiesta No Saber Firmar, 2006, 50 págs.” Inti: Revista de literatura hispánica 1.63 (2006): 391-396. Web. 21 febrero 2016.

Pérez van-Leenden, Francisco Justo. Prólogo. El dulce corazón de los piel cobriza. Barranquilla: Fondo Mixto para la Promoción de la Cultura y las Artes de la Guajira, 2002. Impreso.

--- "Wayuunaiki: Lengua, sociedad y contacto". Lenguas Amerindias: Condiciones sociolingüísticas en Colombia. Eds. Ximena C. Pachón y François Correa. Bogotá: Instituto Colombiano Antropología, 1997. Impreso.

Perrin, Michel. Introducción. Folk Literature of the Guajiro Indians. Vol. 1. Eds. Johannes Wilbert y Karin Simoneau. Los Angeles: UCLA Latin American Center, 1986. Impreso.

---. $\quad$ The Way of the Dead Indians: Guajiro Myths and Symbols. Trans. Michael Fineberg. Austin: UT, 1987. Impreso.

Pratt, Mary Louise. “Arts of the Contact Zone”. Profession (1991): 33-40. Web. 27 enero 2016.

Quintero, María Clara. "Documental: Palirawaa una unión Wayuu - Arijuna”. Documental en línea. YouTube. YouTube, 25 mayo 2015. Web. 5 marzo 2016.

Rappaport, Joanne. Intercultural Utopias: Public Intellectuals, Cultural Experimentation, and Ethnic Pluralism in Colombia. Durham, N.C.: Duke UP, 2005. Impreso.

Retamar, Roberto Fernández. “Calibán: Apuntes sobre la cultura de nuestra América”. México: 1971. Web. 11 noviembre 2015.

Rico Torres, Alonso. "Las cédulas de la burla wayuu”. El espectador 12 septiembre 2011: sin pág. Web. 14 marzo 2016.

Rocha Vivas, Miguel, comp. Antes el amanecer, antología de las literaturas indígenas de los Andes y de la Sierra Nevada de Santa Marta, Bogotá: Ministerio de Cultura, 2010. Impreso.

---. $\quad$ comp. El sol babea jugo de piña: antología de las literaturas indígenas del Atlántico, el Pacífico y la Serranía del Perijá. Bogotá: Ministerio de Cultura, 2010. Impreso. 
---. $\quad$ Entrevista personal. 17 febrero 2016. Skype.

---. $\quad$ Palabras mayores, palabras vivas: tradiciones mítico-literarias y escritores indígenas en Colombia. Bogotá: Aguilar, 2012. Impreso.

---. $\quad$ comp. Pütchi Biyá Uai: Antología multilingüe de la literatura indígena contemporánea en Colombia. 2 vols. Bogotá: Alcaldía Mayor de Bogotá y Fundación Gilberto Alzate Avendaño, 2010. Impreso.

---. Textualidades oralitegraficas y visiones de cabeza en las oralituras y literaturas indígenas contemporáneas en Colombia. Tesis doctoral. Universidad de Carolina del Norte, Chapel Hill, 2015. Ann Arbor: UMI, 2015. UMI no. 3703911. Web. 23 julio 2015.

Rojas Neira, Rafael. Ilustraciones. El dulce corazón de los piel cobriza. Barranquilla: Fondo Mixto para la Promoción de la Cultura y las Artes de la Guajira, 2002. Impreso.

Romero, Astrid H. La visibilización estadística de los grupos étnicos colombianos. Bogotá: Departamento Administrativo Nacional de Estadística (DANE), 2005. Web. 30 enero 2016.

Sánchez Gutiérrez, Enrique y Hernán Molina Echeverri, comp. Documentos para la historia del movimiento indígena colombiano contemporáneo. Bogotá: Ministerio de Cultura, 2010. Web. 8 febrero 2016.

Schlau, Stacey. Introducción. Spanish American Women's Use of the Word: Colonial through Contemporary Narratives. Tucson: U of Arizona, 2001. Impreso.

Simanca Pushaina, Estercilia. El encierro de una pequeña doncella. Barranquilla: Comfamiliar del Atlántico, 2003. Impreso.

---. Entrevista personal. 12 enero al 16 marzo 2016. Correo electrónico.

---. Manifiesta no saber firmar. Nacido: 31 de diciembre”. El sol babea jugo de piña: antología de las literaturas indígenas del Atlántico, el Pacífico y la Serranía del Perijá. Eds. Miguel Rocha Vivas y María Villa Lagarcha. Bogotá: Ministerio de Cultura, 2010. Web. 7 de mayo de 2015.

---. Manifiesta no saber firmar. Nacido: 31 de diciembre”. La Guajira: edición de la autora, 2006. Impreso.

Siosi Pino, Vicenta María. El dulce corazón de los piel cobriza. Barranquilla: Fondo Mixto para la Promoción de la Cultura y las Artes de la Guajira, 2002. Impreso. 
Trino Morales, Manuel. “Cómo nació y qué significa Unidad indígena”. Documentos para la historia del movimiento indígena colombiano contemporáneo. Comp. Enrique Sánchez Gutiérrez y Hernán Molina Echeverri. Bogotá: Ministerio de Cultura, 2010. Web. 8 febrero 2016.

Villegas, María. "Often Difficult, Never Impossible: The Colombian Book Market" Publishing Research Quarterly 31.1 (2015): 64-72. Web. 16 diciembre 2015.

Vizcaíno Escobar, Edén Iván. Mi libro de cultura wayuu. Barranquilla: Casa editorial Antillas, 2010. Impreso.

Watson-Franke, Maria Barbara. "Seclusion Huts and Social Balance in Guajiro Society". Anthropos 77.3/4 (1982): 449-60. Web. 11 enero 2016.

Westman, Karin E. "Beyond Periodization: Children's Literature, Genre, and Remediating Literary History”. Children's Literature Association Quarterly 38.4 (2013): 464-69. Web. 20 febrero 2016. 


\section{Apéndice A - Entrevista personal con Estercilia Simanca Pushaina}

Estas entrevistas tuvieron lugar entre la escritora Wayuи Estercilia Simanca Pushaina y la autora de esta tesis, Lindsay Perwak. La entrevista entera es compuesta de varios correos electrónicos que nos escribimos entre el 12 de enero y el 16 de marzo de 2016. Aparte de contestar a estas preguntas, la autora Wayu me envió muchos cuentos inéditos e ideas para recursos adicionales. Estoy muy agradecida por su generosa colaboración.

Aquí abajo aparecen mis preguntas y las respuestas de Simanca Pushaina en orden cronológico. Como todos fueron correos electrónicos informales, en unos cuantos casos, he corregido la gramática o la puntación para la clarificación.

Lindsay Perwak: ¿Quién aplica la etiqueta "infantil” a los cuentos? ¿Usted quería escribir cuentos para niños o es que las casas editoriales describieron sus obras así? (Pienso en el prólogo de su cuento El encierro de una pequeña doncella de Comfamiliar del Atlántico) ¿Cuáles fueron sus intenciones al iniciar la escritura?

Estercilia Simanca Pushaina: Lo hice para mí, porque yo no pasé por el encierro, quise recrear el mío a través de las diferentes historias de mujeres Wayuu que sí pasaron por él. También lo hice pensando en los niños de mi comunidad, en especial las niñas. El encierro es un ritual de paso que no se practica desde hace algún tiempo. Quise dejar un testimonio escrito para ellas.

Lo envié a un concurso de literatura infantil para ver qué tan universal podía ser mi cuento. Qué aceptación podría tener un tema como la primera menstruación en un concurso infantil y más si había un ritual de por medio. No gané pero sí recomendaron la publicación. Lo hicieron y me incluyeron en la lista de honor IBBY entonces sí comprobé que era muy, pero muy universal.

Mis intenciones siempre serán dejar testimonios de todo lo que veo. Memoria utilizando el lenguaje para conservar el pasado.

LP: ¿Quién es el público que más lee sus cuentos - colombianos en general, wayúu, internacional, etc? ¿Para quiénes escribe usted?

ESP: Todos los anteriores menos los Wayuu. Hay mucho analfabetismo y desinterés también. Cuando un Wayuu me lee no se asombra. Quienes han podido leerme dicen: "Eso le pasó a mi abuela". Yo le escribo al mundo.

LP: ¿Dónde y cómo apareció la primera edición [del cuento Manifiesta no saber firmar, Nacido: 31 de diciembre]?

ESP: Esa también la financié yo y con un aporte muy pequeño de una entidad cultura de aquí de la Guajira Fondo Mixto para la Promoción de La Cultura y la Artes de La Guajira 
en el 2005. Cuando supe cuánto era el aporte del fondo decidí definitivamente financiarla. Esperar algo más significativo no iba a suceder por eso lo hice. Siempre la imagine en formato de revista o folleto porque así llamaría más la atención.

LP: ¿Usted habla Wayuunaiki?

ESP: No hablo en Wayuunaiki.

LP: ¿Qué opinión tiene acerca de publicar en español vs. en lenguas nativas?

ESP: No me llama la atención pero obedece más a políticas públicas que a mis deseos como autora.

LP: ¿Qué le pareció la traducción que hizo José Ángel Fernández Wuliana de su cuento "Manifiesta no saber firmar” en la antología de M. Rocha Vivas Pütchi biyá uai? ¿Usted cree que esta traducción logró llegar a más lectores wayuu?

ESP: La traducción hacia parte del proyecto, fue editado y publicado en Bogotá. Que se haya traducido no logró llegar ni a un tercio de la población Wayuu, ni a lectores del Pueblo Wayuu, cuando aprenden a leer y escribir en español leen en español si hay textos en Wayuunaiki puede que lo lean, la verdad es que quien lee en Wayuunaiki es porque sabe leer y escribir en español, aquí hay mucho analfabetismo.

LP: Muy bien, entonces, ¿cómo se podría llegar a los wayuu a través de la literatura (sea escrita u oral)?

ESP: Es muy difícil eso sabes, porque al Wayuu que tiene la oportunidad de leer no le gusta hacerlo. Algo que tengo en mente es hacer audios de mis cuentos y también de las leyendas y mitos Wayuu completamente en Wayuunaiki, narrados obviamente por un hablante. Aquí en mi tierra y a través de mi profesión he iniciado y culminando procesos que tienen que ver [con] la identidad Wayuu[;] exijo que haya traductores en las instituciones públicas y privadas, exijo que hasta las razones sociales de las entidades estén escritas en fonemas Wayuu, de hecho ese será mi próximo paso a seguir, ejercer la oficialidad del idioma Wayuu en el departamento de La Guajira, yo no lo hablo, no importa, pero hay muchos Wayuu que no hablan español y necesitan hacer sus trámites, es necesario y yo tengo las herramientas para que sea una realidad.

LP: ¿Cree usted que la literatura es importante para los wayuu?

ESP: No. No es importante. Pese a que por medio de nuestros textos saben de nosotros, pero la verdad no reviste mayor importancia en la población. Hay asuntos por resolver antes de sentarse a escribir o leer.

LP: ¿Cree que los cuentos (más conectados con la tradición de contar o transmitir historias) son más accesibles que las novelas, en su opinión? 
ESP: Eso es relativo, en los cuentos puedes narrar algún elemento de la cultura, por ejemplo del encierro, de la identidad, del arraigo o del desarraigo, pero en una novela puedes involucrar todos esos elementos.

LP: Hablé anoche con Miguel Rocha Vivas y tuvimos una muy buena conversación acerca de sus cuentos y los de Vicenta Siosi. Él me dijo que usted había negado publicar un libro de sus cuentos hace poco, prefiriendo mantener su blog. ¿Puede comentar un poco sobre esta decisión? ¿Qué opinión tiene acerca del sistema editorial en Colombia? ¿Sobre la disponibilidad y la circulación de sus obras publicadas?

ESP: Te contaré mi versión. A mi [me] contactó una editora amiga de Miguel Rocha, interesada en mis cuentos, se los envíe, pero no satisfacía lo que deseaba la editorial en número de hojas, mis cuentos son cortos porque la realidad de nosotros es muy puntual, el hilo conductor es corto, yo escribo como hablo y no tengo afán en publicar. Si el número de hojas no es lo atractivo de malas, prefiero seguir publicando en mi blog. Mi negativa fue cuando me propuso de integrar mis cuentos con otros autores indígenas del Sur del País, yo estoy en la lucha de ser reconocida como escritora, no como escritora indígena, la literatura no tiene jurisdicción. La indígena soy yo.

LP: Algo más en cuanto al estilo - ¿usted cree que debería escribir wayuu con W mayúscula? He visto wayuu, wayú, wayúu, Wayuu - hay muchas formas.

ESP: Ahí si nunca nos vamos a poner de acuerdo. Yo acepto hasta que escriban Guayú, waiü. Es la locura con los Wayuu, somos el Pueblo más desunido porque no nos ponemos de acuerdo en nada. Pero en lo particular yo escribo Wayuu ya las tildes que se las coloquen.

LP: Me han dicho que los alumnos estudian sus cuentos (junto otros de autores Wayuu, incluyendo las de Vicenta Siosi) en los colegios de la Guajira. ¿Esta práctica se extiende a otras regiones del país? ¿Forman parte de algunos cursos universitarios también? (Ya me ha dicho Miguel Vivas que, en su caso, los incorpora en su plan de estudios, pero no sé qué tan común es).

ESP: En los colegios sí, en la universidad también, pero no hay una cátedra, sí la hubo y la manejaba Vicenta Siosi pero ella ya no está en la Universidad. Nos invitan porque el profesor de literatura nos conoce o nos ha leído y porque en mi caso particular promociono mi blog a través de las redes y tengo mucho seguidor joven. Pero incorporados en el plan de estudio no, más bien como actividades extracurriculares.

LP: ¿Por qué prefiere usted el uso de niños/niñas como personajes principales? ¿Qué ofrecen a la narrativa?

ESP: Porque son los únicos que pueden ofrecer preguntas inocentes para respuesta[s] obvias y que los adultos ya no percatamos. Porque si un niño o niña es el que hace la 
crítica es más reflexivo ya que todos mis textos llevan implícita una crítica al sistema y también a los usos y costumbres. Porque por lo general quien me lee no es de mi Pueblo y esas son las preguntas que siempre se plantean.

LP: ¿Cree que sus cuentos deberían ser clasificados como literatura infantil? ¿Qué ventaja o desventaja trae su colocación dentro de este género?

ESP: No deberían ser clasificados como infantiles la verdad, pero si eso es lo que cree el público lector yo los dejo, considero que la literatura no tiene jurisdicción ni edad. Si por mi fuera yo colocaría "Apto para todo público".

LP: En cuánto al género literario y la clasificación de obras en un esquema definido ¿Qué pasa, por ejemplo, con un cuento/ensayo como "Manifiesta"?

ESP: Yo lo clasifico como cuento. Hay gente que cree que son sucesos que me pasaron a mí y lo ubican en relato. Pese a que manifiesta es basado en hechos reales tiene un poco de la realidad de gente que conozco. Así como en [el] encierro, un poco del encierro de varias mujeres Wayuu.

LP: ¿Todavía es muy común la poligamia y los dotes o pago por contraer matrimonio?

ESP: Sí.

LP: ¿Qué piensa usted sobre estas prácticas como mujer Wayuu moderna?

ESP: Nunca he estado de acuerdo. Pienso que la mujer debe ser libre en aceptar o no a un pretendiente. La rechazo de plano cuando el pretendiente es muy mayor que la mujer. En el pasado estuvo quizás estuvo bien porque la dote tiene su razón de ser. Pero lo que yo veo en algunas familias Wayuu es la venta pura y simple de la niña, no una dote como tal.

LP: Hoy en día, ¿cómo se definen los papeles de género en la sociedad Wayuu? ¿Cuál es la posición social - oportunidades o limitaciones - de la mujer Wayuu en la comunidad?

ESP: No tengo respuesta para eso. Ya esa pregunta es muy antropológica. Yo te puedo decir que la mía es privilegiada por mi entorno, mi realidad con respecto a la de muchas mujeres Wayuu de mi edad que no pudieron estudiar o simplemente no quisieron. Hay mujeres Wayuu de 40 años que ya tienen nietos y han parido 10 veces. Derivan su sustento de la artesanía u otras actividades.

LP: Sé que usted diseñó la portada de su cuento "Manifiesta no saber firmar" en varias ediciones. ¿Qué fue su rol, si lo hubo, en diseñar la portada del libro El encierro (edición de Comfamiliar del Atlántico, con la ilustración por Mauricio Hernández Rincón). Sigo aclarando algunas teorías acerca del encasillamiento de sus textos dentro del género de literatura infantil. 
ESP: A mí me dijeron que me publicarían el libro, meses después me invitaron a conocer el libro ya hecho. A Mauricio lo conocí en el lanzamiento, en Riohacha.

LP: Viendo el libro de El encierro de nuevo, noté que aparece su biografía así:

“Abogada. Nació el 10 diciembre de 1975 en la Ranchería Indígena Wayúu El Paraíso, Resguardo Indígena de Caicemapa, Municipio de Distracción (Baja Guajira)”. ¿Usted escribió esta corta biografía o fue el editorial Comfamiliar?

ESP: Fui yo. No tenía nada más que agregar.

LP: Además, veo que se escribió su apellido Simanca con una "s" (Simancas) por todo el libro y que eliminaron Pushaina en la portada y al interior de la tapa. ¿Qué opina? ¿Le molestó que no incluyeran el nombre de su clan en la portada?

ESP: $\mathrm{Si}$, a veces lo escriben así con $\mathrm{S}$ al final. No, no me molestó para nada. No le presté atención. 


\section{Apéndice B - Carta de Vicenta Siosi Pino al presidente Santos}

Doctor Juan Manuel Santos. Presidente de la República de Colombia. Respetuoso saludo. Le escribo desde Pancho, una aldea wayuu con casas de barro y techos de zinc, que se levanta en la margen derecha del río Ranchería, el único río de la Media y Alta Guajira.

Decenas de rancherías circundan Pancho porque los wayuu vivimos diseminados por este desierto que Dios nos dio.

Las gentes por aquí viven de la pesca. Aún los niños capturan lizas, bagres, bocachicos y camarones que son nuestro alimento. Las mujeres recogen cerezas, iguarayas, mamoncillos cotoprix, coas silvestres para venderlas.

El otoño, con sus truenos escandalosos nos avisa de las lluvias, y se preparan las huertas para el frijol, la patilla, la auyama y el maíz. Recoger la cosecha es un gozo indescriptible.

Algunos wayuu tienen rosas permanentes junto al río. Con gran esfuerzo, cargan el agua con valdes y riegan mata por mata. Otros toman barro y agua del río para fabricar ladrillos destinados a la construcción de viviendas citadinas.

Como en la orilla del río hay espesa vegetación, un grupo corta las ramas de los árboles de trupillo y hace carbón de madera. No tenemos gas domiciliario, ni estufas eléctricas. Algunos hombres van a la ribera del Ranchería y cazan cangrejos azules para vender sus muelas. Luego los devuelven a sus cuevas.

Criamos chivos, y los rebaños van al río a tomar agua.

El Ranchería es el único río de los wayuu. La única corriente de agua que atraviesa este territorio ancestral. Al río vamos a bañarnos. Es una diversión exultante. Allí̌, los jóvenes se enamoran y fundan lazos de amistad. Las mamas lavan ropa y los pequeñitos aprenden a nadar.

Con el barro blando de las orillas las niñas fabrican muñecas, tacitas y platicos que secan al sol.

En un libro del Cerrejón titulado: 'Resumen del proyecto de expansión para grupos de interés', en su página 60, dice que el cambio climático global (CCG) nos afectaría: 'El clima en la Guajira podría tornarse más cálido y seco, con una disminución en la pluviometría de 5 a $10 \%$. Los glaciales de la sierra nevada de Santa Marta podrían desaparecer hacia el año 2050, lo que afectaría la disponibilidad de fuentes de agua en la región’. ¿Cómo será la vida del wayuu sin el río Ranchería?

A Pancho llegaron el día 28 de marzo de 2012 funcionarios del Cerrejón e informaron a la comunidad que tienen proyectado desviar 26 kilómetros de nuestro río. Advirtieron 
que éste se va a secar en verano y añadieron que posiblemente construyan un embalse en el río Palomino (Barrancas).

Entonces, ¿Cómo nos proveerá’ un arroyo seco?

Anunciaron que los 500 millones de toneladas de carbón bajo el río generarían regalías. En 30 años de explotación del mineral, las regalías del departamento le han servido para nada.

Los hospitales permanecen en paro y la educación ocupa el último lugar del país: según una investigación del Banco de la República el 50\% de los niños wayuu padecen desnutrición. Este año informaron que la Guajira ostenta el más alto nivel de pobreza e indigencia en Colombia, con un 64\%. Veo que las regalías no han ayudado en lo fundamental.

¿Por qué cambiaríamos nuestro único río a cambio de regalías?

Al final de la reunión concluyeron que sería una gran obra de ingeniería y que las cosas seguirían igual. A lo que una jovencita de la comunidad preguntó.

'Si todo permanecerá Igual ¿Por qué nos quieren compensar? Nuestro transcurrir en la península Guajira gira alrededor del río, él es la gracia y la vida aquí'.

Señor Presidente, por favor no permita que la empresa extranjera Cerrejón destruya el acuífero que mantiene el Ranchería y seque la única fuente de agua que poseemos.

Si se licencia el traslado y empezamos a padecer los perjuicios, no podremos volver atrás, el daño es irreversible.

Por favor ayude a los wayuu.

\section{Fuente:}

"La carta de una escritora wayuu a Santos". Redacción vivir. 13 abril de 2012. El espectador. Web. 21 octubre 2015. 